\title{
PROBLEMS OF ENVIRONMENTAL AND NATURAL RESOURCES LAW DEVELOPMENT
}

Collective monograph

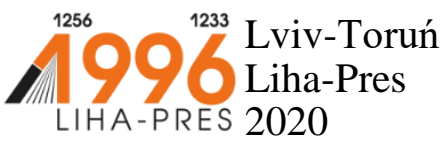




\section{Reviewers:}

Prof. dr hab. Sabina Grabowska, Uniwersytet Rzeszowski / University of Rzeszow (Republic of Poland);

Prof. dr hab. Joanna Marszalek-Kawa, Uniwersytet Mikotaja Kopernika w Toruniu / Nicolaus Copernicus University (Republic of Poland).

Problems of environmental and natural resources law development : collective monograph / V. Kostytsky, G. Balyuk, V. Sydor, V. Yermolenko, etc. ; edited by Prof. V. Kostytsky. - Lviv-Torun : Liha-Pres, 2020. - $136 \mathrm{p}$.

ISBN 978-966-397-205-3

\section{SENSE}

Liha-Pres is an international publishing house which belongs to the category "C" according to the classification of Research School for Socio-Economic and Natural Sciences of the Environment (SENSE) [isn: 3943, 1705, 1704, 1703, 1702, 1701; prefixMetCode: 978966397]. Official website www.sense.nl. 


\section{CONTENTS}

INTRODUCTION ................................................................................ 1

ECOLOGICAL SECURITY: LEGAL CONCEPT,

ATTRIBUTES, CRITERIA AND POSITION

IN THE SYSTEM OF NATIONAL SECURITY

Balyuk G., Kovalchuk T.

THE CONCEPT OF ECOLOGICAL LAW

AND ITS PLACE IN LEGAL SYSTEM

Kostytsky V.

THE PECULIARITIES OF THE STATE REGULATION

OF THE TERRITORIAL INTERCOURSE

IN THE COUNTRIES OF THE COMMONWEALTH

OF INDEPENDENT STATES

Stratonov V. M., Gavlovskaya A. O., Pavlish P. V.

A NEED OF ENVIRONMENTAL LEGAL

FRAMEWORK EVOLUTION

Sydor V. D. .65

THE ENVIRONMENTAL CONTENTS

OF THE RIGHT TO HIGHER EDUCATION

Tymoshenko M., Sukhodolska A

DEVELOPMENT OF SCIENTIFIC OPINION

ON THE FORMATION OF NATURAL

RESOURCES LAW

Yermolenko V. M., Deineha M. A., Kostytska I. O.

LEGAL AND ORGANIZATIONAL SUPPORT

FOR THE LAND REFORM BY THE P. STOLYPIN

GOVERNMENT

Zakharchenko P. P. 


\section{INTRODUCTION}

Environmental law is one of the most dynamic sciences nowadays, which is objectively conditioned by the increasing environmental challenges that confront the current civilization. We consider the response to these challenges to be an important element of both the planetary-scale ecological disaster prevention and the attempt to elaborate mechanisms to address other global, regional and local environmental problems.

In his previous works the author has already noted that in the coming years a significant increase in Ukraine's international commitments is expected, since there is a number of international conventions, accession to which (as well as the signing of the new ones) would be of considerable political importance for Ukraine and would increase the opportunities for exploitation and reproduction of natural resources.

In such circumstances, it is necessary to increase the effectiveness of legal regulation in the field of environmental legal relations and to strengthen the role of the state in solving environmental problems of the modern world. In this regard, peculiar interest is aroused by the studies of the American scholar Th. W. Hoya who concluded based on the analysis of the methods of market economy in American and Russian environmental law that "of all industrialized countries of the West, US environmental law is mostly based on command-and-control methods"1.

At the same time, strengthening the role of the state, both within the country and in the system of international relations, does not mean that the full burden of the transition to sustainable development should be concentrated on the state only, without interaction with the civil society. In modern theory of law and constitutional practice saving the environment for present and future generations is seen as a shared responsibility of the state, the civil society and a human. This approach can be defined as a moral and ethical environmental legal imperative, which is accepted in almost all countries of the world.

Legal scholars are right to say that protection and exploitation of nature are two sides of the same coin, considering them as a dual process of the interaction between the nature and the society. It is interesting that representatives of economic science tend to see nature protection as a kind of rational exploitation of nature, namely as a broader concept than material

\footnotetext{
${ }^{1}$ Th. W. Hoya. Methods of Market Economy in American and Russian Environmental Law (Хойа, T. Методы рыночной экономики в американском и российском экологическом праве) / Th. W. Hoya // International University, Newsletter (Вестн. междунар. ун-та). Law. Issue No. 5. - Moscow, 2001. - P. 152.
} 
production, since it covers not only product consumption and reproduction of natural resources, but also environmental protection activities in regard to withstanding degradation and pollution of nature to shape the foundation of the future civilization. Such opinion is reasonable to some extent, because, in addition to the use of minerals, water and atmospheric air for the production and operation of transport, even the use of the environment for waste disposal or wastewater disposal purposes should be considered as a type of exploitation of the environment. Indeed, even landfilling requires the permission of the landowner, even though it may involve subsoil or water resources. However, for the nitrogen fertilizers production by means of nitrogen removal from the atmospheric air, no environmental use permit has been established, despite the fact that the author included relevant proposal regarding legal regulation of the use of atmospheric air for industrial needs into the draft Law of Ukraine "On the protection of Atmospheric Air" Instead, the Ministry of Environmental Protection of Ukraine exerted pressure on the relevant committees of the Ukrainian Parliament (Verkhovna Rada of Ukraine), using political party support to remove the referred article from the Law of Ukraine "On the protection of Atmospheric Air" in the late 1990s.

Therefore, nowadays the system of legal norms, united by a common subject, namely legal relations in the field of protection and use of natural resources, includes not only the norms of environmental safety and environmental protection law, but also land, water, forest, subsoil, faunistic, floristic, aeronautical legislation (which are or have already been formed as separate fields of law or fields of legislation, undergoing legal transformation into fields of law). In the light of the above-mentioned problems regarding the combination of global and local approaches to environmental issues and the use of natural resources, there is an increase in the role and capabilities of legal science both in the historical context for the study of national environmental legal traditions and in the context of comparative jurisprudence described by us "the law of united vessels" (as a phenomenon of mutual flow of advanced ideas, rules, principles and concepts between national legal systems, as well as between them and international law), as well as provision of complex systematic approach to the development of environmental law that makes it possible to take into account the most diverse developments. Exactly such approach has laid the foundation for the formation of the subject of this book.

Prof. Vasyl Kostytsky 


\section{ECOLOGICAL SECURITY: LEGAL CONCEPT, ATTRIBUTES, CRITERIA AND POSITION IN THE SYSTEM OF NATIONAL SECURITY}

\section{Balyuk G., Kovalchuk T.}

\section{INTRODUCTION}

The legal basis of ecological security is recognized to be one of the critical prerequisites for maintaining livelihood of society. Ecological law must play an essential role in solving this daunting task with theoretical development of conceptual framework to be clearly understood both by ecological law theorists and practitioners. One of such cardinal concepts in this framework is 'ecological security'.

\section{Legal concept, attributes and criteria of ecological security}

A human being and nature. Our ancestors were sure of some mysticism in their coexistence and worshiped the elements of nature. Nowadays people, armed with scientific knowledge, believe they are the peak of nature and thoughtlessly waste its life force. Greenhouse effect, extinction of many plant and animal species, contaminated water and air have become reality of modern life.

$\mathrm{XX}$ century gave rise to the problems that concern not only single states or regions but humanity as a whole. The relationship between people and nature have become extremely aggravated. Throughout their history people have been using natural resources extensively, constantly mounting pressure on the environment.

The use of resources has dramatically changed the quality of life; however, economic growth aimed at quantitative factors has eventually resulted in large-scale environmental contamination and, in certain cases, has led to irreversible consequences, having changed the features of the Earth.

For a long time many states made economic strength and growth their chief priority, gaining it by any, sometimes dangerous, methods. Rapid industrialization and globalization processes continued until the second half of XX century when countries faced a challenge of limited natural resources, depletion of many of them and, as a result, inability to secure sustainable rates of economic growth in the long term. Ecological deterioration has been gradually turning into a planetary crisis encompassing different aspects of human life. The crisis has been caused by a number of factors: fast depletion of natural resources, environmental degradation, unfavorable demographic 
situation, poverty and starvation in many regions of the world, constant social conflicts, wars with mass destruction weapons, threat of international terrorism, etc.

So, humanity is living through complicated and contradictory times: on the one hand, everyone is interested in industrial and agricultural output growth, as well as in profit and gain. On the other hand, we tend to turn a blind eye to predatory, wasteful use of land, forests, water resources, poaching and nature extinction. But not any economic, technological or scientific accomplishment will make us happy if drinking water in Ukraine becomes unhealthy, if we breathe smog instead of clean air, if we consume food made of genetically modified plants.

However, the ecological situation both on the planetary scale of the Earth and in our country indicates that the industrial growth rates, increased anthropogenic impact on the environment, emergence of areas suffering from ecological disasters have put human life and health under threat. All this required the development of legal norms to grant security of a human in the process of environmental changes which later evolved as the institute of ecological security law and still later as one of the ecological law components - the ecological security law. As far as substantiation of ecological security law is concerned, the statement of V. Andreytsev seems to be relevant: "If one is doomed to Golgotha, it is not about protection but about salvation of the doomed one". Being a source of high insecurity, the environment, due to the activity of the natural elements or human-made catastrophe, turns into ecologically insecure object that requires 'isolation' from an individual and society, from other natural systems and complexes by establishing special legal mode that would limit or prohibit residence of people, social and private production activity, as well as would provide for carrying out measures to eliminate insecurity sources, establishing status of citizens who suffered due to insecurity ${ }^{1}$.

It should be noted that clear definition of the concept of ecological security, specifying its legal status as well as its criteria and threats to it, is not only of theoretical but also of great practical value. However, there is no single generally accepted viewpoint regarding the legal nature of 'ecological security' concept.

Today, there is a big number of approaches to define ecological security. Considering the ways of the concept definition, we should take into account the fact that the interdisciplinary scientific notion 'security' is in its basis.

1 Andreytsev V. Environmental Safety Law: Teaching and science-practical. tool / V.I. Andreytsev. K. : Znannya-Press, 2002. 332 p. 
It is worth mentioning, that security issues attracted attention of scholars since the time of Ancient Greece. According to "social contract theory" (Epicure, Spinoza, Diderot), the essential reason for state formation was accession to "the social contract" in order to overcome "the natural state of the war of all against all", and the main goal of a state is to ensure security of both society and an individual ${ }^{2}$.

During monarch reign this concept involved ensuring security of a monarch, ruling class and monarchy itself. But at the beginning of Renaissance and Enlightment a man (a citizen) - society (a political nation) - a state were considered as the objects of security. At the same time, a state was regarded as the subject of security. The issues of security and survival, the structure of relationship between government, population and state, committed to secure welfare and protection from external threats, were considered in the works of outstanding scholars of Renaissance, N. Machiavelli ("The Prince") and T. Hobbes ("Leviathan") in particular, laying grounds for modern theory of state as well as for political science as a whole. Security was defined as "the means of collective protection" in the war of "all against all" and considered to be the basis of state. In other words, security ensured by state was believed to be the prerequisite for survival and development of an individual as a "human being civilized by the threat of death" ${ }^{3}$.

The role of law and state in providing security of an individual and society was considered in I. Kant "Perpetual Peace" and G. Hegel "Philosophy of History", "Philosophy of Law". The issues of internal and external security were developed in works of Montesquieu, Bentham, Burke, Lipinski, Dontsov and other ${ }^{4}$.

Summarizing philosophical approaches to the term 'security', we can arrive at a conclusion that its definition is always related to the notion of 'state' - that is a category of scientific learning attributed with the capacity of moving matter to manifest itself in different forms with specific features and relationships ${ }^{5}$. Security is considered to be a state of being protected, lack of different kinds of threats.

${ }^{2}$ Skakun O. Theory of State and Law: textbook / O.Skakun: trans. from Rus. Kharkiv: Consum, 2001. $656 \mathrm{p}$.

${ }^{3}$ National Security of Ukraine: History and Present / Ed. O. Goncharenko. K., 1993. 82 p.

4 Yurkevich Pamphil. History of Philosophy of Law. Philosophy of Law / Pamphil Jurkevich // Philosophical Diary. $2^{\text {nd }}$ ed. K. : Editorial in the magazine "Ukrainian World", 2000. 769 p.

${ }^{5}$ Philosophical Encyclopedic Dictionary / [Ed.: S. Averintsev, E. Arab-Ogly, L. Ilyichev et al.]. 2nd ed. M. : Soviet Encyclopedia. 1989. 815 p. 
Similar definition can be found in reference sources where security is viewed as lack of threats to an object from internal or external factors ${ }^{6}$. Depending on the origin of a threat, the nature of its emergence, there is differentiation of threats into ecological, economic, political, military security, etc. Security is assumed to be an indispensable feature of any system, which, in its turn, is reflected in such systemic characteristics as integrity, relative independence and constancy ${ }^{7}$.

It is to be noted that there are two principal approaches to definition of a legal concept of ecological security.

Within the first one ecological security is understood as a certain state. G. Serov in particular, defines ecological security as a condition when the vital interests of an individual, society and state are protected from threats:

a) coming from natural objects whose features have changed due to pollution, littering related to anthropogenic activity (occurrence of accidents, catastrophes, durable business, military and other kinds of activity) or have been changed intentionally by environmental diversion, aggression or natural phenomena and disasters, b) caused by destruction, damage or depletion of natural resources (the threat of non-provision of community and state with natural resources) $)^{8}$.

M. Vedenin gives definition of ecological security as a state of protection of an individual, society, state and environment from adverse natural and technogenic impact that is secured by legal, economic, scientific, technological and other means and ways ${ }^{9}$.

Ecological security is also considered to be a state when all environmental components due to the balance of reciprocal impacts of natural, technological and social systems and the formation of natural and cultural environment are optimal for normal functioning and development of human civilization ${ }^{10}$.

In the field of economics 'ecological security' is defined with regard to its role in economic development of a country. Therefore, there is a viewpoint that this is a certain state understood as adequacy of ecological conditions to

\footnotetext{
${ }^{6}$ Great Interpretative Dictionary of Modern Ukrainian / [ed. By V. Busel.]. K. : Irpin. Perun. 2002. 1440 p.

${ }^{7}$ Lapina M. Ensuring of environmental security by law enforcement agencies: foreign experience: monograph / M.A. Lapina. M. : VNII Ministry of Internal Affairs of Russia, 2001. $115 \mathrm{p}$.

${ }^{8}$ Serov G. Legal regulation of issues of environmental security in industrial and other activities / G. Serov. Moscow: Os-89, 1998. 222 p.

${ }^{9}$ Vedenin N. Environmental Law: Textbook. [for university students ] / Vedenin N.N. M. : Law. 2000. P. 20.

${ }^{10}$ Mahmud A.A. Environmental safety as a subject of international cooperation policy: $\mathrm{PhD}$ reference paper: 23.00.02 / A.A. Mahmoud: Inst. Of State and Law. V.M. Koretskiy NASU. K., 2000. 24 p.
} 
the objectives of preserving health of population and securing sustainable social and economic development ${ }^{11}$.

Proceeding from this definition, we can express ecological security as a monetary value. In case of non- compliance with ecological standards, the environmental quality degrades and there arises the need to somehow compensate its negative impact on people's health as well as on production sector (e.g. agriculture). Compensation measures, in their turn, require appropriate funding. In addition, duration, scale and intensity of ecological insecurity factors may increase the necessary amount. All these make up the cost of ecological security for a state and entrepreneurial entities. For an individual the cost includes spending on healthcare service, on installation of additional air and water purification devices, etc. Considering this, ecological security is held to be an economic value which has its monetary value ${ }^{12}$. The need for development of ecologically safe production, including produce for export, is substantiated and supported by facts of popularity of clean organic products worldwide and in developed countries, in particular, as well as by emergence of certain 'ecological phobia'.

Other sources reveal the content of ecological security relating it to national ecological interest ${ }^{13}$ or the interest in the sphere of ecological security ${ }^{14}$, meaning integrated state interests which determine the policy in the field of ecological security.

The most comprehensive definition of ecological security concept, in our opinion, was offered by V. Andreytsev. He believes that ecological security as a category of law is a component of national and transnational security, that is taken to be such state of development of social and legal relationships when legal norms system as well as other state and social means secure the right of citizens to safe for life and health environment, provide for regulation of activities hazardous for environment, prevent environmental degradation as well as other consequences which may be dangerous for life and health of an individual, society and state and that requires clear constitutionalization in the effective law ${ }^{15}$.

11 Economy, freedom, solidarity. [G. Hofman, V. Demetyev, N.Fedorenko M. : Nauka, 1991. 304 p.

12 Economy, freedom, solidarity. [G. Hofman, V. Demetyev, N. Fedorenko M. : Nauka, 1991. 304 p.

${ }^{13}$ Khlobystov EV Ecological security of transformation economy / E. Khlobystov: RVPS of Ukraine of NAS of Ukraine. K. : Chornobylinterinform Agency. 2004. 336 p.

${ }^{14}$ Kachinsky A., Khmil G. Ecological security of Ukraine: analysis, forecast, evaluation and state policy / A. Kachinsky, G.Khmil. K. : NISD, 1997. 130 p.

15 Andreytsev V. Environmental Safety Law: Teaching and science-practical. tool / V.I. Andreytsev. K. : Znannya-Press, 2002. 332 p. 
The second approach to definition of ecological security is understanding it as a certain activity. Researching issues of ecological security, M. Malyshko considers it as a system of measures aimed at protection of vital interests of an individual from adverse environmental impact. Meanwhile he rightly notes that ecological security is a focal issue of human ecology, since a human being, its interests and eco fund are direct objects of protection ${ }^{16}$. However, this definition does not take into account the impact of technogenic factors and the possibility of such impact coming from modified environment cannot be excluded.

In opinion of S. Bogolyubov, ecological security is the process of ensuring security of vital interests of an individual, society, nature and state from actual and potential threats, caused by anthropogenic and natural impact on the environment.

A great number of approaches to definition of ecological security concept mentioned above brings about legal issues related to determining the field of law the concept belongs to, and this uncertainty, in its turn, does not enable to define the unified concept 'ecological security'. So, we are confronted with a peculiar 'vicious circle'. In our opinion, the first approach, relating the content of ecological security to a certain state, is correct, since ecological security is both a goal and a task for activity of all stakeholders, though the process of ensuring security or activity in this sphere does not still guarantee a result. In addition, law-makers also relate ecological security to a state.

Taking into consideration the approaches mentioned above, we can arrive at a conclusion that ecological security as a category of law should be regarded as security of vital interests of an individual, society, state and environment, which guarantees the right of every individual to healthy and safe environment and provides all necessary conditions for environmental protection, reproduction of natural resources and exercising other rights of citizens as well as interests of the state.

So, the notion 'ecological security' is a hyponym of a broader concept 'security' originating from Latin securitas meaning "condition of being secure" and is considered a component and a prerequisite for national and international security. According to the Law of Ukraine "On National Security of Ukraine" of June 21, 2018, national security means protection of state sovereignty, territorial integrity, democratic constitutional order and other national interests from actual and potential threats ${ }^{17}$.

16 Malyshko MI Environmental Law of Ukraine: Educ. tool. K. : Yuridichna Kniga Publishing, 2001. 389 p.

${ }^{17}$ Law of Ukraine "On National Security of Ukraine" of 21 June 2018 // Verkhovna Rada of Ukraine Bulletin, 2018, No. 31, Art. 241. 
The Law of Ukraine "On Environmental Protection" treats ecological security as "the environmental state that provides prevention of ecological degradation or emergence of insecurity for people's health" (Article50) ${ }^{18}$. It is clear that definition of ecological security is at a number of points different from general definition of national security. The first points out the necessity to prevent ecological hazards, while the second notes not only prevention but also detection and mitigation of actual and potential threats to national interests, including ecological threats.

The State Standard of Ukraine "Security of industrial plants. Terms and definitions" gives the definition different from legislative formula of ecological security provided by the Law of Ukraine "On Environmental Protection". The standard defines security of population, material projects and environment as lack of unacceptable risk related to possibility of causing any damage. In reference addendum to the standard ecological security is inferred from lack of actions, states or processes which directly or indirectly lead to considerable damage to environment, population and material objects ${ }^{19}$.

The definition quoted above formulates the attributes of ecological security relating them primarily to lack of unacceptable risk. The standard actually proceeds from the concept of ecological security, the core of which is the theory of ecological risk ${ }^{20}$ (theory of lack of actual and potential threats).

Naturally, the question arises: what kind of notion that is so frequently used in different fields of law ecological risk is. As a matter of fact, different definitions can be found in different fields. The notion of risk came to ecological law, ecological legislation and practice from mathematics, statistics, probability theory of games, theory of decision making. Recommendations of international organizations (e.g. of the International Commission on Radiological Protection - ICRP) were of considerable importance for understanding, adopting and using this term.

In encyclopedic sources the category of risk is considered as probability of occurrence of undesirable events and consequences ${ }^{21}$. In this context the notion of risk is definitely related to occurrence of unpredictable events and adverse consequences that have subjective meaning for unlimited number of people.

\footnotetext{
${ }^{18}$ Law of Ukraine "On Environmental Protection" of June 25, 1991. The Verkhovna Rada of Ukraine Bulletin, 1991, No.41, Art. 546.

19 State standard of Ukraine. Safety of industrial enterprises. Terms and definitions. DSTU 2156-93. K., 1994.

${ }^{20}$ Environmental risk and national security // Economy. Entrepreneurship. The environment. 1994. № 1. S. 20.

${ }^{21}$ Interpretive Dictionary of Metrology, Measurement Engineering and Quality Management: Basic Terms. M., 1990.
} 
Legal definition of risk can be found in the Law of Ukraine 'On High Risk Objects' of January 18, 2001, according to which risk is probability degree of a certain adverse event that can occur at a certain time or under certain circumstances on the territory of high risk object or beyond $\mathrm{it}^{22}$.

One of the state standards defines risk as probability of adverse consequences from total negative impacts on the environment which cause irreversible ecosystem degradation ${ }^{23}$. Unfortunately, there is no mentioning of an individual, its life and health in this definition.

So, ecological risk is held to be a type of general category of risk and an attribute of ecological insecurity or activity hazardous for ecology. It reflects objective essence of such activity, i.e. probability of insecurity occurrence. The Cabinet of Ministers resolution of 28.08.2013 specifies the list of high ecological risk activities and dangerous objects. It outlines, in particular, the activities which cause such a degree of risk that involves certain legal consequences related to a) subject side of the legal structure, i.e. the duty to foresee and outline preventive measures, and b) object side when specified and permitted activities involve special risk or when particular activity is permitted since it is useful for society and has no alternative at the time. This can be exemplified by the activities related to the use of nuclear energy properties.

Today the regulatory framework of Ukraine specifies the principal types of risky activities and corresponding objects, posing high ecological risk: operations of nuclear power plants, chemical, petrochemical and recycling businesses; biochemical, biotechnological and pharmaceutical production, businesses involved in neutralization, utilization and other kinds of industrial and household waste management, etc. It also provides for the possibility to include here other kinds of activity, other production facilities and processes that may have hazardous impact on environment. Depending on their nature, specifics of physical, chemical and biological composition of used substances, ecologically dangerous activities pose different degrees of ecological risk.

Consequently, ecological risk sources are considered to be environmental activities which, as a rule, are authorized, since in case of unauthorized activity it is due to be stopped without risk assessment, by its presumption. Risk carriers are a number of objects and different substances of natural and artificial origin which under certain natural and social conditions can exhibit properties threatening to human health and life as well as to the world. It

${ }^{22}$ Law of Ukraine "On Objects of High Danger" of January 18, 2001. 73; 2003, No. 30, Art. 247.

23 State standard of Ukraine. Safety of industrial enterprises. Terms and definitions. DSTU 2156-93. K., 1994. 
should also be noted that certain natural phenomena may be sources of danger for a man, society and environment (floods, hurricanes, volcanoes, etc.).

Taking into account that ecologically hazardous activities, objects, substances and their combinations pose high ecological risk, their operations and usage are subject to special regulation, to legal regulation in particular. In other words, legal measures of ecological risk management prove to be necessary. These include the ways of influencing the entities carrying out ecologically dangerous activities which implies application of law norms and realization of legal potential by means of a) assessment of planned activity impact on the environment; b) procedure for making and coordinating ecologically meaningful decisions; c) licensing the activities related to use of sources posing risk to environment, life and health of people; d) submitting security declaration of increased risk object; e) risk insurance; f) certification; g) application of legal liability, etc.

In this respect, legal relationships in the field of ensuring ecological security are recognized as absolute, since citizens possess the absolute right to ecological security that corresponds to the duty of state, legal and physical entities to ensure execution of a number of mandatory requirements concerning ecological security. In this way, for the latter the right to ecological risk is transformed into obligation to take actions aimed at preventing occurrence of ecological insecurity (as manifestation of ecological risk) or eliminating consequences of such insecurity by means of risk aversion or mitigation.

Therefore, a set of conditions and legally fixed actions regarding implementing the procedure of licensing the ecologically insecure types of activities and issuing corresponding permits comprise a certain legal structure as the ground for legal relationship in the field of ecological security. Under certain circumstances, the legal structure can be supplemented by additional actions (legal facts), which prove to be important for emergence of legal relationships in the field of ecological security.

At the same time, there may be other grounds for legal relationship in the field of ecological security, especially when it comes to the universal human right of citizens to natural security. The right is based on risk related to various natural phenomena. The basis for emergence of this set of legal relationship is a number of legal norms that recognize ecological security and maintaining ecological balance on the territory of Ukraine a duty of the state (Constitution of Ukraine, Article 16).

The subjects of legal relations in the field of ecological security are the citizens of Ukraine, natural and legal persons, the state.

The objects of legal relations, mentioned above, are life and health of people, safe natural environment and its elements (natural conditions). 
Therefore, analysis of the effective legislation, professional legal and reference literature enables us to identify significant legal attributes of the concept 'ecological security'. The first one is that ecological security is the subject matter of ecological law, a component of national and transnational security. The second one manifests itself in available system of state-legal and other social means to prevent emergence of various threats through regulation of activities posing ecological risk. The third one refers to the focus of ecological security system in the area of environmentally risky types of activity or natural disasters, capable to bring the state of environment to the level that is dangerous for health and life of people as well as for society and state. The fourth attribute of ecological security is essentially associated with prevention of environmentally risky activities, conditions and processes, that is, with preventive measures.

\section{Ecological security in the system of national security of Ukraine}

Studies of the position and role of ecological security in the system of national security of the state have certain history. Research began at the end of $\mathrm{XX}$ century when awareness of state independence required methodological support to formation of national security policy, study of national security fundamentals as a systemic multicomponent phenomenon and one of the basic principles of state formation. Therefore, consideration of the position of ecological security in current situation of formation of national strategy and balanced policy of sustainable economic, ecological and social development is believed to be an urgent scientific and practical task.

The importance of investigating the place of ecological security in the national security system is related to necessity of analysis, prevention and forecasting of natural and man-made emergencies characterized by constant increase in material costs and social losses. Today, the nature of emergencies has begun to change dramatically, hazards and threats are more interconnected, their research is increasingly becoming interdisciplinary plane. The risk of natural disasters is increasing due to anthropogenic activity, which is the underlying cause for many natural disasters that have occurred in Ukraine recently. These include catastrophic floods in Transcarpathia, uncontrolled deforestation, landslide in mining and high urbanization sites, the phenomenon of man-made seismicity in many regions of Ukraine, etc.

"The Main Principles (Strategy) of State Ecological policy of Ukraine for the Period up to 2030", approved by the Law of Ukraine of February 28, $2019^{24}$, outlined the main problems for the state of ecological security of Ukraine.

${ }^{24}$ Law of Ukraine "The Main Principles (Strategy) of State Ecological policy of Ukraine for the Period up to 2030" of February 28, 2019. Verkhovna Rada of Ukraine Bulletin, 2019, No. 16, Art. 70 . 
Deterioration of atmospheric air quality. One of the reasons that cause poor air quality in the settlements and concentration of greenhouse gases in the atmosphere is non-compliance of economic entities with ecological legislation norms and low rates of implementation of advanced technologies. In order to improve the quality of atmospheric air and strengthen response to climate change and to achieve the aim of sustainable low carbon development in all sectors of economy, Ukraine must enforce ratified international documents on counteraction to climatic change and ambient air improvement.

Climate change. At the beginning of XXI century climate change was recognized by the world community as one of major problems of the global development with potentially serious threats to global economy and international security due to direct and indirect risks related to energy security, provision of food and drinking water, ecosystem sustainability, risks to human health and life. According to the Paris Agreement, Ukraine, as a party to the agreement, is obliged to make its nationally defined contribution to achieve the goal of sustainable low carbon development in all sectors of economy and to increase its capacity to adapt to the unfavorable climate change effects, in particular by decreasing total greenhouse gases emission.

Problems in the sphere of water protection. Ukraine is one of the European countries having the least water supply. Due to toxic, microbiologic and biogenic pollution, the ecological state of river basins, as well as of coastal waters and territorial waters of the Black Sea and the Azov Sea is deteriorating. The current water monitoring system in Ukraine is inefficient and outdated, does not meet current European standards. The system of public administration in water protection sphere requires reformation and transition to actual, not formal, integrated management of water resources by the basin principle.

Problems in the field of protection of land and soils. The current use of land resources of Ukraine does not meet the requirements of rational use of nature. The state of land resources of Ukraine is close to critical.

The reasons for such situation are complex and have historical background. Especially noteworthy is the violation of ecologically balanced ratio between land categories, the reduction of unique steppe areas, excessive plowing of territories and the violation of processes of natural soil formation, the use of imperfect technologies in agriculture, industry, power sector, transport and other sectors of the economy, aiming at gaining short and medium-term economic benefits while ignoring the environment preservation component.

Problems in the field of forest protection. The main causes of problems in the forest area are the imperfection of the forest management and forestry development, the lack of legal and economic mechanisms as well as the 
incentives for introduction of conservation technologies, the imperfection of the tax base and the unclear definition of the legal regime for management of lands sheltered with forest belts.

Issues in the field of use and protection of subsoil. There are systemic problems in the area of subsoil use in Ukraine, which pose a real threat to the economic security of the state. In Ukraine, which is 0.4 percent of the planet's land surface, up to five percent of all mineral resources of the globe have been discovered. The country possesses more than 20 thousand deposits and ores of 95 types of minerals, of which about 8 thousand are of industrial importance and are accounted for by the State Balance of Minerals. The total number of developed fields is about three thousand. At the same time, inefficient public administration in this area, lack of investment, use of obsolete equipment by mining companies, depreciated to 70 percent, and the outflow of qualified specialists have led to poor quality of industry performance.

The transition to resource-saving technologies, the full implementation of environmental impact assessment, the obligatory reclamation and inevitable responsibility for violations of the environmental legislation should be the main directions of balanced use of Ukrainian subsoil.

Emergency risk. On the territory of Ukraine there is a high risk of natural and man-made emergencies, the main reasons being: obsolescence of fixed assets, in particular those designed for environmental protection; large volume of transportation, storage and use of hazardous substances, emergency condition of a large part of public utility networks, insufficient investments into introduction of environmentally friendly, resource- and energy-saving technologies, especially in metallurgical, chemical, petrochemical industries and power sector; significant changes in the state of the geological environment due to the closure of unprofitable mining enterprises; the hydrogeological regime of water bodies; the reluctance of economic entities to take measures to prevent accidents and catastrophes at high risk sites and potentially dangerous objects, etc.

On the territory of the exclusion zone and the zone of unconditional (compulsory) resettlement there are objects of the State specialized enterprise "Chornobyl NPP", which require their decommissioning and putting into ecologically safe state, and objects of the system of radiation-ecological control and radiation monitoring of the environment condition and the provision of radiation safety.

Ecological problems of Donbass. Hostilities, destruction of infrastructure and of environmentally hazardous enterprises on the temporarily occupied territory of Ukraine have upset the ecological balance, which has led to dangerous changes in the environment, caused harm to health and violated the life safety for five million people in the area of about 30 thousand square kilometers. 
The main threats are: flooding of mines and the possibility of toxic mine water coming to the surface, infiltration into groundwater; threat of its running into the river Seversky Donets and the Sea of Azov; termination of operation of treatment facilities and damage to toxic and radioactive waste storage facilities; damage to the territories of the nature reserve fund; atmospheric air and soil contamination by chemical products due to ammunition explosions; the destruction of landscape and vegetation in connection with the use of military equipment and the construction of defense structures; the destruction of large areas of forests as a result of warfare and uncontrolled deforestation.

Environmental monitoring of the Donetsk and Luhansk regions, where government bodies temporarily do not exercise their authority, with the possible engagement of international environmental experts to assess the ecological situation, is becoming increasingly urgent.

Problems with waste management. Unlike European countries, Ukraine has a very low level of solid waste recycling and disposal and a high landfill level. Much of the landfill is overloaded and does not meet environmental and sanitary standards.

A significant threat to the environment and human health is the waste generated in the process of medical care, processing of raw materials of animal origin, pharmacological and cosmetic industries containing dangerous pathogenic and conditionally pathogenic microorganisms, as well as electrical and electronic equipment wastes.

The underlying reason for this situation is the imperfect legal framework, the lack of an efficient accounting and reporting system, and a monitoring system in the field of waste management.

Solving this problem is key to energy and resource independence of the state, saving natural material and energy resources, and is also the task of state environmental policy.

Problems in the field of biosafety. Priorities of the state policy in the field of biological security and biological protection are implementation of systematic measures for creation and effective functioning of the national system of biological security and biological protection, counteraction to acts of bioterrorism, protection of the population against the uncontrolled and unlawful spread of genetically modified organisms, preservation of safe for human health state of the environment, creating an early detection and fast response system to prevent the spread of pathogens of especially dangerous diseases and those of international importance, as well as improving the logistics of laboratories, establishments and institutions carrying out diagnostics of infectious diseases, monitoring of laboratories which work with pathogens of especially dangerous infectious diseases, determining their 
impact on the environment, in particular on biodiversity, with account of the risks to human health; creation of a system of rapid response to the manifestations of bioterrorism.

Threats to biological and landscape diversity. Occupying less than 6 percent of Europe's area, Ukraine owns about 35 percent of its biodiversity. The biosphere of Ukraine has more than 70 thousand species of flora and fauna, in particular flora - more than 27 thousand species, fauna more than 45 thousand species. In recent years there has been an increase in the number of plant and animal species included in the Red Data Book of Ukraine.

The main threat to biodiversity comes from human activities and the destruction of the natural habitat of flora and fauna. There is a catastrophic decrease in the area of wetlands, steppe ecosystems, natural forests, which is caused by land plowing, deforestation with a further change of land use purpose, drainage or hydration of territories, industrial, residential and holiday home construction, etc. The spread of non-native species in natural ecosystems causes considerable imbalance in biocenoses.

In order to curb biodiversity loss, Ukraine should take into account the recommendations of international documents on the revision and updating of legislation and standard acts on biological diversity.

Ukraine, like any other sovereign state, is building its own national security system. Recently, for Ukraine, this problem has become urgent due to both fundamental changes in the basic values of internal development and changes in the external environment. In particular, this is about:

1) transformation of socio-economic model of development from administrative-command to market and democratic political system;

2) positive and negative effects of the proposed reforms;

3) dismantling international and European security systems;

4) aggressive policy of the Russian Federation against Ukraine (annexation of the Crimea, waging a "hybrid war" in the east of Ukraine, diversions throughout Ukraine, evil anti-Ukrainian information propaganda among the population of Russia, Ukraine, and the entire world community in order to achieve geopolitical strategic revenge of "the Russian world";

5) increasing threats of a global nature (depletion of natural resources, pollution of the environment, etc.).

The above forces constantly identify and timely assess the real and potential threats to Ukraine's security in order to identify specific ways and means of preventing them. Ukraine's national security is directly linked to the determination of its national interests, which reflect the higher interests of society and the citizen. 


\section{CONCLUSIONS}

In terms of a global approach to security, any aspect that threatens the survival of the planet and its nature must be considered a security threat. Death from a nuclear disaster and death from air shortage is still death. The pace of the global changes, mentioned above, is much higher than it was previously predicted by scientists. If these processes remain uncontrolled, they will become irreversible.

Environmental problems are problems of completely new dimensions. Even with unlimited resources, it is impossible to recover the ozone layer or to "seal the ozone hole". Global warming cannot be stopped if its causes are not eliminated. The disparities in economic development affect the ability to protect against environmental threats, and environmental degradation influences economic development, weakening its potential. According to UN experts, environmental losses due to pollution exceed the cost of measures aimed at fighting it. In developing countries they are much larger than in developed states. Each year, from 0.5 to $2.5 \%$ of GNP is lost due to pollution, and the cost of measures that would radically reduce pollution in industrial countries accounts for 1-2\% of GNP.

Modern changes in international relations are exacerbated by factors that affect the security of both the individual state and the system of states. Firstly, environmental threats do not have the nature of targeted actions. They are only unintended consequences of environmental disasters or development processes. Secondly, environmental threats cannot be subject to international standards of border or state integrity. Environmental threats can cause tensions in international relations and bring about new types of conflict that cannot be settled even through joint military action. Conversely, their settlement becomes an element of interaction, bringing states and peoples closer.

Environmental threats that can disrupt international stability include massive migration of people from areas of natural and man-made disasters (such as droughts in East Africa or the Chornobyl disaster), and the enormous environmental damage caused by industrial emissions, forest degradation, extinction of biodiversity and finally climate change. Thus, the concept of security has significantly expanded. Security is becoming a comprehensive category that covers most of the challenges of protecting the population from all types of threats.

\section{SUMMARY}

Environmental threats are not clearly identifiable as cause - effect relationship, but they are quite closely interrelated and linked to other social, political and economic factors that also affect the security situation. 
Intensified fight for ownership and use of clean air, water, arable land, fisheries and food resources, once considered free, is now a real threat to regional security.

The consideration of the time factor is important in addressing environmental security, as these threats remain vitally important in the long run. Sixth, the ecological aspect of security covers the actual existing threats, as a result, the level of security of the state, region and the world as a whole becomes dependent on them. The better humanity is aware of the complex relationship between environmental conditions in different corners of the globe, the more serious it becomes in understanding the regional and even global effects of particular environmental changes. Solving environmental problems on a global scale requires concerted action of governmental and non-governmental organizations, cooperation between states and regions, and the development of long-term environmental policies. Therefore, environmental security is increasingly becoming an integral component of national and global security.

\section{REFERENCES}

1. Andreytsev V. Environmental Safety Law: Teaching and sciencepractical. tool / V.I. Andreytsev K. : Znannya-Press, 2002. 332 p.

2. Environmental risk and national security // Economy. Entrepreneurship. The environment. 1994. № 1. S. 20.

3. Economy, freedom, solidarity. [G. Hofman, V. Demetyev, N. Fedorenko. M. : Nauka, 1991. 304 p.

4. Great Interpretative Dictionary of Modern Ukrainian / ed. by V. Busel. K. : Irpin. Perun. 2002. 1440 p.

5. Interpretive Dictionary of Metrology, Measurement Engineering and Quality Management: Basic Terms. M., 1990.

6. Kachinsky A., Khmil G. Ecological security of Ukraine: analysis, forecast, evaluation and state policy / A. Kachinsky, G. Khmil. K. : NISD, 1997. $130 \mathrm{p}$.

7. Khlobystov E.V. Ecological security of transformation economy / E. Khlobystov: RVPS of Ukraine of NAS of Ukraine. - K. : Chornobylinterinform Agency. 2004. 336 p.

8. Lapina M. Ensuring of environmental security by law enforcement agencies: foreign experience: monograph / M.A. Lapina. - M. : VNII Ministry of Internal Affairs of Russia, 2001. 115 p.

9. Law of Ukraine "On National Security of Ukraine" of 21 June 2018 // Verkhovna Rada of Ukraine Bulletin, 2018, No. 31, Art. 241.

10. Law of Ukraine "On Objects of High Danger" of January 18, 2001. 73; 2003, No. 30, Art. 247. 
11. Law of Ukraine "On Environmental Protection" of June 25, 1991. The Verkhovna Rada of Ukraine Bulletin, 1991, No. 41, Art. 546.

12. Law of Ukraine "The Main Principles (Strategy) of State Ecological policy of Ukraine for the Period up to 2030" of February 28, 2019. Verkhovna Rada of Ukraine Bulletin, 2019, No. 16, Art.70.

13. Mahmud A.A. Environmental safety as a subject of international cooperation policy: $\mathrm{PhD}$ reference paper: 23.00 .02 / A.A. Mahmoud: Inst. of State and Law. V.M. Koretskiy NASU. K., 2000. 24 p.

14. Malyshko MI Environmental Law of Ukraine: Educ. tool. K. : Yuridichna Kniga Publishing, 2001. 389 p.

15. National Security of Ukraine: History and Present / Ed. O. Goncharenko. K., 1993. 82 p.

16. Serov G. Legal regulation of issues of environmental security in industrial and other activities / G. Serov. Moscow: Os-89, 1998. 222 p.

17. Skakun O. Theory of State and Law: textbook / O. Skakun: trans. from Rus. Kharkiv: Consum, 2001.656 p.

18. State standard of Ukraine. Safety of industrial enterprises. Terms and definitions. DSTU 2156-93. K., 1994.

19. Philosophical Encyclopedic Dictionary / [Ed.: S. Averintsev, E. ArabOgly, L. Ilyichev et al.]. 2nd ed. M. : Soviet Encyclopedia. 1989. 815 p.

20. Vedenin N. Environmental Law: Textbook. [for university students ] / Vedenin N.N. M. : Law. 2000. 336 p. 20.

21. Yurkevich Pamphil. History of Philosophy of Law. Philosophy of Law / Pamphil Jurkevich // Philosophical Diary. $2^{\text {nd }}$ ed. K : Editorial in the magazine "Ukrainian World", 2000. 769 p.

Information about the authors: Balyuk G.,

$\mathrm{PhD}$ (Law), Corresponding Member of the National Academy of Legal Sciences of Ukraine, Professor at the Ecological Department, Kyiv National T. Shevchenko University 60, Volodymyrska str., Kyiv, 01033, Ukraine

ORCID: 0000-0001-5855-0142

Kovalchuk T., $\mathrm{PhD}$ (Law), Associate Professor, Head of Ecological Law Department, Kyiv National T. Shevchenko University 60, Volodymyrska str., Kyiv, 01033, Ukraine

ORCID: 0000-0003-0157-2767 


\section{THE CONCEPT OF ECOLOGICAL LAW AND ITS PLACE IN LEGAL SYSTEM}

\section{Kostytsky V.}

\section{INTRODUCTION}

Peculiarities of modern globalized world stipulate the necessity in reframing our ideas about law and state and their role and place in development of civil society. The development of legal system leads to severance of new legal branches and institutes. Therefore, we will logically begin our research of ecological law place and role in legal system from analysis of modern understanding law and legal system, law structure peculiarities and other theoretic and methodological problems. Finding out the question of the essence of a particular branch of law and its place in the system of law requires the study of the socio-legal bases of its origin, history of origin, principles and possible ways of development.

\section{Sociological and legal basis for the emergence of environmental law}

State legal system determines not only the form of government, political (legal) regime but also characterizes the features of its modern development, as the modern state cannot be isolated from the global world. Legal system is a system of legal norms, or legal norms and legal relations, or construction of law as a normative formation and correlation of law-making and enforcement ${ }^{1}$.

In the common social understanding law means certain possibilities of social life subjects determined by the level of social development ${ }^{2}$. Thus, law turns from limitation of law into phenomenon where system of person's limitations and his/her duties corresponds with state's duties and person's possibilities.

1 Костицький В. В. Екологія перехідного періоду: право, держава, економіка (економіко-правовий механізм охорони навколишнього природного середовища в Україні) / В. В. Костицький ; Інститут законодавчих передбачень і правової експертизи. К. : УСП МСБ "Еusmeu”, 2003. - 772 с. - (Серія "Екологічна бібліотечка" ; № 5) (Бібліотечка журналу "Малий та середній бізнес"). - С. 189-203. Kostytsky V.V. Ecology of Transition: Law, State, Economy (Economic and Legal Mechanism of Environmental Protection in Ukraine) / VV Kostytskyi; Institute for Legislative Predictions and Legal Expertise. - K.: USSB SME Eusmeu, 2003. - 772 p. - (Series "Ecological Library"; № 5) (Library of the magazine "Small and Medium Business"). - P. 189-203.

${ }^{2}$ Рабінович П.М. Права людини та їх юридичне забезпечення (основи загальної теорії права і держави). - К., 1992. - С. 7. Rabinovich PM Human rights and their legal support (foundations of the general theory of law and state). - K., 1992. - P. 7. 
During the last decades in Ukraine the law was traditionally examined as a mirror of public relations reflected only attained level of development and deprived of creative force as a secondary (built-on) element of reality, an addition to economic relations which serves the tools of economy. Peculiarity of the previous approach to understanding law was determined by the Soviet subjective normativizm ${ }^{3}$, i.e. denial of the private in law, absolutization of public law, stipulated by ideological vision of law set by the state.

This, in our opinion, generated legal nihilizm, underestimation of law, ignoring it in enormous scales of socio-economic development of a giant state.

"First of all, law is direct presence of existence...", wrote G. Hegel in his work "Philosophy of Law", in other words the phenomenon and essence without which it is difficult to imagine the modern society. A fashion on G. Hegel did not pass but his definition of law as a necessary element of existence was understood somewhat simplified.

Law is a social phenomenon ${ }^{5}$, an achievement of spiritual culture and art that is why law cannot be deprived of creative basis with the help of which new socio-economic relations develop. Ukrainian experience, the Constitution of Ukraine (1996), the project of which was created with the author's input as a model for development of the state, forming the legal system, civil society and a new free man, is the best argument in favour of such a statement.

Law as an organized matter of high spirit shows us such aspects which we did not notice before. Let us recall that an ancient saying interprets law as an art of good and justice. Obviously, the Constitution of Ukraine developing this position in the Article 3 has ascertained that a person, their freedom determine

${ }^{3}$ Костицький В. Приватне право і підприємництво в Україні. Вступ до збірника наукових праць "Приватне право і підприємництво”. - К., 1999. - С. 5-11. Костицький В.В. Методологічні проблеми кодифікації екологічного законодавства / В. Костицький // Малий і середній бізнес (Право, Держава, Економіка). - 2011. - № 3-4. - С. 3-6; Костицький В.В. Міжнародно-правовий етичний імператив як основа теоретико-методологічного забезпечення розвитку екологічного права / В. Костицький // Право України. - 2011. № 2. - C. 20-33. Kostytsky V. Private Law and Entrepreneurship in Ukraine. Introduction to the collection of scientific works "Private Law and Entrepreneurship". - K., 1999. - P. 5-11; Kostytsky V.V. Methodological problems of codification of environmental legislation / V. Kostitsky // Small and medium-sized business (Law, State, Economics). - 2011. - № 3-4. P. 3-6; Kostytsky V.V., International legal ethical imperative as the basis of theoretical and methodological support for the development of environmental law / V. Kostytskyi // Law of Ukraine. - 2011. - № 2. - P. 20-33.

${ }^{4}$ Гегель Г.В.Ф. Философия права. - М.: “Мысль”, 1990. - С. 99. Hegel GVF Philosophy of Law. - M. : "Thought", 1990. - P. 99.

${ }^{5}$ Алексеев С.С. Право. Азбука. Теория. Философия. Опыт комплексного исследования. - М.: Статут, 1999. Alekseev S.S. Right. Alphabet. Theory. Philosophy. Experience in complex research. - M. : Charter, 1999. 
the substance and directions of country's activity, turning law from the gifted possibility into the system of conventional rules of equal subjects - the person and the state.

Freedom and necessity are two real criteria, two real keys to understanding law as an integral phenomenon which combines public and private life of the society. Freedom per se is alive when like a bird it can have two wings, one of which is private life of a person, based on the right to one's own identity and private property, and the second is the right to participating in public life, obviously, foremost - the right to vote. And then the necessity is understood as a duty of an individual to take into account public and private interests while realizing one's own interests.

Contrary to legal system as a multitude of all legal phenomena the legal system includes fields of law and institutes of law. There arises a logical question whether it is possible to distinguish branches in the legal system which belongs to private law, and to designate fields of law which are public law. On the level of division of law into branches it is yet possible to talk about it: civil law undoubtedly makes the basis of private law. Natural law, as Ulpian said, also belongs to private law. There are rights and freedoms of a person in natural law which are inalienably proper to it as a biosocial creature and they cannot be given by the state, and only owing to their acknowledgement by the state must be recorded in the constitution as a public agreement of citizens inter se, the civil society and the state. Here the level of publicity of natural law corresponds to the level of publicity of civil law.

Therefore, constitutional law, administrative law, criminal law are branches of public law. However, while considering law as a system which includes structural units, there appears a certain convention in the division of law into public and private. Even in civil law as a field of private law there are public and legal norms, in particular, those which are concerned with legal regulation of intellectual property. And in such fields of public law as constitutional law and land law we can find norms which regulate relations of land leasing. Here the subjects of tenancy contracts are: local self-government bodies and state executive authority, physical or legal entities. The conclusion of tenancy contract happens after the procedure of taking a corresponding decision by the local self-government body or state executive authority, and that is the matter of public law. A decision-making procedure about the conclusion of tenancy contract by a legal entity is a matter of private law.

One of displays of integrity of law apart from its division into public and private and their unity is formation of a complex field of law - "ecological law" that combines in itself forms of public and private law, includes both norms of ecological law and norms of other fields of law. 
Let us try to single out features of this statement:

1. Person's innate right to the environment suitable for life and safe for health and living lies in the basis of ecological law. This right correlates with the corresponding duty of the state which is envisaged presently in the Article 16 of the Constitution of Ukraine: the state is incumbent on providing ecological safety and maintenance of ecological balance on the territory of Ukraine, overcoming consequences of the Chornobyl disaster - the disaster of the planetary scale, genetic conservation of Ukrainian people. This norm of public law found its development in the "Basic Bill of Private Law" - the Civil Code of Ukraine which came into effect in January $1^{\text {st }}, 2004$. In the Article 293 of the Civil Code of Ukraine entitled right to the environment safe for life and health, in particular, is marked: "A physical entity has a right to the environment safe for life and health, right to reliable information on environmental conditions, on the quality of food and everyday life objects, and also a right to its collection and distribution".

2. The activity of physical and legal entities which results in damaging, spoiling and pollution of environment is illegal. Everybody has a right to demand stopping this activity. The activity of a physical and legal entity which harms the environment can be stopped through a court's decision.

3. A physical entity has a right to safe consumer products (food and everyday life objects).

4. A physical entity has a right to proper, safe, healthy conditions of work, living, studying etc. Article 293 of the Civil Code of Ukraine corresponds not only to the Article 16 but also Article 50 of the Constitution of Ukraine which also establishes the right of a person to ecological safety but is narrower in its content.

We can mention once again that a combination of norms of public and private law as demonstration of unity of law and its division into branches but, foremost, of its integrity, can be especially vividly seen in ecological law. Integrity of law is the law of its existence. In our opinion, economic and legal mechanism of environmental protection is one of displays of the integrity of law ${ }^{6}$. The task and optimal result of realization of economic and legal

6 Костицький В. В. Екологія перехідного періоду: право, держава, економіка (економіко-правовий механізм охорони навколишнього природного середовища в Україні) / В. В. Костицький ; Інститут законодавчих передбачень і правової експертизи. К.: УСП МСБ "Eusmeu”, 2003. - 772 с. - (Серія “Екологічна бібліотечка" ; № 5) (Бібліотечка журналу "Малий та середній бізнес"). - C. 189-203. Kostytsky V.V. Ecology of Transition: Law, State, Economy (Economic and Legal Mechanism of Environmental Protection in Ukraine) / VV Kostytskyi; Institute for Legislative Predictions and Legal Expertise. - K.: USSB SME Eusmeu, 2003. - 772 p. - (Series "Ecological Library"; № 5) (Library of the magazine "Small and Medium Business"). - P. 189-203. 
mechanism of protection of natural environment lies in achieving harmonious relations in the "society and nature" system which, for example, is possible to express through the concept of ecological legal order and ecological safety. Professor V. Petrov, in particular, defined ecological legal order as a "system of legal norms and legal relations which determine the mode of rational exploitation of natural resources, environmental protection and ecological safety of the society"7.

In any case the result of legal regulation of ecological relations must convey a certain state of public relations in the sphere of cooperation of society and nature, and in this case the quality of environment is favourable for a person and separate natural components, and the quality and the amount of natural resources cater for the economy of present and future generations of people ${ }^{8}$.

Such efficiency of public relations is possible only under conditions of ecological stability which means the ability of an ecosystem to resist abiotic and biotic factors of the environment, including anthropogenic influences ${ }^{9}$.

Law is practically the only, both effective and resultative, universal instrument of solution to these problems. Because of the combination of principles, functions and tasks, legal norms and rules envisaged in the acts of legislation, the institute of ecological law is called to pawn fundamental principles of forming parameters of behavioural characteristics of subjects of ecological relations through:

- formation of new ecological and legal worldview;

- creation of the effective system of environmental education;

- formation of modern ecological legislation;

- creation of an effective control system in the sphere of exploitation of natural resources and environmental protection;

- development of effective ecological policy and its successive realization;

7 Петров В.В. Закон Российской Федерации об ответственности за экологические преступления (Проект) // Вестник Московского ун-та. - Сер.11. - Право. - 1993. - № 4. C. 54. Поняттю екологічного правопорядку присвячена монографія: Petrov V.V. Law of the Russian Federation on responsibility for environmental crimes (Project) // Bulletin of the Moscow Univ. - Aug.11. - Right. - 1993. - № 4. - P. 54. The concept of environmental law is devoted to the monograph:

${ }^{8}$ Екологічна Конституція Землі. Методологічні засади / [В.В. Костицький та ін. за ред. акад. НАН України, д-ра екон. наук, проф. Ю.Ю. Туниці]. - Львів : РВВ НЛТУ України, 2011. - C. 370-381. Ecological Constitution of the Earth. Methodological basis / [V.V. Kostytsky et al. in a row. Acad. NAS of Ukraine, Doctor of Economics. of sciences, prof. Tunisia]. - Lviv: RVV NLTU of Ukraine, 2011. - P. 370-381.

${ }^{9}$ Протасов В.Ф., Молчанов А.В. Словарь экологических терминов и понятий. - М., 1997. - C. 101. Protasov V.F., Molchanov A.V. Dictionary of environmental terms and concepts. - M., 1997. - P. 101. 
- formulation of legal principles of people's participation in controlling and monitoring in the sphere of exploitation of natural resources and environmental protection.

Optimization of behavioural characteristics of participants of ecological relations on the basis of providing ecological vector in the system of their internal motivations are directed at balancing forms of cooperation of the society and nature. In scientific literature one distinguishes the following forms of cooperation of society and nature:

- economic form - nature consumption, its use for one's own needs;

- biological form - satisfaction of person's physical, biological and other physiological needs on principles of existence in the environment;

- ecological form - protection, environment recreation;

- spiritual form - cultural and aesthetic perception of nature.

The aim of balancing consists in creation of such a model of exploitation of natural resources which would provide the normal process of evolution of the society on principles of steady development. Proper creation of legal principles of realization of the given aim is a key problem for the institute of ecological law that gives ground for considering it from positions of a universal instrument of problem-solving concerning cooperation of the society and nature.

The law of every state as a system which includes such structural units as branches of law is in permanent dynamics. Besides, traditional fields of law such as constitutional, civil, criminal, administrative, financial, labour, civil procedure, procedural criminal law etc., other fields of law are forming and becoming firmly established. Today distinction of ecological law as a branch of law is universally accepted; people continue to discuss further development of economic law as an independent field.

The branch of law unites a relatively independent set of legal norms which regulate certain spheres of public relations. Large branches of law can unite both institutes of law and large groupings - sub-branches of law, i.e. complexes of legal norms which regulate public relations of one kind (banking, budget law included in the branch of financial law). The institute of law is a set of interconnected norms which are isolated inside one or a few branches of law that regulate a small group of public relations of one kind or sides of public relations ${ }^{10}$. Institutes of law in this context may refer to branches or sub-branches.

\footnotetext{
${ }^{10}$ Костицький В.В. Розвиток системи права: проблеми формування нових галузей / В. Костицький // Малий і середній бізнес. - 2008. - № 3-4. - С. 3-14. До питання про розвиток системи права та критерії його поділу на галузі (на прикладі екологічного й повітряного права). - Про українське право: Часопис кафедри теорії та історії держави і права Київ. нац. ун-ту імені Тараса Шевченка / За ред. проф. І. Безклубого. - К.: Грамота,
} 
And, finally, the smallest structural constituent in the legal system is a legal norm, i.e. a certain rule of behaviour, set or sanctioned and provided by the state. The legal norm can be compared to a molecule of the substance. A molecule is the smallest constituent of the substance which carries properties of this substance. A molecule of water is water, and two atoms of hydrogen or an atom of oxygen have different properties in comparison to water. The legal norm is the smallest part of law which has properties and specificity of law. Therefore, equalling a legal norm to a simple rule of behaviour somewhat simplifies the nature of law.

Such peculiarities of law can be most vividly seen in ecological law which includes legal norms directed at environmental protection.

Thus, ecological law is a complex branch of law that regulates legal relations in the sphere of environmental protection, rational use of natural resources and providing ecological safety, i.e. relations related to protection and use of environment on the whole and natural resources of environment with the aim of providing permanent balanced development in interests of present and future generations of people.

In Ukraine the main characteristics of development of ecological law consists in expansion of its action, itemization of many legal requirements. A short process of its development in independent Ukraine underlines the fact that expansion of the sphere of ecological law is an objective process. The tendency of expansion of the sphere of ecological law in Ukraine is far from being exhausted even today. In particular, it is confirmed by the fact that the problem of substantial updating and perfection of ecological law acquires considerable importance. The point is that the intensity of formation of this branch of law has resulted in adoption of many hasty and imperfect legal norms which were often corrected in recent years. Weak financial and economic validity of many statements of ecological law has revealed itself. All this has required earlier and requires now permanent adjustment of a considerable number of existing normative materials, it often generates unsystematic and frequent changes in the mechanism of legal regulation of ecological relations, puts forward the need of codification of ecological law and adoption of the Ecological Code of Ukraine.

2009. - Чис. IV. - С. 128-143 (384 с.). Kostytsky V.V. Development of the Law System: Problems of Forming New Industries / V. Kostytsky // Small and Medium Business. - 2008. № 3-4. - P. 3-14; The question of the development of the system of law and the criteria for its division into industry (for example, environmental and air law). - About Ukrainian Law: Journal of the Department of Theory and History of State and Law, Kyiv. nat. Univ. of Taras Shevchenko / Ed. prof. I. Blessed. - K. : Certificate, 2009. - Numbers. IV. - Pp. 128-143 (384 pp.). 


\section{History of the emergence of Environmental Law in Ukraine}

By examining and analyzing peculiarities of legal support of protection and rational use of the environment and its natural resources in Ukraine we turn to the features of generation and development of ecological law system. It is a separate complex branch of law within limits of the national legal system and it develops with its own specificity. Let us consider the features of development of the legal mechanism of environmental protection in modern Ukraine, not claiming that our analysis will be full and exhaustible.

First of all, we should mention that ecological law as a branch of law of independent Ukraine has developed earlier and develops now on the basis of the science of ecological law, foremost, theoretical works of such Ukrainian scholars as: V. Andreytsev, H. Balyuk, A. Bobkova, A. Hetman, S. Kravchenko, N. Malysheva, V. Muntyan, Z. Pavlovych, O. Pohribnyy, B. Rozovskyy, V. Popov, V. Semchuk, Yu. Shemshuchenko, M. Shulha, Z. Yanchuk, V. Yanchuk, and also scholarly-theoretical ideas of the best representatives of the post-soviet school of ecological law - O. Kolbasov, V. Petrov (Moskow), M. Storozhev (Belarus, Minsk), S. Baysalov (Kazakhstan, Alma-Ata), V. Yakovlyev (Moldova), etc.

We should emphasize that after the first research paper of these scientists. In Ukraine these were articles and later monographs by V. Muntyan, $\mathrm{N}$. Tytova which were dedicated to problems of collective farm and land law and legal protection of nature.

The number of papers which have not only scientific but also cognitive value has increased lately. They include summarizing courses on Ukrainian ecological law, published as collective and individual works (to the latter belong course books prepared by V. Andreytsev ${ }^{11}$ and M. Malyshko, also by Yaroslav the Wise National Law Academy with the help of A. Hetman, V. Popov and M. Shulha).

The concept "ecological law" in legislative practice has become universally known but at the same time it remains debatable in science. Thus, a Russian researcher, professor O. Kolbasov, whose contribution to development of ecological law theory is one of the most valuable, thought that in the legal system land, water, mountain, and forest law are absolutely equal inter se and with other branches but differ in the degree of development which is determined by certain historical conditions ${ }^{12}$. Stressing the fact that

11 Андрейцев В.І. Екологічне право: Курс лекцій в схемах. Загальна частина. - К.: "Вентурі", 1996. Andreytsev VI Environmental Law: Lecture Course in Schemes. The common part. - K. : Venturi, 1996.

${ }^{12}$ Колбасов О.С. Экология: политика - право. Правовая охрана природы в СССР. - М.: "Наука", 1976. - C. 146. Kolbasov O.S. Ecology: politics - law. Legal protection of nature in the USSR. - M. : "Science”, 1976. - P. 146. 
environmental protection as a complex universal problem is solved by facilities of all branches of law, O. Kolbasov suggested using terms "environmental protection (ecological) law" (which is maybe even efficient) for designation of certain directions of theoretical researches or educational disciplines, not associating the essence of these terms with the Soviet law system. In his opinion, yet it was impossible to prove the existence of the branch of environmental protection law at that time (in the 1970-ies). It was possible only to humbly speak about the tendency of formation of such a branch of law. The integrated branch of law the origin of which it is possible to expect, as a researcher wrote, should be named not "natural resources law", but "ecological law"13.

Ukrainian scholar Yu. Shemshuchenko claims that the essence of the corresponding branch of law is more precisely represented in the term "environmental law" than in the term "ecological law" ". Environmental law, in his opinion, has its own subject of legal regulation which is characteristic only of this branch. It is represented by numerous public relations in the sphere of cooperation of the society (the man) and environment that differ in certain content, but display organic and stable unity, i.e. ecological relations. In Yu. Shemshuchenko's opinion, there is commonness of the aim at the achievement of which public relations are directed by corresponding norms; they are the following: to provide harmonious cooperation of man and nature, to create environmental conditions favourable for person's life ${ }^{15}$. Complex character of legal regulation, commonness of aims and specificity of content prove to be, as the researcher thinks, an integral property of the legal community which appears in the form of an unusual and complex branch of environmental law. Its inner structure is composed by separate norms, institutes, and also branches of land, water, forest, atmospheric and faunistic law.

Another researcher V. Petrov consistently adhered to the term "ecological law", alluding to disagreement of participants of the scholarly discussion in 1987 with the "pro-western transcription" of the name of this discipline environmental law ${ }^{16}$. He pointed to a rather complex classification of norms of ecological law, to which he refers as behavioural, which regulate people's

${ }^{13}$ Колбасов О.С. Экология: политика - право. Правовая охрана природы в СССР. - М.: "Наука", 1976. - С. 155-156. Kolbasov OS Ecology: politics - law. Legal protection of nature in the USSR. - M. : "Science", 1976. - P. 146.

${ }^{14}$ Шемшученко Ю.С. Правовые проблемы экологии. - К.: Наук. думка, 1989. - С. 68. Shemshuchenko YS Legal problems of ecology. - K. : Sciences. Thought, 1989 - P. 68.

${ }^{15}$ Шемшученко Ю.С. Правовые проблемы экологии. - К.: Наук. думка, 1989. - С. 70. Shemshuchenko YS Legal problems of ecology. - K. : Sciences. Thought, 1989 - P. 68.

${ }^{16}$ Петров В.В. Экологическое право России. Учебник для вузов. - М.: БЕК, 1995. C. 5. Petrov V.V. Environmental Law of Russia. Textbook for universities. - M. : BEC, 1995. - P. 5. 
relations in the sphere of environmental protection and use; he divided them into three groups, and it is possible to agree with them:

- branch norms (protection and use of separate natural objects - land, bowels, waters, etc.);

- complex norms (protection and use of natural complexes, environment in general);

- ecologizational (norms of other branches of law that represent requirements of environmental protection).

According to ecological prescriptions V. Petrov divided ecological and legal norms into norms-principles, norms-priorities, and norms-rules:

- norms-principles contain principles of environmental protection;

- norms-priorities set legal advantages in the use and protection of certain objects. They, in turn, can belong to three levels: branch, inter-branch and general ecological levels;

- norms-rules contain ecological imperatives concerning a certain sphere of ecological relations. According to their content they are divided into preventive, prohibitive, recommencing, punitive, encouraging, authorizing, allowing, and obligatory ${ }^{17}$.

Origin and development of ecological law in Ukraine has resulted from objective requirements of the community development, it is a logical result of evolution of relations between society and nature within the framework of that type of community development which during decades has been formed in our state. Views on the content of this branch of law have evolved on the basis of corresponding public needs, practice of creation of the state.

At the same time development of ecological law in Ukraine was slowed by both factors of ideological character and substantial drawbacks of the law science which turned out to be absolutely unready to adequately comprehend needs of practice which developed quickly, by erroneous solutions to many ecologically meaningful questions, by nihilistic tendencies that denied even the possibility of existence of ecological law or substantially underestimated it.

In this respect the most important thing we should pay attention to is the speed of formation and intensity of development of Ukrainian ecological law, especially after 1986. First steps of the Soviet republic and later a separate state were expressed in the legal form, absorbing both achievements and mistakes of early years of Ukrainian independence. The first years of the Ukrainian state became the period of stormy legislative and generally lawmaking activity, formation and development of a number of new branches of law among which ecological law occupies one of the key positions.

${ }^{17}$ Петров В.В. Экологическое право России. Учебник для вузов. - М.: БЕК, 1995. C. 62-65. Petrov V.V. Environmental Law of Russia. Textbook for universities. - M. : BEC, 1995. - P. 62-65. 
Analogous examples are practically unknown to history when the basics of ecological law were created during several years. Practice has confirmed that legal norms are effective and reliable means of realization of social needs in ascertaining the optimal form of mutual relations between society and nature.

Today in Ukraine the conception of theoretical principles of development of separate branches of law has not been worked out yet. This also concerns ecological law.

The author of this textbook (V. Kostytsky) back in 1992 presented his own version of this conception and named it the conception of the "ecological tree". It contains a close list of necessary legal acts in the sphere of environmental protection; it represents cooperation and general principles of their preparation and development of the system of ecological law ${ }^{18}$.

According to this conception the "ecological tree" (see Fig. 1) is based on the Law of Ukraine "On Protection of Natural Environment" dated June $25^{\text {th }}$, 1991 in which constitutional statements in relation to environmental protection are reflected ${ }^{19}$.

The Constitution stipulates principles of Ukrainian ecological policy and duty of the state as for providing ecological safety. The Main Law of Ukraine sets guarantees of human rights to safe environment for life and health and lays a duty of compensation of the harm caused to the environment on all nature users (articles 50, 66). Every citizen has a right to use natural objects belonging to people's property (land, its bowels, atmospheric air and other natural resources which are within the limits of the territory of Ukraine, natural resources of its continental shelf, exceptional (marine) economic zone).

${ }^{18}$ Костицький В. Проблеми розвитку екологічного права України / Зб. тез: Екологічний менеджмент в Україні: порівняльний аналіз українського та західноєвропейського підходів. - 21-31 травня 1991р. - Женева. - 1991. - С. 161; Костицький В.В. Екологічне право України: деякі проблеми теорії та кодифікації // Право України. - 1998. - № 1. C. 67-72. Kostytsky V. Problems of development of environmental law of Ukraine / Coll. of theses: Environmental Management in Ukraine: A Comparative Analysis of Ukrainian and Western European Approaches. - May 21-31, 1991 - Geneva. - 1991 - P.161; Kostytsky V.V. Ecological law of Ukraine: some problems of theory and codification // Law of Ukraine. 1998. - № 1. - P. 67-72.

19 Костицький В. В. Екологія перехідного періоду: право, держава, економіка (економіко-правовий механізм охорони навколишнього природного середовища в Україні) / В. В. Костицький ; Інститут законодавчих передбачень і правової експертизи. К. : УСП МСБ "Еusmeu", 2003. - 772 с. - (Серія "Екологічна бібліотечка"; № 5) (Бібліотечка журналу "Малий та середній бізнес"). - C. 189-203. Kostytsky V.V. Ecology of Transition: Law, State, Economy (Economic and Legal Mechanism of Environmental Protection in Ukraine) / VV Kostytskyi; Institute for Legislative Predictions and Legal Expertise. - K.: USSB SME Eusmeu, 2003. - 772 p. - (Series "Ecological Library"; № 5) (Library of the magazine "Small and Medium Business"). - P. 189-203. 


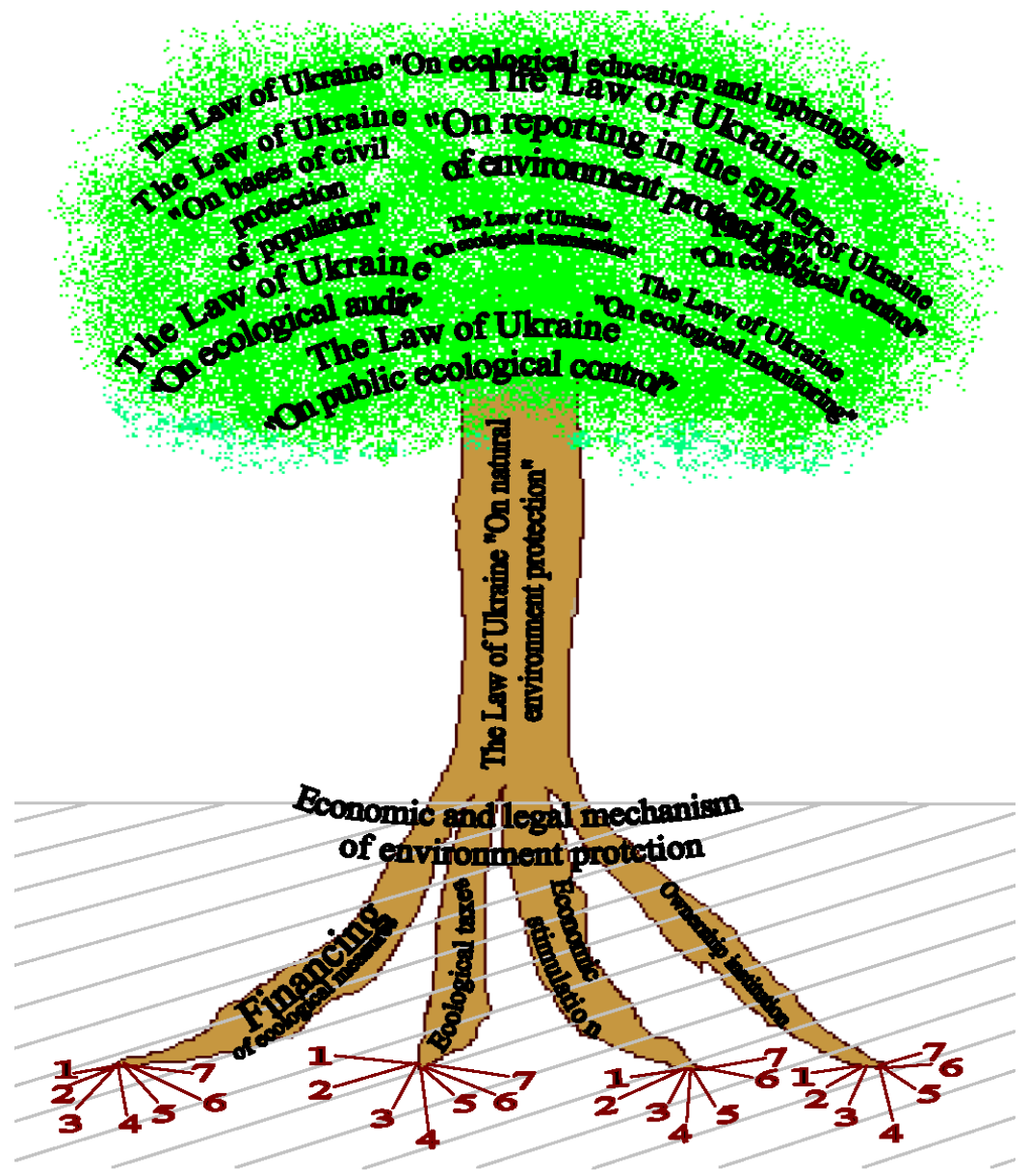

1 - Land law; 2 - Forest law; 3 - Water law; 4 - Bowels law; 5 - Atmospher protection law; 6 - Floristic law; 7 - Faunistic law;

Fig. 1. The "Ecological Tree"

The Law of Ukraine "On Protection of Natural Environment" determines general principles of environmental protection and is the basis of ecological law system. To innovations of this law one should include its structure, content and tasks. The most important here is the creation of legal terms for anti-pollution campaigns not against consequences, but reasons for 
anthropogenic and man-caused influence on the environment, beginning from technological processes. The system of ecological norms and standards is meant here. Thus, the law contains a list of ecological norms of maximum possible types of air pollution by stationary and movable sources; pollutants come into atmosphere from exploitation of technological and other equipment, buildings and objects; the law also describes norms of use of atmospheric air for industrial needs.

The "root system" of the "ecological tree" is presented by the acts of natural resources law - the Land, Forest, Water Codes of Ukraine, the Code of Ukraine on Bowels, laws on protection and rational use of flora and fauna, nature reserve fund, on air protection, and also by-laws to support the abovementioned laws. Input of economic and legal mechanism of exploitation of natural resources, which will be mentioned further, is one of the factors of viability of the "root system" of the "ecological tree". Legislative control of exploitation of natural resources, natural resources law is a basis which "holds" the "ecological tree" and simultaneously due to tax and financial law (constituents of economic and legal mechanism) "feeds" it, supports the effectiveness of all the system of ecological law.

The "crown" of the "ecological tree" is formed by legislative and normative acts of preventive character which like "leaves of a tree" play a "filter" role, preventing negative influence of human activity on the environment. It is, in particular, laws on ecological examination, status of zones of ecological emergencies, control in the sphere of environmental protection, statements about public ecological inspection, ways of spreading information on environmental protection, ecological monitoring and other legal acts, i.e. legislation which makes the basis of ecological safety without which the "ecological tree" will "dry up", and economic and legal mechanism of environmental protection will not work (see Fig. $2^{20}$ ).

Today it is possible to claim that the "ecological tree" has already "grown" in Ukrainian legislation; in our state the national system of ecological law was formed as a complex branch of law which includes legal norms and legal relations that arise in the process of cooperation of society and nature.

20 Костицький В. В. Екологія перехідного періоду: право, держава, економіка (економіко-правовий механізм охорони навколишнього природного середовища в Україні) / В. В. Костицький ; Інститут законодавчих передбачень і правової експертизи. К. : УСП МСБ "Еusmeu”, 2003. - 772 с. - (Серія "Екологічна бібліотечка" ; № 5) (Бібліотечка журналу "Малий та середній бізнес"). - C. 189-203. Kostytsky V.V. Ecology of Transition: Law, State, Economy (Economic and Legal Mechanism of Environmental Protection in Ukraine) / VV Kostytskyi; Institute for Legislative Predictions and Legal Expertise. - K.: USSB SME Eusmeu, 2003. - 772 p. - (Series "Ecological Library"; № 5) (Library of the magazine "Small and Medium Business"). - P. 189-203. 


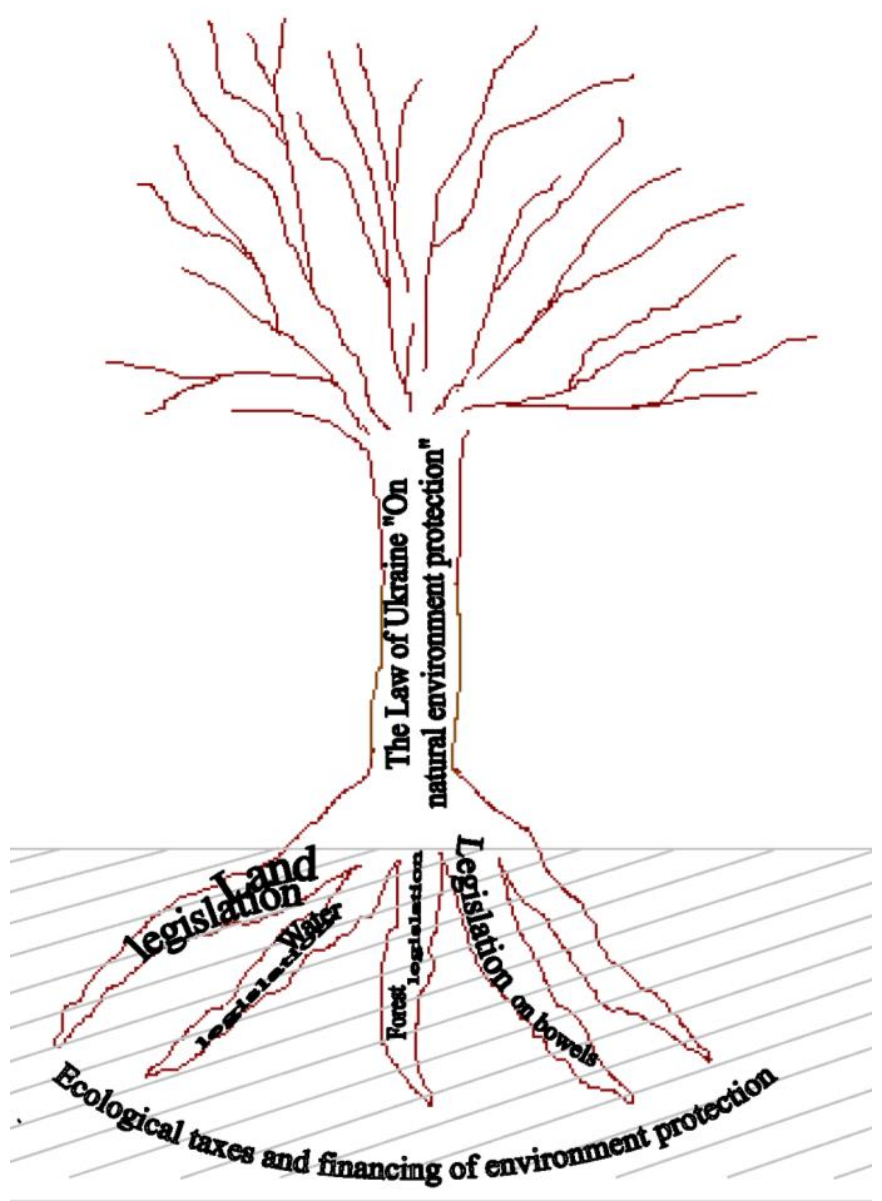

Fig. 2. The "Ecological Tree" in Case of Absence of the Institute
of Ecological Safety

Therefore, the first stage of conception of the "ecological tree" which today looks somewhat naive has been realized. Nowadays it is necessary to provide ecologization of other branches of legislation, to adopt a law on ecological education $^{21}$, worked out with author's input back in 1992, to

${ }^{21}$ Костицький В.В. Програмне забезпечення еколого-правової підготовки інженерних кадрів // Рад. право. - 1989. - № 10; Костицький В.В. Організація безперервного екологічного виховання / Зб.: Географічні системи природокористування Волині. Тези 
initiate in its accordance an obligatory ecological qualifying minimum for all government officials and enterprise workers, i.e. nature users. Unfortunately, today in questions of ecologization of legislation we stand farther than twelve years ago when even without legislative requirement all regulatory legal acts were examined by the Ministry of Protection of Natural Environment of Ukraine (now the Law of Ukraine "On Ecological Examination" is in effect). However, we became witnesses of both ecological nihilizm in the law-making sphere and revisionism which showed itself in attempts of liberalization of requirements to ecological safety and liberal changes in the Law of Ukraine "On Protection of Natural Environment".

Ukrainian legal idea still has to find optimal principles of cooperation and differentiation of branches of law. Obviously, nowadays we should display patience and consideration, remembering that one or few legislative acts do not provide coordination and efficiency of public relations. A number of laws seem necessary, something similar to the "critical mass" in physics to make all the legal system "begin to work". Even within the limits of one branch of law it is difficult to obtain necessary effect without corresponding innovations in other branches of law. For instance, insufficient effectiveness of the Law of Ukraine "On Protection of Natural Environment" is largely stipulated by delay of alterations to the Code on Administrative Offences of Ukraine and absence of law on state control in the sphere of environmental protection.

Today we face the necessity of codification of ecological law and adoption of the Ecological Code of Ukraine which would take into account recent achievements not only of the law science but also of law-making and lawenforcement practice.

Nowadays ecological law in Ukraine has been finally formed as an independent branch of law. It represents generalized interest, legalized public need in maintenance, rational use and recreation of natural resources, protection of landscapes, ecosystems and environment on the whole as conditions of further existence of the human civilization ${ }^{22}$.

\section{Principles of Ecological Law}

Considering the legislative system as a holistic phenomenon, the author notes that the principles of legislation, along with the subject and method of legal regulation, are the criteria for delimiting the branches of legislation. The

\footnotetext{
доповідей. - Луцьк. - 14-16 лютого 1994 р. та ін. Kostytsky V.V. Software for environmental legal training of engineering personnel // Rad. right. - 1989 - № 10; Kostitsky V.V. Organization of continuous ecological education / Coll.: Geographic systems of nature management in Volyn. Abstracts. - Lutsk. - February 14-16, 1994 and others.

${ }^{22}$ Костицький В.В. Лісове право України. - К., 1999. - С. 10. Kosthtsky V.V. Forest Law of Ukraine. - K., 1999. - P. 10.
} 
principles of legislation are peremptory legal norms enshrined in the Constitution and laws of Ukraine, due to the objective needs of the legal regulation of public relations.

The principles of environmental (ecological) legislation express the main objective laws of the mechanism of interaction between the individual, society and the natural environment of a person and determine the essence of environmental legislation.

The principles of environmental legislation are an expression of public environmental interests, and operate within all sub-sectors and institutions of environmental legislation, are enshrined in the relevant provisions of the laws, act as the most concentrated supremacy of the principles of environmental law, and interact with the principles of environmental policy.

Defining the system of principles of environmental legislation of Ukraine as an integrated unity of environmental and legal guiding ideas that have a generally binding character, relative independence, and the ability to interact with other elements of the system, the author sees this as the source of the creation of an environmental legal order.

The work focuses on the fact that in modern science, in theoretical and methodological terms, there is no consistent delimitation of the principles of environmental legislation on industry, sub-industry and institutional, there is excessive declarativeness in their formulation. As a result, the potential of using sub-industry and institutional principles of environmental legislation to implement the constitutional principles of environmental protection is underestimated.

The author joins the opinions expressed in the legal literature that the principles of environmental legislation of a regulatory and protective nature are not equally enshrined in the legislation, and therefore an important task of theoretical science is the requirement for the correct formulation of these principles, taking into account their integrative nature and importance for structuring environmental legislation.

Principles of ecological law consist in fundamental ideas, basic principles, peculiarities, properties which are typical of all legal norms of ecological law, according to which regulation of ecological relations is carried out. From our point of view, the above-mentioned list of features has to be definitely complemented by such characteristics as requirements. Primarily, principles are nothing else but requirements in accordance with which certain legislative norms must be reflected in corresponding acts. Principles are the basis of construction and functioning of law, de facto they are obligatory in the part of inhibition for all the subjects of ecological relations without exception; their current state de jure determines the level of legal consciousness and culture of the society, in the part of the subject of research - a level of its ecological 
behaviour. Principles of ecological law are characterized by the process of permanent development the dynamics of which is determined by transformation of tasks in the sphere of exploitation of natural resources, environmental protection and providing ecological safety in conditions of increased changeability of the environment, the system of ecological relations, largely predefined by the change of ecological requirements on national and international levels.

Principles of ecological law apart from its object and methods of legal regulation of ecological relations are criteria which allow to distinguish ecological law from other branches of law, to determine the nature of ecological law as a complex branch of law.

In scientific works structuring principles of ecological law is carried out by their systematization into basic groups and also by singling out basic principles inside each of such groups.

First of all, ecological law is based on the system of general (which determine the essence of law on the whole - principles of social justice and social freedom, equality (equal protection of the law), unity of legal rights and duties, lawfulness, inevitability, etc.) and special (branch-related - which concern and operate within the limits of one branch) principles. At the same time differences in approaches of a number of scientists take place in the part of systematization of basic principles of ecological law.

$\mathrm{Yu}$. Shemshuchenko, in particular, distinguishes the following basic principles of ecological $\operatorname{law}^{23}$ : consistency and complexity in regulation of ecological relations; order of precedence of citizens' rights to the environment safe for life and health (Article 50 of the Constitution of Ukraine, Article 9 of the Law of Ukraine "On Protection of Natural Environment"); prevention of ecological harm (Article 3 of the Law of Ukraine "On Protection of Natural Environment"); combination of rights and duties, stimulation and liability in the sphere of action of ecological law (articles 55 and 66 of the Constitution of Ukraine, Article 3 of the Law of Ukraine "On Protection of Natural Environment").

Meanwhile, A. Hetman and A. Shulha ${ }^{24}$ distinguish the following principles of ecological law: principle of legal support of achieving

${ }^{23}$ Екологічне право України. Академічний курс: Підручник. - Друге видання / За заг. ред. Ю.С. Шемшученка. - К.: ТОВ “Видавництво "Юридична думка", 2008. - 720 с. Environmental Law of Ukraine. Academic course: Textbook. - Second edition / For the head. ed. Yu.S. Shemshenko. - K. : LLC "Legal Thought Publishing House, 2008. - 720 p.

${ }^{24}$ Гетьман А.П., Шульга М.В. Екологічне право України: Підручник. - Харків.: Право, 2005. - режим доступу до інформації: http://ebk.net.ua Getman A.P., Shulga M.V. Environmental Law of Ukraine: Textbook. - Kharkiv: Law, 2005. - mode of access to information: http://ebk.net.ua 
harmonious cooperation of society and nature (as the main principle); principle of legal support of ecological safety; principle of legal record of belonging of natural resources to certain legal subjects and their use with the aim of satisfaction of ecological, property and other interests within the limits of legislation; principle of legal support of rational and effective use of natural resources; principle of legal support of proper use of natural objects; principle of legal support of stimulating proprietors and users of natural objects to properly use natural resources, recreate and protect them; principle of legal support of stable (long-lasting) use of natural resources; principle of legal support of a complex approach to use and recreation of natural resources and to environmental protection.

While classifying principles of ecological law it seems reasonable to follow the approach formulated by A. Hetman and A. Shulha, according to which "classification of ecological and legal principles... has to be based on ecological legislation or derive from its content. Without taking this factor into account proclaimed principles become declarations of the state or the author of these principles" 25 .

Considering the above-mentioned ideas, it is logical to appeal to principles of protection of natural environment, proclaimed in Article 3 of the Law of Ukraine "On Protection of Natural Environment".

Principles reflected in the given law directly concern ecological law because this is the latter by which ecological activity as a specific sphere of public relations is regulated.

However, since the Law of Ukraine "On Protection of Natural Environment" was adopted many years have passed and today we can talk about a new system of principles of ecological law to which belong the following: priority of requirements of ecological safety, obligatoriness of inhibition of ecological standards, norms and limits of use of natural resources in the activity of public and local self-government bodies, and also in the process of realizing economic, administrative, humanitarian, social and other activity; duty of the state to guarantee the environment ecologically safe for life and health of people, to provide favourable ecological conditions of person's work and rest; realization of the principle of prudence in planning or introduction of any measures which presupposes warning or minimization of risk or danger of negative influence on the environment; realization of the principle "a polluter pays" in legislative activity and law enforcement of the

\footnotetext{
${ }^{25}$ Гетьман А.П., Шульга М.В. Екологічне право України: Підручник. - Харків.: Право, 2005. - режим доступу до інформації: http://ebk.net.ua Getman A.P., Shulga M.V. Environmental Law of Ukraine: Textbook. - Kharkiv: Law, 2005. - mode of access to information: http://ebk.net.ua
} 
state, in other words the introduction of paid access for industrial and economic activity which leads to environmental pollution and worsening the quality of natural resources, introduction of ecological taxes; solution to problems of environmental protection on the basis of wide intergovernmental collaboration; subsidiarity of ecological policy of the state, in other words application of international norms and rules in ecological policy of the state if they appear to be more effective than national ones; ecological patriotism, realization of economic, political, humanitarian, social and other activity taking into account ecological interests of Ukraine, priority for society of life supporting (social, recreational, protective) functions of biosphere concerning direct (raw material) use of natural resources, use of national standards, if their requirements are more effective for achievement of tasks of environmental protection than international ones; principle of integration in realization of ecological measures of the state; basinal approach to management in the sphere of environmental protection, guard and use of natural resources; citizens' right to participate in realization of public ecological policy; compensation of harm and losses caused by violation of legislation on environmental protection.

Application of any principle of environmental protection cannot lead to violation of the other principle or person's right to ecological safety and environmental protection.

\section{CONCLUSIONS}

Moral and ecological ethics are at the heart of making any environmentally sound decisions. The question of salvation of modern civilization lies in the field of environmental ethics, including through the adoption and implementation of the Earth's Ecological Constitution. The international legal environmental imperative (the moral imperative of good), as an ideal to which we would all strive together to preserve the Earth for our children and grandchildren, must obviously be the content of the Earth's Ecological Constitution, which should precede the harmonization of the constitutional consolidation of human rights. living in a favorable environment and other environmental rights as a condition and obligation of the state to ensure sustainable development and carry out an ecological function in accordance with the requirements of international and national environmental law.

The components of the development of law should be not only the further progress of environmental science, the enhancement of the ecological and legal culture, the improvement of the eco-legal education system, but, above all, the improvement of the legislation, taking into account the normative force of the law, its general binding nature. We now face the need to codify 
environmental legislation and adopt the Environmental Code of Ukraine, which would take into account the latest developments in both legal science and law-making and law enforcement. Such a need is also objectively attributed to the fact that it is now generally accepted to distinguish environmental law as a complex branch of law, which brings together a relatively independent set of rules of law governing certain spheres of social relations, united in separate branches, sub-branches and institutions of law.

The codification of environmental law must be carried out at the level of creation of new rules of law. After all, a legal rule - a specific rule of conduct, established or sanctioned and enforced by the state - is the least structural component of the environmental law system. The rule of law can be compared to a molecule of a substance that is known to be the smallest constituent of a substance that retains the properties of that substance. A water molecule is water, and two hydrogen or oxygen atoms have different properties compared to water. The rule of law is the smallest piece of law that holds the properties and features of law. The most striking feature of this law is manifested in environmental law, which combines legal rules aimed at preserving the environment in which a person lives.

Therefore, environmental law is a complex area of law that regulates legal relations in the field of nature protection, rational use of natural resources and ensuring environmental safety, that is, relations related to environmental protection in general, protection and use of natural resources and protection of life and health. human beings due to the negative impact of human activity on the environment in order to ensure a balanced sustainable development for the benefit of present and future generations of people.

The criteria for the "identification" of environmental law in the legal system are the public inquiry caused by the imminent global ecological crisis, as well as the identification of the subject, methods of regulation of social relations and environmental principles.

As a result, the tendency for the rapid development of both international environmental law and national environmental legislation was established, accompanied by an unprecedented phenomenon - the mutual "flow" of progressive environmental ideas between national and international environmental law.

The highest achievement here should be considered the constitutional fixing in a number of countries of the natural human right to life and to the environment, other environmental rights that flow from it (Constitution of the Republic of Tataria, Article 35 of the Charter of Fundamental Rights and Freedoms of the Czech Republic, the Constitution of Estonia, Macedonia, Moldova, Slovenia, Russian Federation). 
The human right to a clean environment in the constitutions of modern states is considered to be the legal basis for the legal consolidation of the ecological function of the state. In this way, preserving the environment for present and future generations in modern law theory and constitutional practice is seen as a shared responsibility of the state, civil society and man. This approach can be defined as an international legal environmental imperative, which is accepted in almost every country in the world.

Further development of the Institute for Environmental Rights and Freedoms should take into account the emerging trends of mutual" transfusion "of scientific ideas and provisions between national legislation and international environmental law, especially the processes of globalization. It has become generally accepted the constitutional consolidation of environmental responsibilities of citizens, which corresponds to the environmental right to a life-friendly and clean environment. We note here the experience of the Czech Republic, whose constitution shared the obligation to perform an ecological function between the state and civil society.

Such provisions are enshrined directly or indirectly by the constitutions of Austria, Macedonia, Moldova, Portugal, Slovenia, Hungary, Ukraine. The constitutions of the Republic of Belarus, Macedonia, Moldova, the Russian Federation, Slovenia and Uzbekistan proclaim the duty of everyone to protect the natural environment.

A number of constitutions of modern states have implemented international principles that have become the property of modern science and international practice. This applies not only to the human right to environmental information, but also to the principle of sustainable (stable) development as fundamental to ensuring environmental safety and the realization of the human right to an environment conducive to life and health. Thus, in order to realize the human right to live in an environment of ecological balance, the Portuguese Constitution is obliged to develop the rational use of natural resources, preserving their capacity for renewal and environmental sustainability, to promote balanced socio-economic development, to develop a national energy policy aimed at the conservation and conservation of natural resources equilibrium.

\section{SUMMARY}

Globalization implies the creation of a new environmental ethic in the global civil society of the post-industrial era. The ethics of global civil society will be guided by the priority of human interests, the desire to preserve and pass on the Earth and modern civilization to the next generations. Man in the 21 st century, like modern society as a whole, continues to be as integral to nature as it was centuries and millennia ago. Global civil society is 
accompanied by the transformation of man into a citizen of the world and the affirmation of the dominant environmental rights and freedoms of the individual as a condition for the development of modern society.

\section{REFERENCES}

1. Alekseev S.S. Right. Alphabet. Theory. Philosophy. Experience in complex research. - M.: Charter, 1999.

2. Andreytsev V.I. Environmental Law: Lecture Course in Schemes. The common part. - K : Venturi, 1996.

3. Ecological Constitution of the Earth. Methodological basis / [V.V. Kostytsky et al. in a row. Acad. NAS of Ukraine, Doctor of Economics. of sciences, prof. Tunisia]. - Lviv: RVV NLTU of Ukraine, 2011. P. 370-381.

4. Environmental Law of Ukraine. Academic course: Textbook. - Second edition / For the head. ed. Yu.S. Shemshenko. - K : LLC "Legal Thought Publishing House, 2008. - 720 p.

5. Hegel GVF Philosophy of Law. - M.: "Thought", 1990.

6. Hetman A.P., Shulga M.V. Environmental Law of Ukraine: Textbook. - Kharkiv: Law, 2005. - mode of access to information: http://ebk.net.ua.

7. Kolbasov O.S. Ecology: politics - law. Legal protection of nature in the USSR. - M.: "Science", 1976.

8. Kostytsky V.V. Ecological law of Ukraine: some problems of theory and codification // Law of Ukraine. - 1998. - № 1. - P. 67-72.

9. Kostytsky V.V. Ecology of Transition: Law, State, Economy (Economic and Legal Mechanism of Environmental Protection in Ukraine) / V.V. Kostytskyi; Institute for Legislative Predictions and Legal Expertise. K.: USSB SME Eusmeu, 2003. - 772 p.

10. Kostytsky V.V. Forest Law of Ukraine. - K., 1999.

11. Kostytsky V.V. Methodological problems of codification of environmental legislation / V. Kostytsky // Small and medium-sized business (Law, State, Economics). - 2011. - № 3-4. - P. 3-6.

12. Kostytsky V.V., International legal ethical imperative as the basis of theoretical and methodological support for the development of environmental law / V. Kostytskyi // Law of Ukraine. - 2011. - № 2. - P. 20-33.

13. Kostytsky V. Problems of development of environmental law of Ukraine / Coll. of theses: Environmental Management in Ukraine: A Comparative Analysis of Ukrainian and Western European Approaches. May 21-31, 1991 - Geneva. - 1991.

14. Kostytsky V.V. Software for environmental legal training of engineering personnel // Rad. right. - 1989 - № 10. 
15. Protasov V.F., Molchanov A.V. Dictionary of environmental terms and concepts. - M., 1997. - P. 101.

16. Rabinovich PM Human rights and their legal support (foundations of the general theory of law and state). - K., 1992. - P. 7.

17. Shemshuchenko Y.S. Legal problems of ecology. - K: Sciences. Thought, 1989.

Information about the author: Kostytsky V.,

Doctor of Law (DrSc.), Professor, President of the International Environmental Academy ORCID: 0000-0003-1692-9810 


\section{THE PECULIARITIES OF THE STATE REGULATION OF THE TERRITORIAL INTERCOURSE IN THE COUNTRIES OF THE COMMONWEALTH OF INDEPENDENT STATES}

\section{Stratonov V. M., Gavlovskaya A. O., Pavlish P. V.}

\section{INTRODUCTION}

The investigation of the state regulation of the territorial intercourse in the countries of CIS is based on the theoretical notion "the state regulation of the economical intercourse" that is related to the territorial intercourse.

The given notion is identified in different ways by various scholars. Thus, this notion is identified as:

- the state regulation of the economical business, namely, the influence of the state in a person of the state agency on economical objects, processes and personalities that take part in such a business including the prognostication, the planning, the financing, the budgeting, the taxation, the administration, the accounting and the control ${ }^{1}$;

- the state regulation of the economics as the system of activities for the creation of the supporting, the compensational, the regulative activity of the state leaded on the creation of the normal conditions of the effective functioning of the market and the solvation of complex social and economic problems of the development of the national economics and the whole society $^{2}$;

- the state regulation of the economics is the regulation of the economics by means of the direct and the indirect intervention (the direct intervention is the acceptance of the legislative acts aimed on the ordering and the development of the business between all the elements of the market system; the indirect intervention comprises various ways of the economical politics depending on the aim of the intervention $)^{3}$.

Thus, the state regulation of the economics is identified in the scientific paradigm as the influence on the economic intercourse with the help of the direct and the indirect action by means of the system of activities of the state agencies.

${ }^{1}$ Борисов А.Б. Большой экономический словарь / А.Б. Борисов. М.: Книжный мир, 2003. C.283.

2 Стеченко Д.М. Державне регулювання економіки: Навч. посіб. 3-тє вид., випр. Рекомендовано МОН / Д.М. Стеченко. К., 2006. С.189.

3 Прямое и косвенное государственное регулирование экономики. URL: http://econtool.com/gosudarstvennoe-regulirovanie-ekonomiki.html.(дата звернення 12.02.20) 


\section{The State Regulation of the Territorial Intercourse in the Countries of the Commonwealth of Independent States (CIS)}

It should be mentioned that there is the difference between the scientific identification on the notion "the state regulation of the territorial intercourse". L.A. Shwayka states that the state regulation of the territorial intercourse is "the creation of the legislative basis on the protection of rights of the territoryowners and the territory-users in the choice of the effective proportions between the direct and the indirect administration of the territorial recourses"4.

O.S. Damdin points out that the state regulation of the territorial intercourse "leaded on the organization of the rational usage of the territory and it's protection by means of the creation of rules and norms of the possession, the usage and the order of the territorial recourses of the state". N.I. Kalinin states that the state regulation of the territorial intercourse is "the purposeful activity of state agencies of the organization of the rational usage of lands and their defense by means of the usage of the economical and the legal activities",

Summarizing the above mentioned definitions we propose the following identification of the state regulation of the territorial intercourse as the purposeful activity of the state agencies of the legal, of the economical and of the organizational nature that is aimed on the regulation of the business in the sphere of the rational usage of lands, their protection, the defense of rights of the territory-owners and the territory-users.

On the basis of the given definition we point out the following objective reasons of the necessity of the state regulation of the territory intercourse: the peculiar multifunctional role of the territory in the life of a society; the natural restriction and the irreplaceability of the land; the rational usage of the territory; the protection of rights and interests of subjects of law; the elimination of negative results of the market processes in the sphere of the territorial business; the protection of the state and the national interests; the creation of the effective conditions for the functioning of the territorial market; the creation of the state and the social needs and priorities of the development; the providing of the security and the protection of the state; the need of "the balancing" of the direct and the indirect methods of the state regulation of the territorial intercourse and so on.

4 Швайка Л.А. Государственное регулирование экономики: Учебное пособие / Л.А. Швайка. К.: Знание, 2006. С. 156.

${ }^{5}$ Дамдын О.С. Государственное регулирование земельных отношений / О.С. Дамдын // Молодой ученый, 2011. № 5. Т. 1. С. 175-177.

6 Калинин Н.И. Правовое регулирование земельных отношений в России / Н.И. Калинин. М.: Кооперационный проект "Германо-Российский аграрно- политический диалог", 2011. С. 2. 
Among the variations of the state regulation of the territorial business are identified the following types:

1. The regulation of the territorial intercourse by the state as the sovereign that has the territorial priority on all the territories in spite of the forms of the ownership. The Constitutional basis of such a kind of the state regulation of the territorial intercourse is defined by the majority of Constitutions of CIS. For example, according to the Article 55 of the Constitution of Kazakhstan Republic "the land, it's subsoil, water, floral and animal world and other natural resources are the national wealth and should be used rationally and are protected by the state". The Article 13 of the Constitution of Tajikistan Republic is the evidence that "the land, it's subsoil, water, air space, floral and animal world, and other natural resources are the property of the state and the state guarantees the effective usage according to the interests of the nationality" ". In the Point 5 of the Article 12 of the Constitution of Kyrgyzstan Republic is pointed out that "the land, it's subsoil, air space, water, forests, floral and animal world and other natural resources are the property of Kyrgyzstan Republic and are used for the safe of the ecological system as the basis of life and activity of the nationality of Kyrgyzstan Republic and are protected by the state" 8 .

The conclusion: the objective need of the regulation of the territorial business by the state as the sovereign is determined by the fact that the land as the basis of the life of nationalities is the property of the state and is protected by it.

2. The economic regulation of the territorial intercourse is made by the state agencies as the economic subjects that have the power to give land properties to physical and judicial personalities, lead the accounting, the evaluation, the protection of lands etc ${ }^{9}$. For example, the evaluation of land resources in Moldova Republic is made by the Parliament on the basis of the acts of the Law of Moldova Republic "The Normative Price and the Order of the Buying-Selling of Land Properties” № 1308 - XIII dated by 25.07.1997: rates for the calculation of the normative price are identified by the conditional unit - the ball-hectare according to the inventory (quantitative and qualitative) results according the appendix that is the part of the mentioned law and is rated annually by the Parliament as for the presentation of the state

7 Конституція Республіки Таджикистан від 06.11.1994. URL: http:// www.tajikistan.turkestan.ru/constitution/. (дата звернення 02.02.2020)

${ }^{8}$ Конституція Киргизької Республіки від 05.05.1993. URL: http://www.gov.kg/?page_id= 263\&lang=ru. (дата звернення 02.02.2020).

9 Дамдын О.С. Государственное регулирование земельных отношений / О.С. Дамдын // Молодой ученый. 2011., № 5., Т. 1. С. 175. 
while the approval of the state budget according to the level of the inflation" (Point 2, Article 2) ${ }^{10}$.

The example of the pointing out of the protection of lands in the state may be Point 1 in Article 139 of the Territorial Code of Kazakhstan Republic "the protection of lands comprises the system of legal, organizational, economic, technical and other activities leaded on the protection of lands as the part of the ecosystem, the rational usage of territories, the liquidation of the non-legal exclusion of lands from the agricultural and the forest circulation and the revival and the increasing of the futility of soils"11.

As O.S. Damdin states: "the state regulation of territories is subdivided on the general - that is done by the state agencies of the common and the special competencies and that is widespread on all categories of lands and all subjects of territorial intercourse; the industrial - that is made by ministries and committees and federal agencies based on the principle of the accountability of industries and organizations that are responsible for the giving of rights of land properties" $"$. The example of the general state regulation of territories is given in Chapter 2 of the Code of Belorussia Republic concerning the state regulation of the territorial business in Belorussia by "the President of Belorussia, the Cabinet of Ministers of Belorussia, the State Committee of the Land Property of Belorussia and other specially administrated republican agencies of the state intercourse, the regional, The Minsk urban, the urban (belonging to towns of the regional administration), regional, rural, rural and urban administrative committees according to their competences that are regulated by the Code and other Acts of Legislation"13.

Thus, the State Property Committee of Belorussia is active in the regulation of territorial intercourse on the basis of "the state regulation and the administration in the sphere of usage and protection of lands while the regulation of the order of the elimination and the giving of territorial areas, the transformation of land areas from one category to another" ${ }^{\prime \prime}$. The competence of the State Committee of Land Property in Belorussia in the sphere of usage and protection of lands leads the

10 Закон Республики Молдова "О нормативной цене и порядке купли-продажи земли" № 1308-XIII от 25.07.1997. URL: http://www.casa-ta.info/zakon/zakon4.php?lang=ru. (дата звернення 02.02.2020).

11 Земельний кодекс Республіки Казахстан від 20.06.2003 г. № 442-II. URL: http://online.zakon.kz/. (дата звернення 02.02.2020).

12 Дамдын О.С. Государственное регулирование земельных отношений / О.С. Дамдын // Молодой ученый. 2011., № 5., Т. 1. С. 176.

13 Кодекс республіки Білорусь про землю від 23.062008 г. № 425-3. URL: http://www.etalonline.by/?type=text\&regnum=Hk0800425\#load_text_none_1_6 (дата звернення $02.02 .20)$

${ }^{14}$ Официальный сайт Государственного комитета по имуществу Республики Беларусь. URL: http://www.gki.gov.by/ru/activity_branches-land/. (дата звернення 02.02.20). 
state policy, administrates the order as for the revival, the pointing out, the fixing of borders of land areas, provides the development of projects of regional systems of usage and protection of land resources, schemas of the land administration of the administrative and the territorial unities, points out the order of the leading of the land management, organizes it's leading and so on (Article 26. The Code of Belorussia about Lands) ${ }^{15}$.

In Ukraine the agencies of the local administration (regional, Kiev and Sevastopol municipal, regional, regional in towns, rural, rural and urban council) perform the administrative functions in the sphere of the territorial intercourse according to Articles 8-12 TC of Ukraine, Laws of Ukraine "The Urban Municipality in Ukraine" dated by the $21^{\text {st }}$ of May 1997 (with the corresponding changes), "The Capital of Ukraine - the Heroic Town Kiev" dated by $15^{\text {th }}$ of January 1999 . To their sphere of responsibility belong: the administration of lands of territorial municipalities; the creation of conclusions as for elimination (buying) and giving land areas from the state lands by means of agencies of the administrative power; the regulation and the change of borders of the corresponding administrative and territorial units; the organization of the land management; the provision of the realization of the state policy in the sphere of the usage and the protection of lands etc. The peculiarity of the state industrial regulation of lands is the inner-industrial administration of lands is made by industries and organizations that own lands. For example, agencies give normative acts in the sphere of the administration of lands that are obligatory for the realization in the sphere of the judicial person and are accompanied by actions of the disciplinary acts. The process of the legal regulation of the territorial intercourse is made on the basis of regulative and protective and warning norms.

The basis of the legal regulation of the territorial business is "the rational usage of territorial resources in CIS" that is guaranteed by different complexes of legal actions, such as:

1. The stimulation of the purposeful usage of territorial areas:

a) the charge of the land management (for example, "land areas that are the property are rated by the territorial tax according to the taxing laws of Kazakhstan Republic" - Article 9 of The Territorial Code of Kazakhstan Republic) ${ }^{16}$;

15 Кодекс республіки Білорусь Про землю від 23.062008 г. № 425-3. URL: http://www.etalonline.by/?type=text\&regnum=Hk0800425\#load_text_none_1_6 (дата звернення $02.02 .20)$

${ }^{16}$ Декларація про принципи міжнародного права, що стосуються дружніх відносин та співробітництва між державами відповідно до Статуту Організації Об'єднаних Націй від 24.10.1970. URL: http://zakon4.rada.gov.ua/laws/show/995_569/card2\#Card (дата звернення 02.02.20) 
b) the usage of benefits and advantages to owners and land managers (for example, "the provision of benefits of the land tax that are explored firstly and lands of irrigation that are in the process of the ameliorative improvement according to the legislative acts", - Article 83 of The Territorial Code of Uzbekistan Republic) ${ }^{17}$;

c) the usage of sanctions towards people who violate the process of the usage of lands (for example, "administrators, owners of land areas and land managers are responsible for the regulated by the law of Kirgizstan Republic social, administrative and criminal responsibility for the violation of the territorial laws" Article 120 of The Territorial Code of Kirgizstan Republic) ${ }^{18}$.

2. The ways of the elimination of reasons and conditions that cause the irrational usage of land areas:

a) the regulation of the state system of the giving and the elimination of lands (for example, "the right of the private property on territorial areas is withdrawn according to the court decision while the confiscation of the land area" - Article 80 of The Territorial Code of Belorussian Republic) ${ }^{19}$;

b) the regulation of the need to correspond the ownership of land areas with the proper state agencies (for example, "the giving of the judicial persons of Turkmenistan territorial areas for the development of the useful resources is made after the formation of the mountain management with the condition of the further remediation of the areas and according to the laws of Turkmenistan in the sphere of nature protection" Article 85 of The Territorial Code of Turkmenistan",20;

c) the creation of the scientifically proved calculations that illustrate the consequences of the usage of the given lands (for example, "the protection of lands is done with the help of the usage on practice scientifically proved norms of the land usage that reflect the optimal structure of the usage and the effective organization of the territory on the basis of the land management" Part 2, Article 34 of The Territorial Code of Azerbaijan ${ }^{21}$.

3. The way of the pointing out of the operative stopping of the national of the land areas (for example, "in cases when the agency has ordered to

17 Земельний кодекс Республіки Узбекистан від 30.04.1998 № 598-I. URL: http://www.lex.uz/pages/GetAct.aspx?lact_id=149947. (дата звернення 02.02.20).

18 Земельний кодекс Киргизької Республіки від 02.06.1999 № 46. URL: http://online.adviser.kg/Document/?doc_id=30241294. (дата звернення 02.02.20).

19 Кодекс республіки Білорусь про землю від 23.06 2008 г. № 425-3. URL: http://www.etalonline.by/?type=text\&regnum=Hk0800425\#load_text_none_1_6. (дата звернення 02.02.20).

20 Кодекс Туркменістану “Про землю”. URL: http://parahat.info/law/kodeksturkmenistana-o-zemle. (дата звернення 02.02.2020).

21 Земельний кодекс Азербайджанської Республіки від 16.07.1996 № 695-IQ. URL: http://eco.gov.az/az/435-azerbaycan-respublikasinin-torpaq-mecellesi. (дата звернення 02.02.20). 
withdraw reasons of the irrational usage and the protection of lands it has the right to make the checking of the mentioned actions in the regulated term" Article 85 of The Territorial Code of Uzbekistan) ${ }^{22}$.

4. The way of the regulation of the withdrawal of violations of the rational usage of lands (for example, "the protection of lands comprises from the system of legal, organizational, economic and other activities made with the purpose of their rational usage, protection and the unproved withdrawal of the more valuable lands from the circulation of the agriculture and the forest household, the protection from the harmful natural and anthropogenic actions and the revival and the increasing of the futility of lands and forests" - Part 1, Article 34 of The Territorial Code of Azerbaijan).

As a conclusion, the legal provision of the rational usage of lands as the basic way of the legal regulation of the territorial intercourse is the complex of legal actions the systematic usage of which lets to solve tasks of the land policy of the country of CIS. It should be mentioned that while the regulation of different ways of the territorial intercourse and on the basis of the subdivided legal regulation of the Territorial Code of CIS divide spheres of the activity of the land laws, laws about the protection of the environment and the rational usage of the natural resources, etc.

This principle lets optimally to regulate the territorial intercourse with the actualization of the peculiarities of the object of the business and their ecological relations with other natural objects.

Among the problems of the state regulation of the territorial business should be mentioned the following problems: the old territorial legislation in the sphere of the state regulation of the territorial intercourse that doesn't correspond to the modern development of the social and the economic intercourses in the state; "the ramified" system of the state agencies in the sphere of the state regulation of the territorial intercourse; the problem of the correlation between state agencies of different levels and spheres of the influence on the territorial business (for example, the interrelation between agencies that control the information about territorial areas and agencies that form rights on them ${ }^{23}$; the dubbing of functions of state agencies (for example, the repetition of identical items of the inventory accounting); the absence of the united system of the accounting, the safe and the usage of the informational resources as for the land areas; the concentration of the great variety of land areas in some great structures (latifundists); the great level of

22 Земельний кодекс Республіки Узбекистан від 30.04.1998 № 598-I. URL: http://www.lex.uz/pages/GetAct.aspx?lact_id=149947. (дата звернення 02.02.20).

23 Жуков М.А. Актуальные проблемы регулирования земельных отношений / М.А. Жуков // Весник ОГУ. 2003., № 3. С. 115. 
the corruption in the sphere of the state regulation of land business; the stopping of the activity of the majority of subjects of property in the sphere of the usage of different categories of lands; the elimination of lands of the agricultural sphere and inputting them into the fund of the subdivision; the change of approved usage of lands; the difficulties of the transference from the system of the state regulation of the territorial intercourse when the one owner of the land is the state and the system of the state administration of territorial business while the pluralism of owners of the land; the irrational usage of lands that leads to the degradation of lands; the non-effective realization of laws in the sphere of the privatization of the agricultural lands; the absence of the effective system of activities as for the reflection of the negative activity of water and wind erosion of lands; the negative results of the land reform (the fall of the agricultural industry, the urbanization of the society, the intension of the inhabitants of the agricultural regions, the dependence from countries-exporters, etc.); the small percentage of the documental formation of the right of the usage of lands; the bureaucracy in the sphere of the formation of the right on the usage of lands for the leading of the farming industry; the spread orientation of the state administration of the territorial business etc.

We consider, that the priority level of the improvement of the state regulation of the territorial intercourse is the following: the creation of the one informational space for the accounting of lands on the state and the regional levels (for example, the one bank of resources about the territorial areas with the unified form of the information for all state agencies in the sphere of the regulation of territorial business and the ability of the available information in the real time); the improvement of the organizational structure of the interrelation between subjects of the state administration of land business; the improvement of the system of the division of land areas by means of the auction, free and beneficial subdivision of lands that are needed for the development of the social sphere of the state and the territorial authorities; the formation of the one viewpoint on the organization of the state administration of the territorial business and the usage of the land; the creation of the one for Ukraine scheme of the land management on the territory of the state.

\section{The Mechanism of the Legal Regulation of the Right of the Private Property on the Land in CIS}

The actuality of the investigation of the problem of the private property on lands in CIS is determined by the fact that in the USSR the private property on the land didn't exist and, accordingly, didn't exist the normative, the legal and the theoretical reasoning and the development. It should be mentioned that such a state of affairs in the legal regulation of the territorial intercourse at the 
soviet times till the present times has the negative influence on the development of the territorial legislation in CIS in this point.

While the land reform in some countries of CIS was withdrawn the monopoly of the state property of lands and were introduced different forms of the land property. The legislation of CIS states and identifies the variety of forms of the land property. It's influence and the systematization of forms lets to make the following conclusions: 1) the right of the private property of people on land areas is legally stated in 10 countries of CIS; 2) the right of the private property on lands of juridical persons is regulated legally in 8 countries of CIS; 3 ) the right of the common property on the land area is legally stated in 5 countries of CIS; 4) the right of the state property on lands is legally stated in all the countries of CIS; 5) the right of the municipal property on lands is legally stated in 6 countries of CIS; 6) the right of the property of foreigners and people without citizenship is legally stated in 6 countries of CIS; 7) the right of the property of the foreign countries on lands is stated legally in 4 countries of CIS.

There are forms of the property on lands in the legislation of CIS that is unique (the one) and is stated in the Territorial Code. For example, only in the Territorial Code of Russian Federation is pointed out the social property of the spouse on the land area, the common property of the farming industry on the land area and the property of the condominium. The right of the property of the international organizations on lands is determined in the territorial codex of Tajikistan Republic and according to which the one form of the property on the land is the property of the state on the land.

The conclusion: all forms of property on the land in CIS may be subdivided on two big groups: the private and the public property on the land. Different forms of the property influence on the territorial intercourse in the country.

In the modern theory of the territorial law the majority of scientists are against the existence of the private property on the land. For example, M.H. Vahaev proves the statement about "the private property on the land is considered to be the great freedom of the circulation of the land that is the great danger of the domination of the material values and interests while the usage of the land protection and safe of the cultural inheritance" ${ }^{24}$. The general position of the opponents of the private property on the territory is based on the following factors: the understanding of the right of the private property existing from the USSR; the irrational usage of the land by private juridical and physical personalities; the danger of the ecological safety;

${ }^{24}$ Вахаев М.Х. Дискуссионные вопросы частной собственности на землю в России / М.Х. Вахаев // Журнал российское право. 2006. № 5. С. 79-86. 
"the encroachment" on the state unity. Arguing with the position of these authors as for "the inadmissibility of the right on the private property", we consider that the right of the private property on the land is one of the main right in every democratic country. Thus, T.E. Chernavina states that for the outlining of the specification of the right of the private property on the land should be pointed out: the subject of the right of the property; the object of the right of the property; the contents of the right of the property; the measure of the eligible right of the property; guarantees of the right of the property ${ }^{25}$.

Summarizing approaches for the understanding of the right of the private property on the land we may state that the right of the private property on the territory is the form of the right of the property that presupposes the right of the usage, the owning, the administration of the territorial area or it's parts by private juridical and physical persons. The right of the private property on the land of citizens and juridical persons emerges while the privatization of the state and the municipal lands as a result of the inheritance, the giving, the buying-selling, the exchange or other agreements concerning lands as a result of the pointing out of the land area as an input to the statutory (share) capital of the juridical person ${ }^{26}$.

The criteria for the subdivision of forms of the private property is the subject of the right of the private property. According to this criterion is pointed out the right of the private property of physical persons and the right of the private property of juridical persons. It should me mentioned that in the Ukrainian territorial code the legislator spreads maximally the list of physical and juridical persons who can be subjects of the right of the private property. This tendency is observed in laws of other countries of CIS. That's why, the subjects of the right of the private property are: citizens of the country, foreigners, people without citizenship (according to the law); juridical persons, residents of the country (industries, cooperatives, social and religious organizations (unities), associations, unities), foreign and international organizations, united industries, social organizations, etc.

Investigating in details the subject structure of the right of the property on the land in Ukraine, should be mentioned the following: the subjects of property on the land of the industrial sphere are: the citizens of Ukraine; juridical persons and the created unities of citizens of Ukraine; the state agencies of the state power; the territorial unities of villages, towns and regions as agencies of the local administration. The subjects of the

25 Титова Н.Г. Рынок земли и его роль в повышении конкурентоспособности экономики / Н.Г. Титова // Экономические науки Вестник Нижегородского университета им. Н.И. Лобачевского, 2010. № 3 (2). С. 612-615.

26 Япаров Г.Х. Эффективное управление земельными ресурсами / Г.Х. Япаров // Ватандаш, 2015. № 7. С. 11-24. 
administration of lands belonging to the common property of territorial unities of a city are regional councils.

It should be mentioned that all forms of the property in CIS have the equal value and for foreigners or people without the citizenship is regulated "the national regime" (according to rights and duties the legislator equals them the citizens of the country ${ }^{27}$. In spite of "the national regime" for foreign physical and juridical persons the right of property on the land is strictly measured. For example, according to the Law of Ukraine foreigners can't be owners of lands of the agricultural sphere and can't be owners of parts of this category of lands.

In some countries of CIS is regulated that foreigners, juridical persons and people without citizenship can't own in private sphere land areas on the borders of the country (Ukraine, Kazakhstan Republic, Kirgizstan Republic, etc.)

The important fact in the investigation of the right of the private property on lands is the outlining of the object of the property. The objects of the property are individually measured land areas that as for the law have transferred to the subject and are in their property, usage and regulation.

According to Article 373 of the Civil Code of Ukraine the right of the private property on the land area is spread on the high (the soil) level in measures of this area, on water objects, forests, perennial planting, on superficial space, the high and the deep of which are necessary for the building of living, industrial and other buildings ${ }^{28}$. Accordingly, the owner of the land area has the right to use all that is on superficial space over the land area if the other point is not regulated in the law as for soils, the usage of the air space, and as for law rights of other persons. This point is investigated in details in the Territorial Code of Ukraine "the right of property on the land area is spread on space that is on and under the level of the land area in high and deep necessary for the building of houses, industrial buildings and other buildings" (Part 3, Article 79) ${ }^{29}$.

It should be mentioned that the territorial law in the majority of countries of CIS (Ukraine, Belorussia, Moldova and others) presupposes the ownership of any land areas in exclusion of some types of land areas that can't be the ownership of citizens or judicial persons (land areas eliminated from the circulation of land areas, restricted in the circulation). The amount and the variety of land areas that are in the private property is not restricted in exclusion of the regulated restrictions by the law. For example, according to the point of the Territorial Code of Kazakhstan Republic in the private

27 Фучко А. С. Конституционные основы права частной собственности на землю / А. С. Фучко // Вестник НГУ. Серия право, 2012. Т. 8. Вып. 2. С. 79-80.

${ }^{28}$ Цивільний кодекс України від 16.01.2003 № 435-IV URL: http://zakon3.rada.gov.ua/ laws/show/435-15/paran155\#n155 (дата звернення 02.02.20)

29 Земельний кодекс України від 25.10.2001 № 2768-III. URL: http://zakon3.rada.gov.ua/ 
property may be land areas for the agricultural or the farming activity, the private farming industry, the forestation, the planting, the individual household, and the given land areas for the building or land areas built by the industrial and non-industrial, housing, buildings (homes, houses) and the building complexes, including lands devoted to the service of buildings (homes, houses) according to their dedication. The right of the private property on the land has the absolute power of the owner that is contradictive to the passive duty of the non-regulated circle of persons who are abstained from the violation of such a right.

There are different ways to protect the right of property of the land: 1) ways to protect the right of property leaded on the protection of the violated right (vindication and negative claims); 2) ways to protect the right of property on the land leaded on the prevention of the violation of the right of property.

The peculiar place among ways to protect the right of property on the land is occupied by guarantees of the right of the private property on the land.

The analysis of laws in CIS lets conclude that the guarantees of the right of the private property may be of three kinds: On the international level. The main international normative and law act, that includes norms of the guarantee of the form of property, is the European Convention about the protection of humans' rights and main freedoms dated by 1950 (further in the Article - the Convention). In the Article 1 of the Convention is proved that "every physical and juridical person has the right on the respect of property. Anybody can't be refused from the property in spite of the interests of the society and on conditions according to the law and general principles of the international law"30. The Convention was ratified in such countries of CIS: Armenia, Azerbaijan, Moldova, Ukraine.

The conclusion: the ratification of the Convention by several countries of CIS gives the possibility of citizens of these countries to appeal to the European Union on Human Rights in Strasburg in case their right of the private property has not been defeated by the judicial system of the country of their citizenship.

On the constitutional level (for example, in the Point 1, the Article 13, of the Constitution of Ukraine is written "the land, it's subsoil, atmospheric air, water and other natural resources in the borders of Ukraine, natural resources of the continental borders, excluding the (sea) economic zone are the objects of the property of Ukrainian people. The power of land management is created by agencies of the state power and agencies of the local management

30 Протокол до Конвенції про захист прав людини і основоположних свобод від 20.03.1952. URL: http://zakon5.rada.gov.ua/laws/show/994_535 (дата звернення 03.02.20) 
according to the Constitution". In the Article 14 is stated the right of citizens and the unities to have the power to own lands "The right of property on the land is guaranteed. This right is given and realized by citizens, judicial persons and the state according to the law"31. The Constitution of Ukraine includes the strict constitutional guarantees of the right of the private property on the land, approves the general guarantees of the protection of rights and freedoms of a human and a citizen. Constitutional articles proclaim the right of citizens to own in the private property the land, are the legal constructions on the basis of which are created and realized norms and institutions of the territorial law $^{32}$. In this case the actual is the opposition by V.D. Zorkin about the role of the Constitutional Court of Ukraine. The scientist points out that "in the decisions the Constitutional Court has formed legal positions that reveal the constitutional sense of the right of property, the contents of the given right, borders of the realization, approved restrictions and guarantees of the judicial protection. This decision is of the precedent nature and is obligatory for all agencies, especially for the legislators and judges".

The conclusion: the guarantee of the right of property on the land is given to every legal owner of the land; the protection of the right of property while the direct and the indirect violation; the Constitution of Ukraine guarantees the protection of the right of property in spite of the form of property. The disadvantage of the constitutional regulation of the right of property is that in the constitutional norms is not included the direct instructions concerning the obligatory rational and effective usage of lands that are in the private property of physical and private judicial persons.

3. On the level of the territorial coded law and the industrial legislation (for example, in the Article 3 of the Territorial Code of Moldova is pointed out the statement that "lands of Moldova may be in the public and the private property",33).

In territorial coded law of the majority of countries of CIS the question of the private property is identified in separate chapters with the detailed explanation of categories of lands that could be objects of the private property according to the aim of their usage, the order of the buying and elimination etc.

Except the mentioned types of guarantees of the private property on the land D.A. Olnev divides guarantees of the private land property according to the mechanism of the protection on the following types: the judicial

31 Конституція України від 28.06.1996 № 254к/96-BP. URL: http://zakon2.rada.gov.ua/ (дата доступу 02.02.20)

${ }^{32}$ Харитонов Є.О. Цивільне право України : підручник / Харитонов Є.О., Старцев О.В. Вид. 2, перероб. і доп. К.: Істина, 2007. 816 с.

Земельний кодекс Республіки Молдова від 25.12.91 № 828-XII. URL: http://www.law-moldova.com/laws/. (дата доступу 02.02.20) 
guarantees of the right of the private property on the land (the right to appeal to a court on the protection of the right of the private property on the land); the administrative guarantee of the right of the private property on the land (the right on the individual or collective appeal to the state agencies and the local land managements with the protection of the right of the private property on the land); the guarantee of the self-protection of the right of the private property on the land (for example, according to the points of the Constitution of Ukraine "the state guarantees the protection of all rights of subjects of property and management, of the social leading of the economics. All subjects of the right of property are equal at the law").

The conclusion: the mentioned guarantees of the right of the private property on the land are marked by certain difficulties of the realization. It is pointed out the low level of the realization of judicial guarantees of the right of the private property on the land (for example, Ukraine occupies the leading place on the amount of contradicted appeals and on the amount of the final decisions concerning the violation of humans' rights).

Administrative guarantees of the right of the private property on the land is restricted by the giving to the state agencies and the local managing agencies different documents concerning the violation of humans' rights, the pre-trial solvation of the argument and the stopping of the criminal actions of the third persons. The self-protection of the private property on the land should correspond to such demands: to correspond to the way and the nature of the violation and may be used in case if the done (possible) violation is serious then refused.

The regulation of the intercourse of the private property on the land in CIS is based on the balance of interests of the private owner and the whole society. For example, in the Constitution of Ukraine is supported the need to regulate the restrictions, stating in the Article 41 the following statement about "the usage of property can't harm rights, freedoms and dignity of citizens, of the society, make harm to the ecological situation and natural quality of the land"34.

In the solvation of the question about the property on the land should be considered the national interests of the territorial unity and the state protection.

The conclusion: there aren't "the unrestricted" land managers in CIS, the right of property is restricted in the interests of the state and the society.

Including the above mentioned information and summarizing the statements of the territorial laws in CIS, we may outline the following peculiarities of the right of the private property on the land: 1) while the

34 Конституція України від 28.06.1996 № 254к/96-BP. URL: http://zakon2.rada.gov.ua/ (дата доступу 02.02.20) 
realization of the right of the private property on the land exists the need to carry ecological demands of the usage of lands, the need to protect rights and legal interests of other participants of the legal business; 2) the right of property on the land is restricted in socials aims because the land and other natural resources are the basis of life and activity of people living on the corresponding territory; 3 ) "the triad" of rights the owner of the land area carries in the measure of the existing law; 4) the land laws of CIS comprises the main list of ways of the protection of rights of land owners. The important point while the appeal to the court protection of the private property on the land is the right choice of the way of the protection of the violation of the right that corresponds to the level of the violation; 5) the owner has the right to alienate the land area to the property of other people, to give them the right of the property, the usage, the administration of the land area, give it to the mortgage, etc.; 6) the owning of the land is carried by the way of the stating the borders of the land area on the location; 7) the right of property on the land is regulated by the civil, the territorial, the administrative, the labor, the criminal, the taxing and the budget laws.

In spite of positive results of the territorial reforms in CIS may be outlined the following problems in the sphere of finance and development of the private property on the land: state agencies have approved the controversial legislative acts in this sphere; in all countries of CIS is pointed out the violation of rights of humans and the citizen on the natural resources; the high level of the corruption in the sphere of territorial intercourse; the low level of the inputs into the intercourse with the participation of private owners, etc.

We consider that problems in the sphere of the formation and the development of the private property on the land influence negatively on the destiny of the private property on the land in Ukraine and the effectiveness of the realization.

\section{The Market of Lands in CIS}

The becoming of the right of the private property on the land, the change of the administrative and the command regulation of territorial intercourse on the market regulation determine the formation and the development of the market of lands in CIS. The market of the land is the unseparated part of the economics of any developed country. The question of the legal regulation of the market of the land is actual for the majority of scientists who investigate it in the scientific researches. The land market is the part of the system of the territorial intercourse the regulators of which are the right of property (the owning, the usage, the administration), the possibility to transfer this right (the rent, the selling, the guarantee, etc.), the competitiveness (the free choice of a participator), the charged evaluation of the price free monitored on the land. 
The meaning of the land market in CIS is determined by the following factors: 1) the land market is the segment of the market economics that provides the increasing of the level of the competitiveness; 2) the land market is the way to realize business between subjects of the intercourse; 3) after the realization of territorial reforms in CIS emerged the majority of owners who don't have the relation to the agricultural sphere; 4) any land area may belong to any new owner and any land area has the fixed price.

The peculiarities of the land market: 1) the demand and the proposition on the land market is identified by the political system of the society, the geographical and the historical ways of the development of the country, the state of the infrastructure of the region and the level of the development; 2) the irrational price of the land as the object of nature the free natural gift; 3 ) the differentiation of land areas as for the category, the place of the location, the qualitative peculiarities and inputs into the increasing of the futility; 4) the restriction of the proposition of land resources according to the increase of the amount of private owners of land areas who consider not to sell their areas but to give them on rent for the input; 5) the formation of agreements on the land market demands the obligatory state registration and the complex, the charged juridical support; 6) the active activity of professional agents while the agreement on the land market; 7) the lack of land areas in towns; 8) the majority of land areas rarely change the owner; 9) the land market creates and supports the business of lands as the values, presupposes the maximal productive usage, creates mechanisms of the transference of the land to owners who can manage lands effectively.

Structurally, the land market in CIS is the subject of the market that comprises: buyers and sellers; renters and landlords; professional agents (agencies on operations with real estate, evaluators, notaries).

As for the formal criteria the land market in CIS is that is realized. The problems of the land market in CIS are the following:

1. The imperfection of the inventory evaluation and the accounting of lands: a) the choice transfer in the inventory evaluation of lands (for example, the inventory system of the separate countries of CIS was planned in the direction of the evaluation of the most perspective rating lands but not in the direction of the creation of the inventory plans; b) at the present moment agricultural land areas that are separated physically are not identified on the location and can't be objects of the inventory accounting and the registration; c) the inventory value of objects economically is not proved because the accounting is oriented on the technical and the juridical peculiarities of lands; d) the part of these lands can't be objects of the inventory accounting because these areas are not separated on levels of property and are the property of the state. 
2. The free land invasion.

3. The absence of the effective organizational and economical mechanism of the land management.

4. The decrease of the futility and the financing results of the activity of the agricultural industries, "the neglect" of the great areas of lands of the agricultural sphere.

5. The existence of the system of the legislative and the practical restrictions on the land market.

6. The general percentage of lands in the circulation from the general land fund in CIS is minimal.

7. The domination of business of land renting over the selling.

8. The formation of local (regional) markets of lands with the specific policy of prices and "the scattering" of prices around subjects of the market.

9. The land market proves the protection from the uncontrolled attitude to lands.

10. The price of the land area on the land market is formed without the connection to the usefulness.

The attention on the land market is given to the danger of the criminal offences in the sphere of the land circulation. To such a group belong the following crimes: the making the non-legal agreements as for lands by means of the falsification of documents that state the right of property on the land; the bribe of authorities with the aim of the non-legal owning of the land area; the violation to the agreement with the land area or the refuse of the realization; the violation to the elimination of the right of property on lands areas; the demand of a bribe for the owning of the land area; the registration of the non-legal lands agreements; the actions leaded on the bankrupting illegal to the buyers of industries with the aim to own the real estate (land areas), etc ${ }^{35}$.

The increasing of the open economics in CIS, the need to increase the competitiveness of subjects of the agricultural sphere demand nowadays the improvement of the land market on the basis of the further regulation of the business of the land management.

To our mind, ways to improve the land market in CIS and in Ukraine are: the need of the complex solvation of the question about the formation of the state land policy and the formation of the corresponding agency of the administration of the land policy; the formation of the legal basis of the parallel development of the land market in some countries of CIS, the

35 Москалькова Т.Н. Рынок земли и преступления в сфере земельного оборота/ Т.Н. Москалькова // Национальные интересы: приоритеты и безопасность. М.: ООО “Издательский дом ФИНАНСЫ и КРЕДИТ”, 2008. № 1 (22). С. 24-26. 
infrastructure of the land market of the agricultural sphere as a result of the transformation of the land to those who can use lands effectively and pay the high rent; the effective ways to oppose to the land "raiding" on the land market; the improvement of the criminal and the legal regulation of the protection of lands; the increasing of the legal protective practice in judicial and police agencies in such a sphere; the inventory accounting and the monitor of lands; the protection from the unproved transference of lands of the agricultural sphere to the category of less effective forms of usage; the optimization of taxes of the agricultural lands; the leading of the systematical and the institutional changes of the land market (the effective infrastructure of the land market is the unity of systems, services, industries and organizations that serve the market and provide the normal regime of the functioning; the complex of ways to the economical circulation and the effective administration of the land area as the economic object (the basic functions are: the choice of the best variant of the development of the object, the provision of the optimal scheme of the financing of the project, the retranslation of the international experience of the innovative technologies, the formation of the modern informational sphere; the creation of the territorial banks and exchange, etc.

We conclude that the state regulation of the territorial intercourse is the aimed activity of state agencies of the legal, the economical and the organizational nature that is leaded on the regulation of the business in the sphere of the rational usage of lands, their protection, the protection of owners.

The basic problems of the state regulation of the territorial business are the old land laws in the sphere of the state regulation of the land business; "the spread" system of the system of the state regulation in the sphere of land intercourse; the problem of the interrelation between state agencies of different levels and spheres of the influence on the land business; the dubbing of functions of state agencies; the absence of the united system of the accounting, the safe and the usage on the informational resources the information about land areas; the concentration of the great variety of land areas in separate great structures, etc.

The priority way to improve the stat regulation of the land intercourse is: the creation of the one informational space for the land accounting on the state and regional levels; the improvement of the organizational structure of the business between subjects of the state administration of the land business; the improvement of the system of the division of land areas; the formation of the one point on the organization of the state administration of land intercourse and the usage of lands; the creation of the one schema of the land management in the territory of the country. 


\section{CONCLUSIONS}

The territorial laws of the majority of countries in CIS (Ukraine, Belorussia, Moldova and others) presupposes the private property of land areas in exclusion of some land areas that can't be properties of citizens and the judicial persons (land areas, excluded from the circulation of land areas, restricted in the circulation). The amount and the price of land areas that are private properties are not restricted in the exclusion of cases when these restrictions are regulated by the law. The right of the private property on the land is of absolute nature, the right of the owner is opposed to the passive duty of the unregulated circle of persons to withdraw the violation of this law. Guarantees of the right of the private property are of three kinds: on the international level; on the constitutional level; on the level of the coded land law and the industrial law.

\section{SUMMARY}

Problems of the land market in CIS: the imperfection of the inventory evaluation and the accounting of lands; the violation invention of lands; the decreasing of the level of the futility; the damage of the financing of the agricultural industries; "the decreasing" of the great areas of the agricultural sphere; the existence of the system of the legal and the practical restrictions on the land market, etc.

Ways to improve the land market: the need of the complex solvation of the question as for the formation of the state policy and the formation of the corresponding agency; the formation of the legal basis of the parallel development of the land market of the infrastructure of the land market of the agricultural sphere as a result the agricultural land will be transmitted to those who can use it effectively and pay higher taxes; the effective ways to oppose land "raiders" on the land market, etc.

\section{REFERENCES}

1. The Constitution of Ukraine on June 28, 1996 No. 254k/96-VR. URL: http://zakon2.rada.gov.ua/

2. Constitution of the Kyrgyz Republic on 05/05/1993. URL: http://www.gov.kg/?page_id=263\&lang=en

3. Declaration on the principle of international law, that friendly friends and nations must agree on the status of the Organization before the Statute of the Organization of the National Assembly on 10.24.1970. URL: http://zakon4.rada.gov.ua/laws/show/995_569/card2\#Card

4. The Civil Code of Ukraine dated 16.01.2003 No. 435-IV. URL: http://zakon3.rada.gov.ua/laws/show/435-15/paran155\#n155

5. The Water Code of Ukraine dated 06.06.1995 No. 213/95-BP. URL: http://zakon3.rada.gov.ua/laws/show/213/95-\%D0\%B2\%D1\%80

6. The Code of Turkmenistan "On Land". URL: http://parahat.info/ law/kodeks-turkmenistana-o-zemle. 
7. The Land Code of the Republic of Moldova dated 25.12.91 No. 828-XII. URL: http://www.law-moldova.com/laws/.

8. The Land Code of the Republic of Azerbaijan on July 16, 1996 No. 695-IQ. URL: http://eco.gov.az/az/435-azerbaycan-respublikasinintorpaq-mecellesi.

9. The Land Code of the Republic of Uzbekistan dated 30.04.1998 No. 598-I. URL: http://www.lex.uz/pages/GetAct.aspx?lact_id=149947.

10. The Land Code of the Kyrgyz Republic on June 2, 1999, No. 46. URL: http://online.adviser.kg/Document/?doc_id=30241294.

11. The Land Code of the Republic of Virmeniya від 02.05.2001. No. 3P-185. URL: www.parliament.am/legislation.

12. The Land Code of Ukraine vid 25.10.2001 No. 2768-III. URL: http://zakon3.rada.gov.ua/.

13. The Land Code of the Republic of Kazakhstan dated June 20, 2003. No. 442-II. URL: http://online.zakon.kz/.

14. The Code of the Republic of Belarus on the land of June 23, 2008. No. 425-3 URL: http://www.etalonline.by/?type=text\&regnum=Hk0800425\# load_text_none

15. The Land Code of the Republic of Tajikistan dated 13.12.1996. URL: http://tabiat.narod.ru/LAWDB/1_10.html.

16. The Land Code of the Republic of Uzbekistan dated 30.04.1998 No. 598-I. URL: http://www.lex.uz/pages/GetAct.aspx?lact_id=149947.

17. The Law of Ukraine "On the State Land Cadastre" dated 07.07.2011 No. 3613-VI. URL: http://zakon5.rada.gov.ua/laws/show/3613-17

18. The Law of the Republic of Moldova "On the Normative Price and Procedure for the Sale of Land" No. 1308-XIII of 07.25.1997. URL: http://www.casa-ta.info/zakon/zakon4.php?lang=en.

19. Decree of the President of Ukraine "On the Strategy for Steel Development" Ukraine-2020 "dated 12.01.2015 No. 5/2015. URL: http://zakon2.rada.gov.ua/laws/show/5/2015

20. The Supreme Court of Ukraine resolves "On the practice of suing courts of land legislation in the process of reviewing civil law", dated April 16, 2004 No. 7 URL: http://zakon5.rada.gov.ua/laws/show/va007700-04

21. Borisov A.B. Big economic dictionary / A.B. Borisov. M.: Book world, 2003. $895 \mathrm{p}$.

22. Borodin S.S. Land law. General part: Lecture course / S.S. Borodin. $\mathrm{SPb}:$ SPbGUAP., $2000.215 \mathrm{~s}$.

23. Vakhaev M.Kh. Discussion questions of private ownership of land in Russia / M.Kh. Vakhaev // Journal of Russian Law. 2006. No. 5. P. 79-86.

24. Damdyn O. S. Land law: concept, subject and method of legal regulation / O. S. Damdyn // Young scientist. 2014. No 1. S. 211-213.

25. Damdyn O. S. State regulation of land relations / OS Damdyn // Young scientist. 2011. No 5. T. 1. S. 175-177. 
26.Zhukov M.A. Actual problems of regulation of land relations / M.A. Zhukov // Vesnik of OSU. 2003. No3. S. 112-116.

27. Zaitsev O.L. The right to inherit land in Ukraine: Abstract. dis. ... cand. legal Sciences: 12.00.03 / O.L. Zaitsev. National University of Internal Affairs - Kharkov, 2000. P. 9.

28. Kalinin N.I. Legal regulation of land relations in Russia / N.I. Kalinin - M.: Cooperation project "German-Russian Agrarian and Political Dialogue", 2011. 6 p.

29. Kolesnichenko VV. Principles of law of the European Union: the most theoretical understanding: abstract. dis. Cand. legal Sciences: 12.00.01 / Kolesnichenko Vadim Vasilovich; Odeska is a national legal academy. Odessa, $2010.22 \mathrm{p}$.

30. Lunyachenko A. V. The legal regime of agricultural land belonging to citizens by right of ownership: Dis. ... cand. legal Sciences: 12.00.06 / Lunyachenko Anatoly Vasilevich; Odessa National Law Academy. - O., 2002. $170 \mathrm{~s}$.

31. Makhortova O.A. The formation of the land market in the Russian Federation. Access Mode: http://www.rae.ru/forum2012/pdf/3113.pdf

32. Medentsov A.S. Cheat sheet on land law. Access mode: http://www.razlib.ru/shpargalki/shpargalka_po_zemelnomu_pravu/index.php.

33. Moldovan VV Jurisprudence: the first-hand post. 2nd view. / V.V. Moldovan, L.I. Chulinda. - K : Center for Educational Literature, $2010.184 \mathrm{~s}$.

34. Moskalkova T.N. Land market and crimes in the field of land turnover / T.N. Moskalkova // National interests: priorities and security. - M.: LLC "Publishing House FINANCE and CREDIT", 2008. - No. 1 (22). S. 24-26.

35. Muntyan V.L. Legal protection of soils of the Ukrainian RSR / V.L. Muntean. - K : Scientific Thought, 1965. S. 29-33.

36. ECHR report for 2016, including previous years - Official website of the European Court of Human Rights. Access Mode: https://roseurosud.org/ espch/statistika-espch-1959-2016.

37. Official website of the State Property Committee of the Republic of Belarus URL: http://www.gki.gov.by/ru/activity_branches-land/.

38. The official website of the Federal Service for State Registration, Cadastre and Cartography. URL: https://rosreestr.ru/.

39. Polyakov II Theory of understanding the essence of the object of legal relations / II. Polyakov // Teaching notes of the Taurida National University named after V.I. Vernadsky: Series "Legal Sciences". - Tom. 19 (58), No. 2. - 2006. S. 113-117.

40. Protsenko E.V. The essence and legal content of the right of private ownership of land / E.V. Protsenko // Legal Thought. 2011. No 2 (64). S. 101-107. 
41. Direct and indirect state regulation of the economy. Access regime: http://econtool.com/gosudarstvennoe-regulirovanie-ekonomiki.html.

42. Stechenko D.M. State regulation of the economy: Nav. pos_b. 3-th view., Vypr. K., 2006.262 s.

43. Titova N.G. Land market and its role in improving the competitiveness of the economy / N.G. Titova // Economic sciences Bulletin of the Nizhny Novgorod University. N.I. Lobachevsky, 2010- No. 3 (2). S. 612-615.

44. Fuchko A.S. The constitutional basis of the right of private ownership of land / A.S. Fuchko // Bulletin of NSU. Series law, 2012. V. 8. Vol. 2. P. 76-82.

45. Kharitonov E.O. Civil law of Ukraine: fiduciary / Kharitonov E.O., Startsev O.B. - View. 2, reoff. i additional K : Istina, $2007.816 \mathrm{s.}$

46. Shvaika L.A. State regulation of the economy: Textbook / L.A. Shayka. K : Knowledge, 2006.435 s.

47. Yaparov G.Kh. Effective land management / G.Kh. Yaparov // Vatandash, 2015., No. 7. s.

Information about the authors: Stratonov V. M.,

Doctor of Science (Law), Professor, Professor at the Department of the Industrial Law, Kherson State University 27, Universitetska str., Kherson, 73000, Ukraine

ORCID: 0000-0002-7548-0630

Gavlovskaya A. O., $\mathrm{PhD}$ (Law), Professor, Assistant Professor at the Department of the Industrial Law, Kherson State University 27, Universitetska str., Kherson, 73000, Ukraine ORCID: 0000-0002-7973-7560

Pavlish P. V., $\mathrm{PhD}$ (Law), Deputy of the Verkhovna Rada of Ukraine 5, Hrushevskoho str., Kyiv, 01008, Ukraine ORCID: 0000-0001-5206-9307 


\section{A NEED OF ENVIRONMENTAL LEGAL FRAMEWORK EVOLUTION}

Sydor V. D.

\section{INTRODUCTION}

The importance of research on overcoming the gaps and solving conflicts in environmental legislation on the state lawmaking processes, identify their watershed character, qualitatively new state of society and the new challenges faced by national environmental legislation and law. Nowadays the environmental laws and legislation cannot avoid gaps in the legal regulation of environmental relations.

Gaps in environmental law and legislation affecting the implementation of subjective rights to natural objects, the performance of legal duties to protect the natural objects, but also make it difficult or even impossible to protect rights and interests in the emergence of new environmental relations. Lack of legal regulations only required amount of environmental relations is an objective factor that predetermined lag environmental legislation of Ukraine from changing environmental relations. Therefore, the presence of gaps in the environmental legislation requires solving the problem of their elimination. Gaps in environmental law should be considered in the absence of a specific provision legal act.

Gaps in environmental law and legislation affecting the efficiency of the legal regulation of environmental relations. Gaps, which is one of the legal defects of the environmental law, will have a significant negative impact on the regulation of environmental relations. To detect the presence of gaps environmental regulation to establish that certain environmental relations within the scope of legal regulation. In addition to detecting the absence or incompleteness of the legal regulation of environmental relations, to prove the need for their legal support.

\section{Directions for Improving Environmental Legislation by Eliminating Gaps and Collisions}

Gaps in environmental law is undesirable as it causes many negative consequences, preventing a stable full protection of rights. Imprecision in the language, incorrect or incomplete use of tools and techniques of legal technology, gaps in the regulation of individual relationships - it causes difficulty in the implementation of legal norms ${ }^{1}$.

\footnotetext{
${ }^{1}$ Алексеев С. С. Общая теория права: в 2-х т. М. : Юрид. лит., 1981. Т. 1. С. 93.
} 
Gaps in current environmental law and legislation is a negative phenomenon that destabilizes public environmental relations. The destructive potential of gaps in environmental legislation is particularly dangerous during the land reform and radical transformation of legal institutions. In modern terms of legislation, a lot of the problems of subjective and objective nature caused by such violations during legislative work:

(a) the discrepancy of certain provisions of a number of regulations of the fundamental principles of the Constitution of Ukraine, the practice of making changes to existing laws, sub-legal acts, which complicates the process of law;

(b) parallel existence of regulations that are issued at different times by different government agencies and content contradict each other, lack the necessary consistency and the relationship between regulations, which complicates the process of their implementation;

(c) imperfection content of new regulations, unfounded and inappropriate use of complex terminology, borrowing foreign language that makes legal act incomprehensible and inaccessible to perception.

Gaps is a lack of environmental law system of legal regulations regarding the circumstances that lie in the field of regulation and require legal impact. The gaps in the legal regulation of environmental relations - a state of legal uncertainty arising from the total or partial absence of objectively necessary link in the legal impact of environmental relations. The presence of gaps in the environmental law and legislation is an objective phenomenon, which can not be avoided even by the most perfect and detailed legal regulation.

The reasons for the gaps in environmental law are:

- the inability legislator to represent normative prescriptions in the variety of life situations that require legal regulation (primary gap);

- legislator inability to predict the emergence of new situations as a result of continuous development of social relations, to carry them on some legislative acts (secondary gap);

- technical errors legislator made in the development of laws and methods of use of legal technology.

Gaps in environmental law - is a situation of legal irregularity existing environmental relations that require legal regulation and protection, and the environmental laws completely or partially missing the required legal standard.

Types of gaps:

1) full gap - in environmental legislation necessary for regulating environmental relations norms;

2) partial gap - the presence of the required rate, but it could not use.

The presence of gaps in the environmental legislation is a factor that reduces the effectiveness of the legislation in the field of regulation of 
environmental relations. The presence of gaps can be combined with the efficiency of the functioning of the legal regulation of environmental relations if the current legislation provides effective means to overcome gaps in the law enforcement activities. Gaps in environmental law is a negative phenomenon that destabilizes environmental relations.

Flaws and contradictory environmental laws adversely affecting the work of all branches of government, greatly complicates the tasks facing them significantly reduces the ability of legislation to effectively regulate social relationships weaken the regime legitimacy affects not the level of law and order in the country hinders the implementation of human rights and freedoms and citizen. Installing the gaps in the legal regulation of environmental relations and their management are two components of a single thought process based on the same logical operations, which in turn are related to the ways interpretation of environmental laws. Filling gaps means filling passage in the law, overcoming the gaps is meant to shift through the gap without filling its content.

Therefore, the role means to fill the gaps, can play only a source of law. Bridging gaps in law by applying the law for Ukraine is not traditional, so the gaps are eliminated through the issuance of new legal act or amending the previous Act, or cancels. Incomplete regulation of environmental relations opens the way for the creative capabilities of law enforcement in the selection of its activities.

However, the legal uncertainty in resolving environmental issues to deal with than their discretion so that obtained from the decision was fair, did not violate the rule of law. Environmental legislation in general is characterized by lack of integrity for the effective regulation of environmental relations, the presence of internal contradictions, gaps and ambiguous provisions, lack of standards that promote the development of market mechanisms for environmental use and protection, availability of interbranch conflict, lack of an integrated approach to the legal regulation of environmental relations. Environmental laws based on outdated approaches may even promote the deepening crisis in environmental relations.

Mechanism to overcome gaps in environmental law is a set of interrelated and interacting regulatory and organizational institutions by which defined areas of filling and close the gaps in the environmental law, the increase of the efficiency of the legal regulation of environmental relations.

Bridging gaps in environmental legislation involves removing gaps in the legal regulation of environmental relations through the activities of the Verkhovna Rada of Ukraine aimed at the ultimate elimination of legal irregularity environmental relations, normative and casual filling in gaps in environmental law. Normative fill gaps by using interpretation of authorities 
having jurisdiction in the interpretation of delegated legislation. Casual filling gaps implemented by officials of state and local authorities in the field of natural objects use and protection in the implementation of specific law enforcement activities.

Gaps in current environmental legislation is one of the causes of the crisis of law in environmental relations. Complex problem of collisions of environmental legislation. Stability regulation of environmental relations largely depends on the quality of the system of environmental laws and rights, which is currently unbalanced and has internal contradictions.

One of the main reasons for the low efficiency of the regulatory capacity of environmental law is the existence of collisions. Contradictions of the key issues of legal regulation of environmental relations in Ukraine reduce the effectiveness of the mechanism of regulation. Requires a clear mechanism to prevent and resolve to overcome and eliminate the phenomenon of collisions that prevents the development of environmental laws.

The rapid development of environmental legislation creates controversy related to the difference in the time the legislation passed, and the fact that some laws are not consistent with each other.

Collisions in environmental law and legislation in the broadest sense - is legal controversies that can go into open legal conflicts, and expressed not only in legal norms, but also in the interests of the opposing environmental relationships. Collisions in environmental law and legislation in the narrow sense - a contradiction between individual environmental legal provisions aimed at regulating the same environmental relations.

Competing in the legal regulation of environmental relations - a difference or discrepancy, the discrepancy between the requirements of regulations governing the same social relations associated with the use, protection and restoration of natural objects and can not be used simultaneously.

Collisions of environmental law is objective phenomenon. It is the content differences between two or more legal acts adopted with one and the same issue. Conflicts prevent proper application of the law and thus reduce its effectiveness. Reasons of collisions related to the quality of environmental laws and rights of insufficient systemic nature of their development. Therefore, the development of environmental laws and legislation is impossible without improving the efficiency of the legal impact of environmental relations.

Collisions in environmental legislation determined by the objective and subjective factors of social development. This formal contradiction between the rules of law aimed at regulating the same relations in the rational and purposeful use, integrated playback and effective protection of natural objects, creating difficulties in enforcement activity. 
The main factors that cause collisions in environmental legislation are objective factors (statics of environmental law and dynamics of environmental relations) and subjective factors (lack Concept of environmental law, poor training legislator, violations of legal technique, inconsistent legislative activity in the legal regulation of environmental relations, improper ordering of environmental law).

Collisions in environmental law is a conflict or discrepancy between the requirements of regulations governing the same legal relationship, and are in the process of their application by the competent authorities; collisions is the kind of contradiction in the legislation of Ukraine, resulting from the manifestation of various complex, objective and subjective reasons, economic, political, social, legal.

In the area of regulation arise collisions of two kinds: material - between public environmental relations; formal - between legal regulations. Legal collisions - is due to objective and subjective factors of social development formal contradiction (the difference) between the rule of law (complex legal rules), between the rule of law and interpretation of acts aimed at regulating the same social relations that creates difficulties in law enforcement ${ }^{2}$.

Typical shortcomings environmental law is a contradiction between the newly admitted and current regulations, by the laws and regulations. Sometimes there is a discrepancy regulations of the same legal act, distortions in them fundamental, basic principles and the principles of environmental law. Contradictory, duplication, gaps in the legal regulation of environmental relations and the lack of effective mechanisms for the implementation of the environmental law have become commonplace in lawmaking practice.

All this creates problems with performance acts environmental laws, complicating law enforcement practices. Modern environmental law does not fully satisfy the growing needs of the implementation of constitutional rights and freedoms of man and citizen, the effective implementation of the tasks and functions of the democratic, social, rule of law, does not meet the level of maturity of civil society and perspectives of its development. In order to improve the current situation and improve the efficiency of environmental legislation, the main effort in our opinion, lawmakers should focus on the development of the concept of environmental legislation of Ukraine.

Legal doctrine has created a theoretical framework for the prevention, elimination and resolution of legal collisions. The main ways of preventing collisions is fixing in law collision rules, the abolition of (changes) of one or

2 Майстренко О. В. Теоретико-правові аспекти колізій у законодавстві України: автореф. дис. на здобуття наук. ступеня канд. юрид. наук: спец. 12.00.01; Нац. ун-т внутр. справ. Х., 2008. С. 9. 
all of the collision rules are in conflict. One of the main ways of dealing with collisions is systematization of environmental legislation. Negative collisions of environmental legislation giving rise to the alternative choice of the most convenient norm in the process of solving a particular case, thus creating a real option of ignoring the rule of law and legality in the implementation of the law, distort the legal culture and generate legal nihilism. Collisions offer opportunities for the manifestation of subjectivity persons in the application of legal norms.

The basic rules resolve collisions in the legal regulation of relations are:

1) the principle of resolving collisions law by legal force of acts;

2) the principle of resolving collisions by legal rule "later act";

3) the principle of resolving collisions law by the rule of "special rules"3.

Legal validity of a legal act affects a meaningful reflection of its impact on social relations to overcome the significant shortcomings of current legislation, identifying and finding ways to resolve the conflicts between the old and new rules regulations. To overcome the collision of environmental legislation can be achieved by streamlining the system of environmental law and maintain its equilibrium by setting strict grading regulations and its compliance in the rulemaking.

Collisions can be resolved by maintaining the legal system in the state of functional equilibrium. It is important to eliminate the double regulation of environmental relations. It is unacceptable placing similar regulations in various fields of law - a direct and inevitable consequence of this is the collision. Eliminating duplication and preventing it should be guided by the principle: the regulation of environmental relations should be as general as possible. With proper construction of the legislation (as in "special" legislation will be placed really special orders, and "general" - general) needs a "collision rules" that specify the relationships between the different branches of legislations, will not - instead them will apply the general principle of conflict "special rule". If the legislation is built correctly, and "general" law contains special rules "collision rule" only harm.

The main preventive measures against collisions in environmental law and legislation:

- forecasting and planning of legislative activity, improve technique of legislation, legal examination regulations;

- systematization of legislation.

Mechanism of overcome environmental laws collisions is a set of legal tools, techniques and procedures aimed at preventing new address and

\footnotetext{
${ }^{3}$ Мірошниченко А. М. Колізії в правовому регулюванні земельних відносин в Україні: монографія.; Ін-т законодавства Верховної Ради України. К.: Правова єдність, 2009. С. 62.
} 
overcome existing conflicts in environmental law. The structure of the mechanism to overcome environmental laws collisions includes the following components: a rule-making, collision rules and systematization of environmental legislation.

The dynamics of environmental legislation of Ukraine is characterized by extremely complex and contradictory processes. As a result of active legislative activities significantly increased the number and at the same time contradictory legal regulations. Environmental legislation has large amount, a lot of collisions, often legal rules governing the same environmental relations are duplicated in different regulations. Quality environmental law is defined as a set of essential features of the law that reflect its merits and determine the ability and opportunity to environmental legislation to meet the needs and interests of society and citizens in natural objects use and protection. Environmental legislation has many parameters, while in different environmental relations appear specific to each case as environmental laws, which vary with the development of environmental relations.

Quality parameters of environmental legislation can be divided into three groups:

1) features that reflect the essence of environmental law as a legal phenomenon (rule, normativity, formality);

2) features that reflect the degree of perfection of environmental law (his correspondence to the real environmental issues, resource support, compliance with the Constitution);

3) features that reflect the results of the environmental laws (reality, stability, dynamics).

The tension between legal prescriptions today permeate the entire system of environmental laws. In its structure now clearly seen some negative trends - needless multiplicity of acts in the regulation of environmental relations alone while their failure in the regulation of other environmental relations, the imbalance of the legislative process, numerous violations of procedures for the adoption of laws and rules of legislative technique ${ }^{4}$.

Improving environmental laws - is the work of the competent authorities of the state to maintain the quality of legislation (the quality of its content and form) according to the needs of environmental relations, which aims to ensure effective regulation.

Based on these criteria to form the improvement of environmental law and legislation include:

4 Сидор В. Д. Земельне законодавство України: сучасний стан та перспективи розвитку: монографія. К.: Вид-во “Юридична думка", 2011. С. 138. 
- discussion of draft regulations, approval of draft legal acts, examination of bills signed by the President,

- state registration regulations relevant legal authorities amendment and revision of existing regulations,

- elimination of illegal applicable regulations,

- the official regulatory interpretation of existing regulations, termination is unconstitutional and illegal regulations judicial decisions ordering regulations.

Enhancing the role of the legal regulation of environmental relations requires streamlining of legislation that provides for simultaneous updates of laws through the adoption of new and improvement of existing regulations.

The specific shortcomings environmental legislation include:

- uncertainty priorities in making laws, instability and internal contradictions of laws and their individual rules;

-imbalance in the ratio of the laws, regulations and administrative regulations,

- lack of scientific validity of the legislation, and their declarative addressless others.

Given the large number of regulations environmental laws, high level of collisions of prescriptions, gaps and other defects environmental regulation, the need for its systematic long overdue.

Conducting systematic aimed at finding and solving conflicts, identify ineffective rules and replace them with more efficient legal requirements, clearing accumulated legal material by eliminating duplication of regulation and ineffective regulations, identify gaps in the legal regulation of environmental relations and their filling, ordering rules of environmental law and enforcement them in a system to improve the efficiency of the legal regulation of environmental relations in Ukraine.

To ensure consistency of the existing array of environmental legislation of Ukraine in the legislative work to be solving interrelated objectives:

- improvind the existing environmental laws,

- the elimination of gaps in the legal regulation of environmental relations,

- overcoming collisions of environmental legislation,

- develop recommendations for further areas of environmental legislation providing for solving problems of lawmaking.

The most common shortcomings environmental legislation are:

- inconsistency environmental issues, interests and needs of people;

- the contradiction between legal norms;

- low level of systematization;

- lack of sharpness and clarity of the legal requirements and regulations, which leads to a violation of law in the field of environment. 


\section{The Ratio of Public and Private Components in Environmental Legislation}

Science of environmental law is going through a difficult period, associated with changes in the principle value of public and private interest in the regulation of environmental relations. In present conditions of Ukraine's legal system sharpened debate on the division of law to the appropriate field, distinguishing public law and private-law institutions. One of the effective steps of improvement of legislation is the optimization of private and public law principles in establishing the mechanism of regulation. The Constitution of Ukraine created the necessary conditions for the formation and establishment of a new environmental law considering the transition to a market economy and secures new conceptual basis for regulating environmental relations.

Public law type of regulation is characterized by the fact that in the areas of public law in the first place are obligations of participants of public relations in its various forms (prohibitions, regulations, etc.). By the nature of norms and orientation influence public law is mainly imperative, and the main result of his influence should be strict implementation of the participants of public relations requirements contained in the law.

Public legal principles of environmental legislation of Ukraine is objectively due to the principles that determine the need, purpose, features, content and the use of public law in the mechanism of regulation ${ }^{5}$. The object of public legal restrictions may be any fixed in-law environmental rights. The ways of the law on public legal restrictions of environmental rights is a normative set of boundaries and limitations purposes, restraining orders, list of facilities and the range of subjects related environmental rights.

Lack of necessary scientific basis transformation property in Ukraine, imperfections and dynamics of the law in this area is not conducive to effective legal regulation of environmental relations. In today's special urgency and severity is the question of public law principles of environmental law, public ownership, its subjects and objects. From the solution of this question depends largely on the integrity of the state, effective protection and use of natural resources, the interests of the population of Ukraine and local communities. The intervention of public law principles in the sphere of property aimed at protecting the interests of the whole society.

That feature of the environmental law is that it is a sphere interaction of private and public interests, and therefore the regulation of environmental

5 Костицький В. Міжнародно-правовий етичний імператив як основа теоретикометодологічного забезпечення розвитку екологічного права. Право Украӥни. 2011. № 2. C. 30 . 
relations is done using public law and private law means. Urgent task in conducting legal policy is to ensure optimal ratio of public law and private law principles in the environmental law in establishing a stable order in the country.

Soviet jurisprudence did not recognize the separation of the right to private and public. The main motive of the denial of the division was that the basis of private law, private property, and if it is missing, the missing, and private law. Today recognition of private ownership on natural resources causes the development of private foundations in environmental law.

Private regulation of environmental relations is characterized by the following principles as the recognition and protection of private ownership, independence and autonomy of the subjects of environmental relations, equality of subjects ownership. It is in these aspects of private regulation of environmental relations intervene public legal means, resulting in a restriction of the right of private ownership, a restriction on freedom of transactions. Penetration of private regulation in environmental relations includes not only the creation of new institutions, but also rethinking those who are traditional environmental rights. Statewide legislation is an independent branch of the law of Ukraine is a system of regulations that govern environmental relations. The foundation of the formation of modern environmental law were laid in the last decade of the last century.

Modern environmental law considers the natural objects together: as a natural resource and as property. Environmental legislation, combining private legal and public legal methods of influence, designed and capable of ensuring the rational use and protection of natural resources.

There is a need to improve the mechanism of incorporation of public interest in private law rules governing environmental relations, and the problem is also the so-called inverse penetration of public law principles in modern private law. The interpenetration of public law and private law principles creates the need to develop the modern theory of environmental law in the direction of seeking their optimal value and interaction.

Environmental legislation in its substantive sense is a set of rules aimed at protecting public and private environmental interests. Environmental interests considered constructing category as a decisive factor in the impact and meaning of the environmental law, the driving force of their motive and behavior of environmental relations. External criteria publicity environmental interests is standard form of expression. It is important to study the problem of establishing balance, finding a universal correlation between the public and of private interests. There is a need to unite in a fundamentally new scientific issue series of general and sectoral aspects of security and protection of environmental rights. 
This is due, on the one hand, dynamic environmental conditions of formation and use of environmental legislation, sharpening needs of economic development and environmental interests of society, increased exploitation of natural resources in current market conditions, on the other hand - the practical needs in the legislative process and enforcement activity theoretical concepts justifying the ways of legal harmonization of various environmental interests. Criteria rights division between public and private but well-known criteria subject and method of regulation may serve interest. Interest is the values, target and meaningful basis impetus to normative mediation and development of any subjective rights. Value of public law and private law interests in the legal regulation of environmental relations are legally legal indicator of the quality of the political regime in the relevant historical and legal point of society.

A special way to regulate the relations of public interests in environmental law formed mainly of prohibitions and regulations, public-legal restrictions on economic activities, subject composition owners and users, functional and regional use restrictions. Legal restrictions can be seen in the narrow and broad sense: as either a synthetic method of legal regulation, which is formed mainly prohibitions and obligations as a generic term that includes the proper restrictions, encumbrances and different requirements imposed on the subjects of environmental relationships. Existing in environmental law set limits is an important tool for regulating environmental relations. Purpose of legal restrictions is to ensure public environmental interests.

The source of public legal restrictions is a constitutional provision. Since the constitutional provisions of Art. 13 on the property of the Ukrainian people to all natural resources within the territory of Ukraine follows the principle of equal access to natural objects. Equality and fairness in environmental relations based on formal, legal equality. The principle of legal equality involves the introduction state the conditions under which any entity of environmental rights may be subject of environmental relations. Restriction of economic activities in order to ensure public environmental interests should be imposed by the current environmental legislation under the Constitution of Ukraine, based on guaranteed constitutional right of every citizen. The constitutional and legal position justification environmental legal restrictions possible on the basis of second part of Article 13 of the Constitution of Ukraine, which secures that the property should not be used to the detriment of the person and society ${ }^{6}$. An important task is to determine the extent of lawmaking admissibility limit private interests to protect the environmental rights of citizens and public environmental interests.

${ }^{6}$ Конституція України, прийнята на п'ятій сесії Верховної Ради України 28 червня 1996 року. URL: https://zakon.rada.gov.ua/laws/show/ 
An important way to ensure the public interest is the regulation of free access of all citizens to the natural resources to ensure freedom of movement and enjoyment of aesthetic, recreational, recreational needs.

Unity and cooperation of public law and private law principles based on the use of general categories and concepts developed in the theory of law, such as the rule of law, prohibitions, permissions, responsibilities, etc. Private and public law serve as two main areas of regulation, each of which governs the appropriate field of public relations.

The object of science is the study of environmental law legal regulation of environmental relations, including the problem of interaction between public law and private law principles of their regulation. Studies of various legal phenomena only from the standpoint of public or private law do not give full and comprehensive understanding of their legal nature, do not allow to achieve the goal of complex study of complex processes and phenomena suggest effective ways of improving environmental legislation.

Private and public law in all developed legal orders continue to exist as two separate, independent branches regulation as two different types of legal impact on social relations. However, it should recognize and take into account that the private and public sector is always communicate with each other, resulting in some emerging areas of law in which the elements of public law regulation penetrate the private right and vice versa.

Identifying elements of public law and private law regulating the environmental law and determining their characteristics, should proceed from the fact that the main criterion for separation of private and public law, is the difference in techniques and methods of influence on environmental relations. To correct their differentiation is also necessary to consider the sequence of factors that affect the formation of the environmental law, according to which the interests of the subjects of environmental relations define the content and the specific properties of these relationships, in turn, determine the nature of legislative requirements.

Environmental legislation is not a mechanical combination rules breaking equality and norms based on relations of power and subordination, actually environmental legislation is built on a combination of such methods.

This relationship is present in some of the legal norms, increasing the level of legal institutions and becomes a fundamental level of environmental law in general. Try to break this relationship means to eliminate environmental law as a branch. Complex (private law and public law) the nature of legalization of environmental relations finds its manifestation terminology in the current legislation. Based on the basic directions of state environmental policy and based on the adoption of specific and interrelated environmental law, formed a set of legal mechanisms impact on certain types of environmental relations. The rules of 
legal mechanisms have both public law and private law and are primarily aimed at ensuring a balance private and public interests in the community.

The value of environmental laws as an independent field lies in the possibility of its use as a tool of the complex legal impact on environmental relations in the state.

The widespread use of public-legal means of regulating environmental relations can not be seen as government interference in private law relations. This fact underlines the need to combine these tools, without which it can not effectively use the environmental legislation. Value the use of private and public law principles in the regulation of environmental relations is not permanent. It depends on the specific conditions of the economy.

Interaction and mutual influence of public law and private law principles specific to regulation of environmental relations. One can not ignore that the dramatic changes of private law regulating environmental relations can not affect the state of public regulation and vice versa. Therefore, changes in the field of private regulation must be accompanied by an analysis of the consequences of such changes in public environmental relations. The same can be said about the changes in the regulation of public environmental management.

The main task of law-making can be formulated as creating, updating and improvement of environmental legislation. Activation of lawmaking that observed in recent years, along with its positive moments, bare and negative consequences. Logical contradictions, gaps and overlaps, lack of mechanisms for the implementation of the environmental law have become common place in lawmaking practice in Ukraine. Basic flaws in lawmaking are causing problems with the implementation of regulations, thereby complicating law enforcement practices.

Today there is a clear need to improve law-making practices, improving the quality of legislation being developed. The need for developing a concept of environmental legislation of Ukraine due primarily needs to improve it, the task of strengthening the rule of law, increasing the need for proper, efficient use of environmental law, need a balance between the stability of environmental laws and the dynamics of public environmental law.

The most common shortcomings of environmental legislation is discrepancy public environmental issues, interests and needs of people, conflicts between legal norms, low level of systematization, lack of sharpness and clarity of the laws, which leads to a violation of law.

Major issues that need solutions are:

1) inadequate legal and organizational support for the acquisition and termination of environmental rights;

2) the settlement of all complex property relations;

3) inadequate measures legal protection of natural objects; 
4) an effective system of environmental management, improvement of the legal framework for environmental management and environmental monitoring;

5) inadequate implementation mechanism and protection of citizens' environmental rights;

6) facilitation of voluntary abandonment of ownership;

7) preventing and overcoming various strains of market pricing mechanism and price parameters of natural resources;

8) legal registration of land and mortgage lending.

The purpose of environmental law is to improve Ukraine on the following basic principles:

- legislative strengthening the legal regime of natural resources;

- balance of the state, public and private interests;

- transparency of state and local government;

- harmonization of domestic environmental legislation with international and European law.

Systematic environmental legislation is the most important factor in organizing legislative activity to achieve the challenges facing the state and society in the field of environmental relations. It provides a uniform understanding and application of the law throughout the state, the treatment requirements of environmental legislation to any and all subjects of environmental relations.

To ensure consistency of environmental legislation is necessary to satisfy a number of conditions:

- the scientific validity of acts of environmental laws;

- a high level of legal awareness and legal culture of society;

- the creation of science-based system of monitoring the effectiveness of environmental laws;

- a priority of international and European law in the national legal system.

Modern environmental law acts are characterized by significant shortcomings, which are the norms that are not governing the specific environmental legislation, but have a declarative character, full of contradictions, unclear wording, stylistic shortcomings and other inaccuracies. Large-scale land and agrarian reforms do not reach their goals through the individual and disparate changes in the environmental legislation. The process of the development of the environmental legislation of Ukraine in recent years has led to the emergence of many non-traditional problems in legal technology. Legal technology category stands out for its complexity, versatility and multidimensional nature. It is characterized by a number of key features, which include the following:

- legal machinery, which is a set of tools and techniques intangible, technical, legal technique shown in the rules (norms) by which she used; 
- legal machinery materializes at legal (normative) acts.

Once the tools and techniques of legal technology really embodied in acts, they become the property of the legislation. The culture of the lawmaking directly provides a coherent statement of the content of the law.

Violation of the law of logic, the inaccuracy of its concepts and formulations used terms uncertainty lead to changes and additions, many requests of different interpretations and explanations, distorting the law and its application. Rules of the legal technique is quite complex in its normative nature and are set by the state requirements about tools and techniques of legal technique for the most perfect preparation and organization of the state laws. To the substantive and formal legal rules legal technology include rules for choosing the proper form of the legal act to regulate certain land relations, preparation of the bill concept, defining the boundaries of the law, the rules of the legal definitions formulation, which create a regulatory framework of the draft.

Among the most important legislative issues at the present stage are:

1) lack of constitutional control at the lawmaking stage;

2) errors forming a text of a statute - transferring of the developed legislative decision to the legal structures and formulas;

3) the power of the organization and expert support of the legislative process;

4) the absence of complete, accurate and practical model of the quality law (norm of law);

5) the absence of logic and consistency in changing of the legislation;

6) design errors in the drafting of the legislative solutions and more.

In this regard, the laws are overwhelmed by the blanket rules, which contain obscure items, adopt many norm legislative acts that contradict the Constitution of Ukraine. The legal technology of the environmental law system of Ukraine is scientifically sound and contains practically proven tools, techniques, methods used in the process of the environmental legislation adaption.

The legal technology of the environmental laws is a special legal phenomenon, which should not only be limited to the practical activity of designing draft acts of the environmental legislation.

Based on theoretical and legal analysis the following types of modern legal techniques of environmental law are identified:

- rule-making - a set of rules, methods, tools and techniques used by the subjects of the legislative process when creating norm legislative acts;

- enforcement - the technique of the formulation and adaption of the preventive acts by the correspondent organizations;

- interpretational - the technique of the formulation of the act, which explains the norm of the law and identifies the precise definition of it; 
- systematization - the technique of the organizing of the norm legislative acts in the organized system.

The important role in the improving of the legal technique plays the Legislative examination. In Ukraine Legislative examination is performed by the Chief Scientific Expert Department of the Verkhovna Rada. Its main task is to conduct a scientific examination of bills conceptual levels; the legal, economic, social appropriateness of the adaption of the law; and its conformity with the Constitution and international treaties, its correspondence to the current level of scientific knowledge, principles of the state policy; forecasting the consequences of their adaption. The problem of the environmental laws is that the drafting of the laws, identification of the future trends of the development of the environmental legislation and participatation of the specialists in their resolution is sporadic.

\section{CONCLUSIONS}

The level of the environmental legislation perfection depends on the legislative technique, the efficiency of its action, deep understanding and appropriate application, and also on the systematization of the environmental legislation. The maximum use of the implementation tools of the legal technique in the preparation of the draft laws is a necessary consequence of the environmental lawmaking. Failure to comply with the requirements of the legal technique in the text of the environmental laws acts leads to such legal errors as adaption of the norms that contradict the Constitution of Ukraine, a reference to the nonexistent norms, incomplete consolidation of circumstances that are essential to the meaning and application of the specific norms of the environmental laws.

The presence of these errors significantly reduces the quality of the acts of environmental legislation, causing difficulties in their interpretation and implementation of the norms of the environmental laws in specific public environmental relations.

\section{SUMMARY}

The problems of the effectiveness of legal regulation of environmental relations have been analyzed in the paper: gaps, collisions, declarative character, contradictions, unclear wording, stylistic shortcomings and other inaccuracies. Prospects for improvement of environmental legislation have been outlined. The main causes of gaps in environmental legislation have been identified. Mechanism to overcome gaps in environmental law is investigated. The author is convinced that one of the main reasons for the low efficiency of the regulatory capacity of environmental law is the existence of collisions. The basic rules to resolve collisions in the legal regulation of 
environmental relations been formulated. The paper emphasizes on interaction of private and public elements of environmental legislation.

\section{REFERENCES}

1. Алексеев С.С. Общая теория права: в 2-х т. М. : Юрид. лит., 1981. T. 1. C. 93.

2. Майстренко О.В. Теоретико-правові аспекти колізій у законодавстві України: автореф. дис. на здобуття наук. ступеня канд. юрид. наук: спец. 12.00.01; Нац. ун-т внутр. справ. Х., 2008. С. 9.

3. Мірошниченко А.М. Колізії в правовому регулюванні земельних відносин в Україні: монографія; Ін-т законодавства Верховної Ради України. К.: Правова єдність, 2009. С. 62.

4. Сидор В.Д. Земельне законодавство України: сучасний стан та перспективи розвитку: монографія. К.: Вид-во “Юридична думка”, 2011. C. 138.

5. Костицький В. Міжнародно-правовий етичний імператив як основа теоретико-методологічного забезпечення розвитку екологічного права. Право Украӥни. 2011. № 2. С. 30.

6. Конституція України, прийнята на п'ятій сесії Верховної Ради України 28 червня 1996 року. URL: https://zakon.rada.gov.ua/laws/show/

\section{Information about the author:} Sydor V. D.,

Doctor of Law, Professor at the Department of Constitutional, Administrative and International Law, Kyiv Institute of Intellectual Property and Law, National University "Odesa Law Academy" 210, Kharkivske highway, Kyiv, 02121, Ukraine 


\section{THE ENVIRONMENTAL CONTENTS OF THE RIGHT TO HIGHER EDUCATION}

\section{Tymoshenko M., Sukhodolska A.}

\section{INTRODUCTION}

In the modern globalized world the higher education acts as a social agent, demonstrating the close interconnection of the personal and social components of the human civilization development ${ }^{1}$. After all, the modernization of social and state development at the present stage is inseparable from the provision of comprehensive development of personality, which, in turn, is impossible without obtaining by the person the educational level for functioning in modern society ${ }^{2}$. It is during the realization of this right a person joins the process of acquiring knowledge, skills, information, that is, providing access to the spiritual and cultural values of human civilization, forming a system of professional adaptation and knowledge for participation in the system of interaction "social production - environment" on the basis of human values, one of the most important of which is the conservation of nature for present and future generations. Such access to values is the most important social need for each person ${ }^{3}$, the satisfaction of which contributes to the creation of favorable ecological and decent economic and social conditions for human and citizen life in not only environmentally safe but also eco-friendly.

At the same time, the realization of such right implies the organization and operation of a network of educational institutions designed to provide educational services to a person at all levels and stages of education. In turn, the process of providing such services must be objective, deriving from science, systematic and further in nature, from lower (pre-school) to higher (higher education) level.

\section{Theoretical and legal content of the right to higher education}

The right to education is under the obligation of the state to provide at least a minimum guarantee to ensure both the accessibility of educational

\footnotetext{
${ }^{1}$ Podolska E. Education in the context of globalization: directions and mechanisms of reform implementation in Ukraine. Higher school, 2007, № 1, pp. 48-55.

${ }^{2}$ Bell D. The Future Post-Industrial Society: The Experience of Social Forecasting. Moscow: Academia, 1999, $783 \mathrm{p}$.

${ }^{3}$ Kostenko O. Culture and Legal - Countering Evil: A Monograph, Kiev: Attica, 2008, $352 \mathrm{p}$.
} 
services within the functioning of the relevant network of educational institutions and the provision of systematic professional knowledge that would take into account the environmental component. Constitutional regulation of higher education and its environmental and ecological and legal components, appropriate programming of the legal consolidation of this brunch of social relations is an objective reflection of the general public significance and functional properties of the phenomenon of higher education for the personality development, society and state development, the embodiment of social value conditions of the globalized civilization development, accompanied by an increase in environmental challenges and threats.

It is about the right to education corresponds not only to the obligation of the state to create state-owned educational establishments and to provide conditions for the establishment and functioning of public and private higher educational institutions on an equal basis ${ }^{4}$. The state ensures the proper functioning of higher education institutions, which should provide the necessary environmental knowledge to specialists in various fields of activity through a system of regulatory, registration, licensing, control and certification measures.

Therefore, the constitutional and legal consolidation of the right to education and forms of its implementation through the higher educational institution activity as an organizational unit activity aims to promote the realization of the human right to higher education as an element of the subjective is key to the constituting the initial principles of the legal regulation of the economic activity of higher educational institutions as well as the right to education in general and the right to obtain professional environmental knowledge necessary for the performance of professional responsibilities in particular. That is, it is about the implementation of the famous scientist prof. V. Kostytskyy proposal on the adoption of the Law of Ukraine "On Environmental Education". His project was developed under his guidance in 1991. In this case, it would also mean introducing an environmental and environmental and legal minimum level of knowledge in the higher education system, and establishing a minimum level of environmental and environmental and legal knowledge in addressing issues related to the hiring and promotion ${ }^{5}$.

\footnotetext{
${ }^{4}$ Shapoval R. The human and citizen constitutional right to education in Ukraine. URl: www.nbuv.gov.ua/portal/soc_gum/pib/2011_1/PB-1/PB-1_5.pdf.; Bonyak V. The human and citizen constitutional right to education and its support in Ukraine: dis. ... Cand. lawyer. Sciences: 12.00.02 / V.O. Bonyak; Nat. Acad. inside. of Ukraine. - Kyiv, 2005, 205 p.

${ }^{5}$ Kostytsky V. Ecology of the transitional period: Law, State, Economy (Economic and Legal Mechanism of Environmental Protection in Ukraine). Institute for Legislative Predictions and Legal Expertise. K.: EUSMEU SME SME, 2003, 772 p. (Series "Ecological Library”; № 5)
} 
Thus, the phenomenon of higher education as an objective social phenomenon is inseparable from the realization of the right to higher education, which denotes the scope of individual personality opportunities to acquire such a complex of diverse knowledge, skills, collectively designated in society and legitimized (officially recognized) by the State as the Higher Education.

There are different conceptual approaches to the definition of the right to higher education and the specifics of its legal support in the legal literature. But all of them are in one way or another dependent on the conceptual view of different scholars of the content and features of the right to education as basic, initial, original. We join the opinion of scholars who believe that the right to education has complex structure and includes a number of relatively independent rights, including the right to higher education ${ }^{6}$.

The right to higher education should be understood as a Governmentguaranteed opportunity for a person who already has the necessary level of basic education to obtain professional knowledge, skills, competences and their official recognition in order to meet the needs of society at a higher educational institution or scientific organization in accordance with established educational programs and standards and the state in training highly qualified specialists, as well as individuals in the intellectual, cultural and moral development with the bank of ecological knowledge of the acquired skills and knowledge implementation ${ }^{7}$. The point of view of the Ukrainian researcher M.O. Rusyn, which defines the right to higher education as the

(Library of the magazine "Small and Medium Business"); Kostytsky V. Organization of Continuous Environmental Education. Collection: Geographical Aspects of Volyn Resource Management. Lutsk, February 14-16, 1991, Lutsk, 1991; Kostytsky V. Environmental Law of Ukraine: [textbook]: 2 books. Drohobych: Circle, 2013, 363 p.; Libanova E. Social stratification of Ukrainian society: an attempt at statistical definition and measurement. Ukrainian Society. 2003, № 1 (2), pp. 146-164.

${ }^{6}$ Zagorodniy S. Contract on vocational training in higher education: author. diss. ... Cand. lawyer. Sciences: 12.00.03 - Civil Law, Family Law, Civil Procedure, Private International Law. Kharkiv. nat. un-t inside. affairs. - Kharkiv, 2007, 20 p.; Myshenko S. The right to higher education in Russia and Germany (comparative legal study): Author's abstract. diss. ... Cand. lawyer. of sciences. Specialty 12.00.02 - Constitutional Law; constitutional litigation; municipal law / S.A. Myshenko; Federal State Budget Educational Institution of Higher Professional Education "Baikal State University of Economics and Law". Irkutsk, 2015, 20 p.; Rusin M. The Right to Higher Education and its Constitutional Support. Comparative and analytical law, 2016, № 5, pp. 234-237.

${ }^{7}$ Todyka $\mathrm{Yu}$. The constitutional and legal status of a person and a citizen in Ukraine. Monograph. Kiev: View, In Yure House, 2004, 368 p.; Shevchuk S. The Concept of State Positive Duties in the Practice of the European Court of Human Rights. Law of Ukraine, 2010, № 2, pp. 55-64; Kostytsky V. Organization of Continuous Environmental Education. Collection: Geographical Aspects of Volyn Resource Management. Lutsk, February 14-16, 1991, Lutsk, 1991. 
legal personality of a person in the acquisition of knowledge, skills, competences etc. in higher educational institution, which correspond to the qualification of a specialist of a higher educational certain level in the relevant field of knowledge and determined by state standards ${ }^{8}$.

Hence, the noted constitutional right consists, in her opinion, of the following eligibilities: 1) the right to higher education funded by budgetary rather than own funds; 2) the right to receive scholarships and other forms of financial support; 3 ) the right to use libraries and information funds free of charge; 4) the right to use university's infrastructure free of charge; 5) the right to provide housing in a hostel free of charge or for a minimal fee'.

In our view, the outlined tendency in the legal literature to "split" the right to higher education into a number of eligibilities objectively has some heuristic potential, although some eligibilities need additional justification. However, the content structuring of the right to higher education makes it impossible to fully comprehend its specificity, not from the inside, but from the outside, namely in the system of other constitutional rights and freedoms of human and citizen. From this point of view, clarification of the essence of the right to higher education will be facilitated by: 1) clarification of the public or private nature of this right; 2) clarification of its relation with natural and positive human rights; 3) clarification of its relation with other environmental, social, economic and cultural rights; 4) study of its relationship with state activities, including the field of environmental protection and features of its implementation ${ }^{10}$.

In modern legal science there is no explicit and well-established conceptual approach to addressing the issues raised above. In particular, in discussions around the nature of the right to higher education - in terms of its affiliation with natural or positive rights - we consider a heuristically unacceptable and low-perspective position, according to which this right belongs exclusively to one or another group of rights, mostly to the category

${ }^{8}$ Rusin M. The Right to Higher Education and its Constitutional Support. Comparative and analytical law, 2016, № 5, pp. 234-237; Melnychuk O. Constitutional and legal support of the right to education in Ukraine in the context of European experience. dis. ... Doc. lawyer. Sciences Specialty 12.00.02 - Constitutional Law; municipal law / OF Melnychuk; Institute of State and Law. V.M. Koretsky NAS of Ukraine, Kyiv, 2015, 459 p. P. 236.

${ }^{9}$ Shapoval R. The human and citizen constitutional right to education in Ukraine. UR1: www.nbuv.gov.ua/portal/soc_gum/pib/2011_1/PB-1/PB-1_5.pdf. P. 7; Bonyak V. The human and citizen constitutional right to education and its support in Ukraine: Dis. ... Cand. lawyer. Sciences: 12.00.02 / V.O. Bonyak; Nat. Acad. inside. of Ukraine. Kyiv, 2005, 205 p. P. 5-6.

${ }^{10}$ Lysenko M. Innovative paradigm of higher education of Ukraine in the conditions of transition to the information society. Author's abstract diss. ... Cand. philosopher. of sciences. Specialty 09.00.10 - Philosophy of Education / M.V. Lysenko; National Technical University of Ukraine "Kyiv Polytechnic Institute". Kyiv, 2013, 19 p. 
of natural rights of the individual. Although, it is really hard to deny that everyone has a right to education since birth. Moreover, when it comes to knowledge related to the environment in the professional field and in life in general.

Likewise, from birth, everyone has the opportunity to pursue higher education after completing the secondary educational level, or even several higher education, which depends solely on the will of the individual. At the same time, we believe that in the modern world the right to higher education, despite its historically (genetically) natural (and therefore inalienable) character, has nevertheless undergone significant positivization at the levels of national and international legal documents. This is confirmed by the regulations documented particular in: Article 26 of the Universal Declaration of Human Rights (1948), Article 2 of Protocol I to the European Convention for the Protection of Human Rights and Fundamental Freedoms (1950), Articles 13, 14 of the International Covenant on Economic, Social and Cultural Rights (1960), Articles 3, 4 Convention on the Elimination of Discrimination in Education (1960), Article 5 of the International Convention on the Elimination of All Forms of Racial Discrimination (1965), Article 10 of the Convention on the Elimination of All Forms of Discrimination against Women (1979), Articles 28, 29 Convention on the Rights of the Child (1989), Article 43 of the International Convention for the Protection of the Rights of All Migrant Workers and Members of Their Families (1990), Article 14 of the EU Charter of Fundamental Rights (2000), Article 24 of the Convention on the Rights of Persons with Disabilities (2006), etc. ${ }^{11}$

\section{Environmental content of the right to higher education}

If classical human rights, also known in the theory of law as first generation rights, were largely aimed at restricting the State power ${ }^{12}$, then the right to higher education, like other educational rights, belongs to the positive, legally binding state rights (the so-called second generation rights), because for its realization it objectively requires the whole complex of actions of the state in to the person of its competent authorities in order to ensure the

${ }^{11}$ Krasnyakov E. International legal acts on education and its influence on the formation of state policy in the field of education of Ukraine. Viche, 2012, № 14. URL: http://www.viche.info/ journal / 3215 /; Pavlyukh O. The right to education: international and national dimension (in the context of the analysis of international treaties and national regulatory acts). Uzhgorod National University Scientific Bulletin, 2014. Pravo Series,Volume 24, Volume 4, pp. 178-181.

${ }^{12}$ Shevchuk S. The Concept of State Positive Duties in the Practice of the European Court of Human Rights. Law of Ukraine, 2010, № 2, pp. 54-55; Todyka Yu. The constitutional and legal status of a person and a citizen in Ukraine. Monograph. Kiev: View, In Yure House, 2004, 368 p., P. 7-8; Kostytsky V., Koban O. Limitation of the Legislature and the Judiciary: A Monograph, Kyiv, “ArtEk Publishing House, 2017, 228 p., P. 27-39. 
quantify of this right. After all, as the well-known Ukrainian constitutionalist S.V. Shevchuk spoke: "upon closer examination of the modern state's role in the realization of fundamental rights and freedoms, it becomes clear that their theoretical distinction, caused by certain contradictions between liberalism and communism, no longer meets the requirements of today. This is due to the fact that all fundamental rights are regarded as positive, as they depend on the state's actions to implement and protect them, and all the rights that are legally enforced become positive. That is, the classical liberal idea that the negative rights correspond to the negative obligation of the State not to interfere with their implementation, is modified by the positive obligation of the State regarding its implementation and guarantee"13.

This regulation is particularly relevant in the context of considering the environmental content of the right to higher education. We believe that in favor of adopting the statement about the mixed - naturally positive - nature of the right to higher education in modern conditions suggests the features of this right as the dependence of its realization on the state policy and socio and economic development of the country, its evolutionary character, as well as programmatically - the purpose of mutual responsibilities of the state and the individual in the higher education ${ }^{14}$. Finally, the "positivization" of the subjective right to higher education is facilitated by its contemporary interpretation as a public-private, not exclusively private law phenomenon, which must take into account the mechanism of its state support ${ }^{15}$. Thus, according to the Ukrainian researcher, O.F. Melnychuk, "the right to education reflects the balance of public and private interests"16. Obviously, this thesis is fully applicable to the field of higher education and its corresponding law.

${ }^{13}$ Shevchuk S. The Concept of State Positive Duties in the Practice of the European Court of Human Rights. Law of Ukraine, 2010, № 2, p. 57; Todyka Yu. The constitutional and legal status of a person and a citizen in Ukraine. Monograph. Kiev: View, In Yure House, 2004, 368 p.

${ }_{14}$ Bell D. The Future Post-Industrial Society: The Experience of Social Forecasting. Moscow: Academia, 1999, 783 p.

${ }^{15}$ Libanova E. Social stratification of Ukrainian society: an attempt at statistical definition and measurement. Ukrainian Society. 2003, № 1 (2), pp. 146-164.; Todyka Yu. The constitutional and legal status of a person and a citizen in Ukraine. Monograph. Kiev: View, In Yure House, 2004, 368 p.; Lysenko M. Innovative paradigm of higher education of Ukraine in the conditions of transition to the information society. Author's abstract diss. ... Cand. philosopher. of sciences. Specialty 09.00.10 - Philosophy of Education / M.V. Lysenko; National Technical University of Ukraine "Kyiv Polytechnic Institute". Kyiv, 2013, 19 p.

${ }^{16}$ Melnychuk O. Constitutional and legal support of the right to education in Ukraine in the context of European experience. dis.... Doc. lawyer. Sciences Specialty 12.00 .02 Constitutional Law; municipal law / of Melnychuk; Institute of State and Law. V.M. Koretsky NAS of Ukraine, Kyiv, 2015, 459 p. P. 92. 
Therefore, we can assert the mixed nature of the right to higher education, which undergoes substantial legal legitimation and positivization in modern society. This approach to this right is also facilitated by the understanding of the phenomenon of higher education itself as a public value, a public good ${ }^{17}$.

In the context of constitutional protection of human rights, we believe that education is an integral part of virtually all human and citizen rights, since without a sufficient level of intellectual development, competences, skills, knowledge, the realization and guarantee any right or civil liberty are impossible. Thus, there is a clear socio and legal relationship between the realization of the right to education, including higher education, and the proper realization of a whole set of other constitutional human and citizen rights. So, A. Melnychuk concludes that "There is a close interaction between the right to education and other constitutional rights, which is expressed in their interdependence, guaranteeing one right by another. Usually, this relationship is so strong that it is sometimes impossible to give preference to one of the rights by determining the level of fulfillment of the guarantee mission over the other" ${ }^{, 18}$. Without the realization of this right, it is impossible to exercise other constitutional rights ${ }^{19}$. For example, the realization of the right to higher education is closely linked to the realization of other constitutional (personal, political, social and cultural) rights of the individual, in particular such as: the right to a decent life (the right to a decent standard of living); the right to work, the right to rest, the right to freedom of literary, artistic, scientific and technical creativity, the right to objects of intellectual property, the right to participate in the management of public affairs, the right to information, the right to a safe and healthy environment etc. The exercise of many of these rights, according to A. Melnychuk, it would be ineffective without the realization the right to education $^{20}$. Beyond this right, it is difficult to exercise the right to use the

${ }^{17}$ Shapoval R. The human and citizen constitutional right to education in Ukraine. URl: www.nbuv.gov.ua/portal/soc_gum/pib/2011_1/PB-1/PB-1_5.pdf.; Bonyak V. The human and citizen constitutional right to education and its support in Ukraine: dis. ... Cand. lawyer. Sciences: 12.00.02 / V.O. Bonyak; Nat. Acad. inside. of Ukraine. - Kyiv, 2005, 205 p.

${ }^{18}$ Melnychuk O. Constitutional and legal support of the right to education in Ukraine in the context of European experience. dis.... Doc. lawyer. Sciences Specialty 12.00 .02 Constitutional Law; municipal law / OF Melnychuk; Institute of State and Law. V.M. Koretsky NAS of Ukraine, Kyiv, 2015, 459 p. P. 130.

${ }^{19}$ Shapoval R. The human and citizen constitutional right to education in Ukraine. URl: www.nbuv.gov.ua/portal/soc_gum/pib/2011_1/PB-1/PB-1_5.pdf.

${ }^{20}$ Melnychuk O. Constitutional and legal support of the right to education in Ukraine in the context of European experience. dis.... Doc. lawyer. Sciences Specialty 12.00 .02 Constitutional Law; municipal law / OF Melnychuk; Institute of State and Law. V.M. Koretsky NAS of Ukraine, Kyiv, 2015, 459 p. P. 162. 
results of scientific progress and the right to choose work ${ }^{21}$. In many cases, having a higher education qualification is a necessary prerequisite for the occupation of many socially important positions and social roles in modern society, including the posts of judges, prosecutors, attorneys, notaries, civil servants, officials of local governments, etc ${ }^{22}$. After all, the acquisition of a higher education person is an additional factor in the formation of a meaningful life position, an adequate level of awareness of the course of social processes, which makes it possible to adapt it in difficult or unfavorable environmental and socio-economic conditions, contributes to active creative behavior. Therefore, higher education becomes a major tool for the creation and multiplication of human capital ${ }^{23}$.

An extensive network of higher educational institutions, as well as other educational institutions, aims to promote the right of citizens of Ukraine to higher education (part one of Article 1 of the Law of Ukraine on Higher Education $^{24}$ ) on the basis of accessibility for every citizen of all forms and types of educational services that provided by the State; equality of conditions of each person for full realization of his abilities, talent, comprehensive development; continuity and diversity of education; (Article 6 of the Law of Ukraine "On Education" 25 ). It is clear that in view of such prolonged delay in the adoption of the Law of Ukraine "On environmental education" it is possible to include provisions on the ecological content of higher education and to take into account the environmental and environmental legal minimum level of the labor in the process of employment and change of position and profession.

${ }^{21}$ Zagorodniy S. Contract on vocational training in higher education: author. diss. ... Cand. lawyer. Sciences: 12.00.03 - Civil Law, Family Law, Civil Procedure, Private International Law. Kharkiv. nat. un-t inside. affairs. - Kharkiv, 2007, 20 p.; Bonyak V. The human and citizen constitutional right to education and its support in Ukraine: Dis. ... Cand. lawyer. Sciences: 12.00.02 / V.O. Bonyak; Nat. Acad. inside. of Ukraine. Kyiv, 2005, 205 p.

${ }^{22}$ Bonyak V. The human and citizen constitutional right to education and its support in Ukraine: dis. ... Cand. lawyer. Sciences: 12.00.02 / V.O. Bonyak; Nat. Acad. inside. of Ukraine. Kyiv, 2005, 205 p. P. 74.

${ }^{23}$ Libanova E. Social stratification of Ukrainian society: an attempt at statistical definition and measurement. Ukrainian Society. 2003, № 1 (2), pp. 146-164; Lysenko M. Innovative paradigm of higher education of Ukraine in the conditions of transition to the information society. Author's abstract diss. ... Cand. philosopher. of sciences. Specialty 09.00.10 - Philosophy of Education / M.V. Lysenko; National Technical University of Ukraine "Kyiv Polytechnic Institute". Kyiv, 2013, 19 p.

${ }^{24}$ On the Higher Education: Law of Ukraine of 01.07.2014 No. 1556-VII // Bulletin of the Verkhovna Rada of Ukraine, 2014, № 37-38, Art. 2004.

${ }^{25}$ On education: Law of Ukraine of May 23, 1991 No. 1060-XII // Bulletin of the Verkhovna Rada of Ukraine, 1991, № 34, Art. 451. 


\section{CONCLUSIONS}

According to this analysis, the subjective right of a person to higher education is an element of the broader content of the right to education, encompassing the elements of environmental and environmental legal education. Such law has a mixed (natural and positive) nature, combines private and public law components in its content, provides for a high level of public and state recognition, including legitimation at the level of positive legislation, and above all at the constitutional level, which makes it possible its enjoyment of other environmental, social, economic and cultural rights.

\section{SUMMARY}

The Article deals with the research of the main issues of the environmental component of the essence and contents of the right to higher education. Leading scientific and theoretical approaches to defining the right to higher education as a set of subjective legal capacity of a person are outlined. The place and role of the right to higher education in the system of subjective human and citizen rights are considered. The essence of the right to higher education clarifies by the determination of the mixed (public-private) nature of this right and its relationship with natural and positive human rights. The research focused on the fact that the enjoyment of other environmental, social, economic and cultural rights depends on the realization of a person's right to higher education. The aspects of interconnection of environmental component of the right to higher education with state activity in the environmental protection are investigated. Suggestions for taking into account prof. V. Kostytsky on the environmental component of vocational education, the continuous environmental education and environmental education support, taking into account the environmental and environmental legal minimum level of knowledge as a condition of appointment to a position and promotion in a position, the need to approve the draft law of Ukraine "On Environmental Education" developed in 1991 and to address this issue - to amend the educational legislation of Ukraine accordingly.

\section{REFERENCES}

1. Kostytskyi V. Ecology of the transitional period: Law, State, Economy (Economic and Legal Mechanism of Environmental Protection in Ukraine). Institute for Legislative Predictions and Legal Expertise. K.: EUSMEU SME SME, 2003, 772 p. (Series "Ecological Library"; № 5) (Library of the magazine "Small and Medium Business").

2. Kostytskyi V. Environmental Law of Ukraine: [textbook]: 2 books. Drohobych: Circle, 2013, 363 p. 
3. Libanova E. Social stratification of Ukrainian society: an attempt at statistical definition and measurement. Ukrainian Society. 2003, № 1 (2), pp. 146-164.

4. Bell D. The Future Post-Industrial Society: The Experience of Social Forecasting. Moscow: Academia, 1999, 783 p.

5. Zagorodniy S. Contract on vocational training in higher education: author. diss. ... Cand. lawyer. Sciences: 12.00.03 - Civil Law, Family Law, Civil Procedure, Private International Law. Kharkiv. nat. un-t inside. affairs. Kharkiv, 2007, 20 p.

6. Myshenko S. The right to higher education in Russia and Germany (comparative legal study): Author's abstract. diss. ... Cand. lawyer. of sciences. Specialty 12.00.02 - Constitutional Law; constitutional litigation; municipal law / S.A. Myshenko; Federal State Budget Educational Institution of Higher Professional Education "Baikal State University of Economics and Law". Irkutsk, 2015, 20 p.

7. Rusin M. The Right to Higher Education and its Constitutional Support. Comparative and analytical law, 2016, № 5, pp. 234-237.

8. Krasnyakov E. International legal acts on education and its influence on the formation of state policy in the field of education of Ukraine. Viche, 2012, № 14. URL: http://www.viche.info/journal/3215/.

9. Pavlyukh $\mathrm{O}$. The right to education: international and national dimension (in the context of the analysis of international treaties and national regulatory acts). Uzhgorod National University Scientific Bulletin, 2014. Pravo Series, Volume 24, Volume 4, pp. 178-181.

10. Todyka $\mathrm{Yu}$. The constitutional and legal status of a person and a citizen in Ukraine. Monograph. Kiev: View, In Yure House, 2004, 368 p.

11. Shevchuk S. The Concept of State Positive Duties in the Practice of the European Court of Human Rights. Law of Ukraine, 2010, № 2, pp. 55-64.

12. Melnychuk O. Constitutional and legal support of the right to education in Ukraine in the context of European experience. dis. ... Doc. lawyer. Sciences Specialty 12.00.02 - Constitutional Law; municipal law / of Melnychuk; Institute of State and Law. V.M. Koretsky NAS of Ukraine, Kyiv, 2015, 459 p.

13. Shapoval R. The human and citizen constitutional right to education in Ukraine. URl: www.nbuv.gov.ua/portal/soc_gum/pib/2011_1/PB-1/PB1_5.pdf.

14. Bonyak V. The human and citizen constitutional right to education and its support in Ukraine: dis. ... Cand. lawyer. Sciences: 12.00.02 / V.O. Bonyak; Nat. Acad. inside. of Ukraine. - Kyiv, 2005, 205 p.

15. Lysenko M. Innovative paradigm of higher education of Ukraine in the conditions of transition to the information society. Author's abstract diss. ... 
Cand. philosopher. of sciences. Specialty 09.00.10 - Philosophy of Education / M.V. Lysenko; National Technical University of Ukraine "Kyiv Polytechnic Institute". Kyiv, 2013, 19 p.

16. On education: Law of Ukraine of May 23, 1991 No. 1060-XII // Bulletin of the Verkhovna Rada of Ukraine, 1991, № 34, Art. 451.

17. On the Higher Education: Law of Ukraine of 01.07.2014 No. 1556-VII // Bulletin of the Verkhovna Rada of Ukraine, 2014, № 37-38, Art. 2004.

18. Kostenko O. Culture and Legal - Countering Evil: A Monograph, Kiev: Attica, 2008, 352 p.

19. Podolska E. Education in the context of globalization: directions and mechanisms of reform implementation in Ukraine. Higher school, 2007, № 1, pp. 48-55.

20. Kostytskyi V. Organization of Continuous Environmental Education. Collection: Geographical Aspects of Volyn Resource Management. Lutsk, February 14-16, 1991, Lutsk, 1991.

21. Kostytskyi V., Koban O. Limitation of the Legislature and the Judiciary: A Monograph, Kyiv, “ArtEk Publishing House', 2017, 228 p.

Information about the authors: Tymoshenko M., PhD., Associate Professor, Vice-Rector of Private Higher Education Institution "European University" 16, Akademika Vernads'koho blvd., Kyiv, 02000, Ukraine ORCID: 0000-0003-2584-5731

Sukhodolska A., Candidate of Law, Senior Lecturer at the Pavlo Tychyna Uman State Pedagogical University, Researcher at the Taras Shevchenko Kyiv National University of Medical Law 60, Volodymyrska str., Kyiv, 01033, Ukraine ORCID: 0000-0002-5794-9167 


\title{
DEVELOPMENT OF SCIENTIFIC OPINION ON THE FORMATION OF NATURAL RESOURCES LAW
}

\author{
Yermolenko V. M., Deineha M. A., Kostytska I. O.
}

\section{INTRODUCTION}

At the turn of the millennium, the priority for the further development of civilization is the harmonization of interactions between society and nature. However, the environmental situation continues to deteriorate, creating a real threat to humanity's existence, and the unrestrained pursuit of economic growth turns to the destruction of natural resource potential. The intensive development of scientific and technological progress has led to the emergence of a number of global environmental problems, each of which is capable of threatening the destruction of civilization.

The need to find an acceptable balance in the relationship between society and nature requires the consolidation of actions of the whole world community aimed at providing a favorable environment with increasing rates of exploitation of natural resources, enhancing anthropogenic impact on the environment. A necessary factor in changing approaches to the use of natural resources has been the transition to a sustainable development strategy, the essence of which is to improve human well-being and strengthen social justice while reducing the risks to the environment and the scarcity of natural resources.

At the same time, addressing environmental issues and socio-economic development is now one of the main activities of any civilized state. Before every country in the world there is a dilemma - how to combine the interests of nature conservation with the interests of economic and social development, how to ensure a systematic consideration of environmental and economic interests, which is a condition for sustainable development as a new paradigm of interaction between society and nature. Ukraine is no exception.

Our country has a strong potential for ecosystem, landscape and species diversity, and at the same time belongs to a group of countries with complex environmental problems. The imbalanced and exhausting use of natural resources is typical of both developing and industrialized countries. The economic growth, that all countries seek and which society expects, will inevitably lead to increased use of natural resources, which in turn increases the anthropogenic burden on the quantitative and qualitative state of natural resources. Existing land-use practices are causing the deterioration of land, and the irrational use of land, forest and water resources leads to irreversible loss of ecosystems and biological diversity. 
Nowadays there is an urgent need to introduce a system of sustainable, environmentally balanced use of natural resources in our country. First of all this implies a change in approaches to their use, taking into account the negative consequences of human interference in the course of natural processes and the balance of interests of development of society and nature. An important role in the process of implementing environmentally balanced use of natural resources will have a natural resource right formed on the basic principles of the concept of sustainable use and conservation of natural resources.

The study of the genesis of scientific thought on the formation of any legal phenomenon helps to uncover the origins and further development of certain social relations that are the object of study, as well as to assess the correctness or error of the mechanism of legal regulation of social relations over a certain time. In this regard, the problematic issues raised are of sufficient scientific interest because it enables one to understand the legal nature of the studied social relations, as well as to find out the place of natural resource law in the system of law and legal doctrine.

The work of such prominent representatives of domestic and foreign legal science, as: V.I. Andreytsev, Yu.O. Vovk, A.P. Hetman, V.M. Yermolenko, B.V. Erofeev, V.A. Zuev, M.D. Kazantsev, I.B. Kalinin, I.I. Karakash, O.S. Kolbasov, V.V. Kostytsky, M.V. Krasnova, P.F. Kulinich, N.R. Malysheva, V.V. Petrov, V.K. Popov, M.V. Shulga and other scientists. However, recognizing the autonomy of natural resource law and determining its place in the legal system remains an urgent problem today.

\section{Formation of natural resources law as an integrated branch of law}

Initially, the subject of environmental law developed within the differentiated (resource) approach to environmental management. At the first stage, the relations that were formed about the use of certain natural resources, especially land, forest and subsoil relations, were subjected to legal regulation. And only in the middle of XX century as a result of society's awareness of global and national problems in the use of natural resources, pollution and degradation of the environment, increasing negative impact on human health, an integrated, ecosystem approach in the field of environmental management has emerged ${ }^{1}$.

The rules governing natural resources relations can be found in the Russian Pravda, the Code of Laws of the Russian Empire, but by the beginning of the XX century as such a system of environmental legislation did

${ }^{1}$ Deineha M.A. Development of scientific thought on the formation of natural resources law. Scientific Bulletin of Uzhgorod National University. 2018. Issue No 49. P. 9. 
not exist. In the early twentieth century resource branches of law (land, forestry, water, subsoil law, etc.) were regarded as separate branches (apparently, to the extent of the general conceptions of the branches of law that existed in those years). Legal norms aimed at regulating the use and protection of natural resources were contained in decrees of the Soviet government "On the socialization of land" (1918), "On the bowels of the earth" (1920), "On forests" (1923), etc. Adoption of the Land and Forest Codes of the USSR was of great importance for regulating resource relations. At that time, there was also no question of natural resource law.

In the 30's of XX century independence of the resource branches of law began to be challenged, since the theory of a unified land-collective farm law prevailed. After obtaining the land right of independence in the 1940s other resource industries began to be incorporated into land law in its "broad sense" . Land law was interpreted as a set of legal norms aimed at regulating not only land, but also mountain, forest, water and other relations related to the use and protection of natural resources ${ }^{3}$.

In fact, land law was, in a broad sense, a prototype of natural resource law, the idea of which was later in the 1960s. put forward M.D. Kazantsev ${ }^{4}$, later supported by leading legal scholars: Yu.O. Vovk, B.V. Erofeev, V.V. Petrov, V.K. Popov, Yu.I. Tyutekin ${ }^{5}$.

M.D. Kazantsev argued that the differentiation of the branches of law governing relations regarding the use and protection of natural resources poses the problem of integration of these branches and the formation of natural resource law ${ }^{6}$. At the same time, the resource branches of law and environmental law, while maintaining their autonomy as branches of law, in the generally accepted sense of the term, form a special part of nature law as an integrated branch of law. The scientist has determined that the natural

\footnotetext{
${ }^{2}$ Kolbasov O.S. Ecology: politics - law. Legal protection of nature in the USSR. Moscow: Science, 1976. P. 147.

${ }^{3}$ Kolbasov O.S. Ecology: politics - law. Legal protection of nature in the USSR. Moscow: Science, 1976. 148 p.

${ }^{4}$ Kazantsev N.D. Natural resources law and its limits as an integrated sector. Bulletin of the Moscow University. 1967. № 6. P. 9.

${ }^{5}$ Vovk Yu.A. Soviet environmental law and environmental protection. The common part: a study guide. Kharkiv: High School, 1986. 317 p.; Erofeev B.V. Soviet natural resource law. Moscow: Law. 283 p.; Popov V.K. Soviet natural resource law and legal environmental protection. A common part. Popov V.K., Vovk Yu.A. and other. Kharkov: Publishing house Khark. state University, 1988. 372 p;. Natural resource law and legal environmental protection / ed. V.V. Petrova. Moscow: Jurid. lit., 1988. 421 p.; Tyutekin Yu.I. Nature, society, law. Chisinau, 1971. P. 219.

${ }^{6}$ Kazantsev N.D. Natural resources law and its limits as an integrated sector. Bulletin of the Moscow University. 1967. № 6. P. 9.
} 
resource right should become a super industry ${ }^{7}$. Yu.I. Tutekin acknowledged the existence of an integrated comprehensive branch of law, but denied the existence of such an integral part as environmental law ${ }^{8}$.

On the advanced theory of M.D. Kazantsev, M.T. Osipov pointed to the "undoubted merit" of a scientist to find a new approach to the problem of improving the effectiveness of the legal regulation of relations, whose objects are land, subsoil, forests, water and other natural resources ${ }^{9}$. At the same time A.S. Kolbasov criticized the position of M.D. Kazantsev. According to the scientist, these statements are of value in themselves only if they are supported by a specific analysis of the content of the proposed branches of law ${ }^{10}$.

At that time, all the attempts of M.D. Kazantsev's withdrawal of the system and structure of natural resource law was reduced to almost the already defined concept of land law in a broad sense.

However, Yu.O. Vovk believed that the existence of the field of natural resource law was obvious ${ }^{11}$. Its subject matter is a kind of public relations regarding the rational use and protection of natural resources. This subject, as noted by the scientist, is unique because of the unity and inseparable connection of all natural resources, as well as the general principles of nature management. At the same time, it is multifaceted, which is reflected in the subspecific diversity of the relations under consideration, caused by different kinds of natural resources, about which there are social relations ${ }^{12}$.

V.V. Petrov pointed out that natural resource law functions in the ecological and legal structure of law together with environmental law and individual legal institutions, legal norms that are part of various branches of law and implement within the regulated relations ecological and legal functions ${ }^{13}$. At the same time, the scientist pointed out that environmental law, unlike the natural resource, which has nature protection sections, regulates the protection of the natural environment in the complex and the unity of its interconnections ${ }^{14}$. V.V. Petrov also supported the idea of independence of natural resource law.

\footnotetext{
${ }^{7}$ The same, p. 8 .

${ }^{8}$ Tyutekin Yu.I. Nature, society, law. Chisinau, 1971. P. 127.

${ }^{9}$ Osipov N.T. Theoretical problems of Soviet land law. Leningrad: Publishing House of Leningrad State University, 1975. P. 21.

${ }^{10}$ Kolbasov O.S. Ecology: politics - law. Legal protection of nature in the USSR. Moscow: Science, 1976. P. 74.

${ }^{11}$ Vovk Yu.A. Soviet environmental law and environmental protection. The common part: a study guide. Kharkiv: High School, 1986. P. 317.

${ }^{12}$ The same, p. 10.

${ }^{13}$ Petrov V.V. Ecology and law. Moscow: "Legal literature", 1981. P. 47.

${ }^{14}$ Legal protection of nature / ed. V.V. Petrova. Moscow, 1980. P. 29.
} 
The design of the integrated mono-branch of natural resource law was proposed by N.B. Mukhitdinov, the main task of which, as noted by the scientist, should be a comprehensive regulation of the most common and important issues of protection and use of natural resources ${ }^{15}$. According to the scientist, overhead, forest, water and land law are correlated with natural resource law as equal, independent elements of a unified system of law ${ }^{16}$. He supported the idea of forming an independent branch of natural resource law and N.T. Razgeldeev ${ }^{17}$.

Thus, based on the scientific idea of M.D. Kazantsev, in the 60-80's of the $\mathrm{XX}$ century. the integrated legal branch - the natural resource law - was formed.

\section{Development of natural resources law in the system of environmental law}

The growing role of environmental social relations in the early 1990s, changes in the political system and related socio-economic and legal processes have adjusted the direction of the development of scientific thought on the formation of natural resource law. These factors, as well as the global ecological crisis and the response of the world community to environmental problems, actually led to the formation of a new position in the development of public relations regarding the use of natural resources and environmental protection - the theory of environmental law, introduced in 1987 by V.V. Petrov ${ }^{18}$. In the system of interaction between society and nature, as noted by the scientist, significant changes have taken place, which led to the strengthening of the consolidation of resource and security relations on the basis of common ecological relations ${ }^{19}$. V.V. Petrov stated as a result of the emergence of a new branch of law - environmental law, on the basis of the consolidation of the natural resource and environmental law.

About this B.V. Erofeev noted that natural resource law is more selfish about the environment than environmental law, which also regulates consumer relations of society, but directs them in such a way that they do not harm the environment as a system of environmental ties, so the objective need

${ }^{15}$ Mukhitdinov N.B. Fundamentals of mountain law: Some important points of theory and practice. Alma-Ata, 1983. P. 136.

${ }^{16}$ The same, p. 137.

${ }^{17}$ Razgeldeev N.T. Responsibility under the Soviet environmental law. Saratov: Publishing house of Sarat. University, 1986. P. 198.

${ }_{18}$ Petrov V.V. The concept of environmental law as a legal community, science and academic discipline. Bulletin of Moscow University. Series 11. Law. 1987. No 5. P. 34-39.

${ }^{19}$ The same, p. 35. 
for social development in modern times the stage is the fastest possible transformation of environmental legislation into environmental law ${ }^{20}$.

From the 90's of the XX century in the field of environmental law on the basis of integration and differentiation formed three basic doctrines of substantive substantiation of environmental law: a) identification with environmental law, which includes two groups of legal relations - rational environmental management and environmental law; b) an integrated supersector with sectoral and sub-sectoral subsystems with three spheres of legal regulation: natural resource; environment protection, landscape; legal support for environmental safety; c) the concept of a comprehensive branch of law that integrates the legal rules governing systematic environmental relations for the protection of life and health of citizens, protection of their environmental rights and freedoms, rational use of the environment and quality of the environment for the benefit of modern and future generations; d) independent differentiated legal branch ${ }^{21}$.

The founder of the theory of environmental law as an integrated, integrated field of law is Yu.S. Shemshuchenko ${ }^{22}$. The scientist defined environmental law as an independent complex branch of law, which is a set of internally interconnected legal norms that regulate environmental social relations in order to implement the state policy in the field of environmental protection and rational use of natural resources, creating favorable environmental conditions for the current and future generations of people ${ }^{23}$. In this case, according to Yu.S. Shemshuchenko, scientifically unconvincing and practically futile, are attempts to prove the existence of two independent integrated branches of law - nature conservation and nature resource law.

The same opinion is followed by N.R. Malysheva. As the scientist points out, natural resource law is a structural part of the complex field of environmental law, as well as land, water, subsoil, forest and faunistic, which in turn are components of natural resource law ${ }^{24}$.

An integrated approach in defining the concept of environmental law is applied by V.I. Andreytsev. According to the scientist, it is an integrated legal community that integrates a set of ecological and legal norms governing ecological relations for the effective use, reproduction, protection of natural

\footnotetext{
${ }^{20}$ Erofeev B.V. Environmental law: textbook. Moscow: The New Lawyer, 1998. P. 87.

21 Deineha M.A. Problems of formation of natural resources law. Scientific Bulletin of the National University of Life and Environmental Sciences of Ukraine: Law series / ed.: S.M. Nikolaenko (chairman) and others. Kyiv, 2015. Vol. 232. P. 60.

${ }^{22}$ Shemshuchenko Yu.S. Legal problems of ecology. Kiev: Naukova Dumka, 1989. P. 206.

${ }^{23}$ The same, p. 64.

${ }^{24}$ Malysheva N., Nepyvoda V. Correlation of natural resource law and environmental law: a new look at the old problem. State and Law. No. 9. 2007. P. 36.
} 
resources, environmental quality assurance, guarantee of ecological safety, realization of protection of environmental rights ${ }^{25}$. V.I. Andreytsev attributes environmental law to an integrated super-industry with sectoral and subsectoral subsystems, aimed at regulating the efficient use of natural resources (environmental resources), ensuring the quality of the environment (environmental relations), safety for life and environmental health (anthropological).

From domestic scientists, a similar opinion was expressed and continues to defend V.V. Kostytsky ${ }^{26}$.

Similar views on the integrated structure of environmental law are expressed by foreign scholars ${ }^{27}$. According to them, environmental law consists of three parts: environmental law and environmental law, as well as environmental protection requirements and environmental rules of law in other branches of law.

The concept of complex regulation of ecological-legal relations is adhered to by M.V. Krasnova, which defines environmental law as a public-law branch, which is based on the legal protection of public interests related to non-property benefits, in particular the interests of the Ukrainian people to realize the right of ownership of natural resources as national wealth, the right to safe and quality natural environment, rights to environmental well-being ${ }^{28}$. On the structure of domestic environmental law as a complex legal branch, according to Y.S. Shemshuchenko, four groups of social relations are crucial: relations with regard to environmental protection; relations on the use of natural resources; relations on ensuring environmental safety; relations concerning the formation, conservation and rational use of the ecological network ${ }^{29}$.

M.V. Shulga views environmental law as an independent (not complex) branch of law with a sub-sectoral structure. The scientist emphasizes that such an approach preserves the integrative unity and species differentiation of environmental law, which is caused by the unity and features of land, water, subsoil, faunistic, atmospheric-air and other varieties of social relations. According to the scientist, the essence of the unity of these relations is that they arise, are effected and terminated in relation to certain natural objects that develop

${ }^{25}$ Andreytsev V.I. Environmental law. General: Lecture Course in Schemes: Tutorial. Kyiv: Venturi, 1996. P. 18.

${ }^{26}$ Kostytsky V.V. Environmental law: textbook. Drohobych: The Circle, 2012. P. 77.

${ }^{27}$ Pankratov I.F. Improving environmental and land law in modern conditions: materials of a scientific and practical conference. State and law. 1996. No. 5. P. 14.

${ }^{28}$ Krasnova M.V. Methodological principles of modern environmental law. Bulletin of Taras Shevchenko National University. Law. 2012. № 92. P. 8.

${ }^{29}$ Environmental Law of Ukraine. Academic course: textbook / ed. Yu.S. Shemshuchenko. 2nd edition. Kyiv: Legal Opinion, 2008. P. 15. 
according to the relevant laws of nature. And all natural objects are collectively interconnected, forming a single ecological system. It is this system that is the objective basis for the existence of a unified environmental relationship. The objectively existing unity of ecological relations is the basis for the corresponding unity of legislation on the regulation of nature management and environmental protection. These relationships are based not only on the social appraisal of specific natural resources and the specific features of their use that result from such appraisal, but also take into account the properties of natural objects, patterns of existence and development of a single nature.

Representatives of the Kharkiv Ecological Law School, led by A.P. Hetman: "the most reasoned is the opinion of those authors who consider environmental law as an independent (non-complex) branch of law with a sub-sectoral structure" 30 .

Recognition in the late 80's of the twentieth century environmental law an independent branch of law and formation in the early 90's of the twentieth century. modern environmental law has been strongly influenced by the more than seventy years of application of the Soviet public-law dogma in the area of legal regulation of the use of natural resources and environmental protection. The Soviet period of development of law practically neutralized the principles of private law in the field of environmental management.

It was during this period that the legal regulation of the use of natural resources and the environment was fundamentally at odds with the development of similar legal mechanisms abroad. If the environmental and environmental law of Europe and the US during the XX century gradually creating more and more compromises in the combination of private law and public law (gradually moving to their parity), then the legal regulation of environmental management in the Soviet period was linked solely to the public legal framework.

However, relations regarding the use of natural resources deserve an independent specific legal regulation, which nowadays can no longer be guaranteed by environmental law. In today's context, it is unnecessary to include these relationships in the context of environmental ones, since the natural resource approach to their regulation cannot be ignored. In this regard, Yu.A. Krasnova emphasizes the need for legal regulation of public relations regarding the use of natural resources, which is due to the interest of society in their detailed regulation, taking into account the specificity of each object ${ }^{31}$.

\footnotetext{
${ }^{30}$ Environmental Law: textbook / ed. A.P. Hetman. Kharkiv: Law, 2013. P. 15.

${ }^{31}$ Krasnova Yu.A. Problems of integration and differentiation in environmental law: the issue of the formation of environmental security law. Problems of integration and differentiation in environmental law: materials of the Round Table (Dnipropetrovsk, September 25, 2014). P. 146.
} 


\section{Establishment of natural resource law as an independent branch of law}

The emergence of the concept of natural resource law as an independent branch of law in the system of law of independent Ukraine belongs to the creative achievement of I.I. Karakash ${ }^{32}$. The scientist notes that such sufficiently developed and widely recognized in the law the natural resource and nature protection social relations cannot be combined within a single branch of law and integrated legal regulation ${ }^{33}$. The scientist draws attention to the untimely integration of these social relations.

I.I. Karakash points out that the positive result of the formation of the natural resource law was the impetus to the development of branches of the domestic resource legislation of the independent Ukrainian state - radical reformation and revival of land law, significant renewal of water, forest and subsoil law, as well as the formation of faunistic ${ }^{34}$. That is why natural resource law in the long run should really claim to play a fundamental branch of law in the Ukrainian legal system.

Natural resources relations, as noted by I.I. Karakash are complex in that they combine land, subsoil, water and forest relations, as well as relations regarding the use of fauna and flora and other natural resources, leaving the specifics of legal regulation of their use within the respective differentiated branches of resource legislation ${ }^{35}$. This complex of relations is formed on the basis of integration only common in content of land, subsoil, water, forest and other natural resources relations. According to the scientist, natural resource law in the Ukrainian legal system is a separate and complex set of legal rules governing resource relations in order to ensure the rational use of natural objects and their resources, as well as their timely and effective reproduction $^{36}$.

Similar views are shared by other scholars, albeit from different scientific positions and justifications. However, the completeness of natural resource law as an independent branch of law does not cause any doubt to any of these scientists.

Thus, V.M. Yermolenko points out that the environmental-legal doctrine artificially attracted environmental law at the level of the structural

${ }^{32}$ Natural resources law of Ukraine: textbook / ed. I.I. Karakash. Kiev: The Truth, 2005. P. 376.

${ }^{33}$ Karakash I.I. The subject and system of natural resource law. Natural resources law of Ukraine: textbook / ed. I.I. Karakash. Kiev: Truth, 2005. P. 14.

${ }^{34}$ The same.

35 Karakash I.I. On the differentiated and integrated concept of natural resources and environmental law. Problems of integration and differentiation in environmental law: materials of the round table (Dnipropetrovsk, September 25, 2014). Dnepropetrovsk: NSU, 2014. P. 88.

${ }^{36}$ The same. 
component $^{37}$. At the same time, as the scientist points out, nowadays natural resource law must be recognized as an independent branch of law, which unites the rules of law, which determine the general principles of establishing the ownership of natural resources, forms and methods of rational use of nature, the procedure for granting permits for special nature use, features of the process restoration of disturbed natural resources and the like. These rules, according to V.M. Yermolenko, will represent in the classical sense a common part for each of the existing resource sectors ${ }^{38}$.

Foreign scientists also uphold the concept of independence of natural resource law. I.B. Kalinin points out that from the very beginning of the formation of natural resource law as an independent branch, environmental (environmental) law was included in its subject, since historically the use of natural resources began much earlier than the need for their protection arose ${ }^{39}$. The scientist regards natural resource law as an independent branch of law, the subject of which is a set of relations related to the extraction of natural resources. Within the framework of such relations, the scientist distinguishes the so-called: 1) resource (relations concerning the direct extraction of natural resources from the environment of their finding, as well as their related relations with search, evaluation, exploration); 2) relationships that are closely related to the resource: relationships that precede the resource; relations on the safety and rationalization of environmental management; ownership of natural resources; public resource management relations; relations concerning the holding of subjects of natural resources right to account and for the consideration of disputes arising from the use of natural resources and compensation for the harm caused by their misuse ${ }^{40}$. G.V. Chubukov draws attention to the fact that the substantive characteristic of the natural resource law is determined by: the presence of specific natural resource relations, which are related to the satisfaction of vital human needs at the expense of natural benefits; the peculiarities of the object of legal regulation on which legal rules are drawn up ${ }^{41}$.

37 Yermolenko V.M. Natural resources law in the system of law of Ukraine. Natural Resources Law in the Law System of Ukraine: History, Present, Prospects: Collection of Round Table Materials (Kharkiv, October 30-31, 2015) / ed. M.V. Shulga. Kharkiv: Yaroslav the Wise National Law University, 2015. P. 88.

${ }^{38}$ Yermolenko V.M. Theoretical problems of differentiation of branches of environmental and natural resources law. Law of Ukraine. 2010. № 6. P. 148.

${ }^{39}$ Kalinin I.B. Natural resource law: training manual. Tomsk: Publishing House Tom. University, 2009. P. 82.

${ }^{40}$ The same, p. 112.

${ }^{41}$ Kalinin I.B. Natural resource law: training manual. Tomsk: Publishing House Tom. University, 2009. P. 6. 
Recognizing the independence of natural resource law, Belarusian scientists characterize it as a complex branch of law, which is a set of legal norms that regulate social relations between people in the process of environmental management to meet the socio-economic needs and in general the development of the state ${ }^{42}$.

So, at the beginning of the XXI century on the basis of scientific ideas I.I. Karakash formed the concept of independence of natural resources law, which has found support among domestic and foreign scientists. At the same time, neither the priority development of environmental law with the integration into its structure of natural resources relations, nor the strengthening of greening of resource industries in modern conditions should not deny the need to form and become a branch of natural resources law in the system of law of independent Ukraine.

The legal nature of natural resource relations is the subject of research and outstanding scientists of ecological and legal doctrine - supporters of the opposite scientific position. V.I. Andreytsev points out that natural resource relations consist mainly of the use and restoration of specific natural resources as the main means of management, production and conditions of human life, to meet the spiritual, material, therapeutic, aesthetic, recreational, cultural and educational needs and other needs ${ }^{43}$. P.F. Kulinich defines natural resource relations as a set of complex social relations regarding the use and reproduction of certain natural resources in their inextricable connection with other elements of the environment ${ }^{44}$.

At the same time, in VI's view Andreytseva, to speak about natural resource law as an independent branch of law is nothing but to distort the objects of this right, which will lead to rupture of their dialectical unity with landscapes and natural complexes, ensuring safe conditions of conservation and protection, including prevention of negative impact on the human life environment. Therefore, according to the scientist, the greatest social, economic, environmental effect can be achieved in a harmonious combination of natural resources and other components of the sphere of life (biosphere) while ensuring and solving all problems of sustainable development ${ }^{45}$.

42 Markina N.A. Natural resource law: lecture course. Vitebsk: VSU named after P.M. Masherova, 2017. P. 6.

${ }^{43}$ Andreytsev V.I. Environmental law. General: Lecture Course in Schemes: Tutorial. Kyiv: Venturi, 1996. P. 97.

${ }^{44}$ Kulinich P.F. Natural law as a legal phenomenon: polemical aspects. Natural Resources Law in the Law System of Ukraine: History, Present, Perspectives: Collection of Round Table Materials (Kharkiv, October 30-31, 2015) / in total. ed. M.V. Shulga. Kharkov: Issue of Oberg Ltd., 2015. P. 152.

${ }^{45}$ Andreytsev V.I. Prospects for the development of natural resource law in the system of environmental law of Ukraine. Natural Resources Law in the Law System of Ukraine: History, 
P.F. Kulinich points out that the idea of natural resource law has not reached the level of scientific theory in its development, remaining a scientific hypothesis, which is not confirmed by practice. According to the scientist, this is due to the absence of the subject of natural resource law - a clear, "sensitive" to the legal influence of the system of social relations, which could be qualified as natural resources relations ${ }^{46}$.

M.V. Krasnova, not recognizing natural resource law as an independent branch of law, characterizes it as: a generic term that is used to refer to a group of branches of law having a common subject, namely: legal relations in the use, protection and reproduction of natural resources; the field of legal science and relevant scientific specialty; a discipline that was taught predominantly in higher education in the $1980 \mathrm{~s}^{47}$.

Indeed, most well-known scientists do not share the aforementioned approaches to the development of environmental law outside of environmental law, but in so doing, giving environmental law almost the most important place in the environmental law system. This scientific debate on finding out the place and legal affiliation of natural resources relations, recognizing the independence of natural resources law in the legal system dates back more than half a century and is still an urgent issue.

The current stage of development of natural resource law is characterized by the lack of a generally recognized approach to determining its place in the system of law. From the very beginning of the establishment of natural resource law as an independent branch, environmental law was included in its subject, since historically the use of natural resources began much earlier than the need for their protection arose. Therefore, at the stages of the formation of environmental law it seemed natural to include environmental relations in the subject of legal regulation.

In the future, scientific literature has suggested that environmental law has outgrown the natural resource framework, since it has the task of protecting not only a particular natural resource but also nature as a whole. The obvious link between the use and protection of natural resources has led to the incorporation of environmental law into environmental law

\footnotetext{
Present, Prospects: Collection of Round Table Materials (Kharkiv, October 30-31, 2015) / ed. M.V. Shulga. Kharkiv: Yaroslav the Wise National Law University, 2015. P. 10.

${ }^{46}$ Kulinich P.F. Natural law as a legal phenomenon: polemical aspects. Natural Resources Law in the Law System of Ukraine: History, Present, Perspectives: Collection of Round Table Materials (Kharkiv, October 30-31, 2015) / in total. ed. M.V. Shulga. Kharkov: Issue of Oberg Ltd., 2015. P. 154.

${ }^{47}$ Krasnova M.V. Modern realities of the natural resource law of Ukraine. Natural Resources Law in the Law System of Ukraine: History, Present, Prospects: Collection of Round Table Materials (Kharkiv, October 30-31, 2015) / ed. M.V. Shulga. Kharkiv: Yaroslav the Wise National Law University, 2015. P. 143.
} 
(environmental law), or as a sub-branch, or as a collection of individual sub-sectors (water, forest, subsoil, faunistic, etc.).

Mechanical movement of the set of rules governing public relations on the use of natural resources from one branch of law to another, did not change, and could not change the nature and specifics of natural resource relations, turn relations on the use of natural resource in relations with its protection. The content of natural resource relations as a public relation to the use of natural resources and related relations has not changed for many centuries and is independent of the content of conservation activities. Natural resource relations consist of the use and reproduction of natural resources or their properties (for example, the potential energy of water, which is converted into electricity, the surface of water for water transport, the properties of atmospheric air to accommodate and dissolve (reduce concentration) pollutants, the property of subsoil in underground gas storage, etc.), and environmental relations are aimed at protecting the natural object or the environment as a whole and are not relevant as many natural objects as the internal and external relations of these objects, their properties, states and processes occurring in them.

Therefore, the subject of legal regulation of natural resources law should be considered public relations on the use and reproduction of natural resources as a legally defined part of the environment, which has signs of natural origin and is in ecological connection with other natural resources, potentially or actually valuable for humanity, used or can be used as a source of material and spiritual benefits ${ }^{48}$. In this case, natural resource relations are complex in nature, because they unite in their content land, water, forest, subsoil and other relations, defining the general principles of their legal regulation, while leaving the specific legal regulation of the use and reproduction of certain natural resources within the relevant resources. areas of law (land, water, forest, etc.).

The subject matter of the law is that any set of social relations must be a systemic phenomenon, based on objective systemic factors and links that unite the various social relations. The unity of the field of environmental law is due to the presence of systemic factors, which include the subject, object and method of legal regulation, which are the determining criteria for the construction of the system of environmental law.

The system of natural resources law can be defined as an integrated and organized set of legal norms, which are interconnected by internal relations and regulate public relations on the use and reproduction of natural resources

48 Deineha M.A. Natural Resources Law: Problems of Formation and Development: Monograph / by general. ed. V.M. Yermolenko. Kyiv: NULES of Ukraine, 2019. P. 87. 
in their inextricable connection with other elements of the environment in order to meet the needs of human, society and state ${ }^{49}$.

\section{CONCLUSIONS}

The system of natural resource law is characterized by an internal organizational structure. It is objectively conditioned by natural resources relations its division into separate interrelated elements: legal norms, institutes, sub-branches. In addition, the structure of the natural resource law system can be represented by dividing it into general and special parts. The common part of natural resource law includes a number of legal institutions that contain norms of common law and are common to all types of natural resource relations that are subject to legal regulation. Institutions of the Common Law on Natural Resources include: ownership of natural resources; the right to use natural resources; legal regulation of reproduction of natural resources; legal support for management in the field of use and reproduction of natural resources; legal responsibility for violations of environmental legislation. The legal norms and institutions of a particular part regulate certain relatively separated groups of social relations and have a lesser degree of generality. The norms of these institutes are aimed at taking into account the peculiarities of different types of natural resource relations. Relations arising from the use of certain types of natural resources are governed by the rules included in the Special Part: Land Law; water law; forest law; subsoil right; floristic law; faunistic law.

At present, all objective prerequisites have been formed and there is every reason to argue for the formation of an independent branch of law - natural resource law, separation and separation of it from the environmental structure. The fundamental differences between environmental law and environmental law are reflected in the subject matter and object of the legal regulation, the method and its sources. Natural resources law regulates public relations, which consist of the use and reproduction of natural resources, while the subject of environmental (environmental) law is public relations concerning the protection of natural objects and the environment in general, internal and external relations, natural objects, their properties, states and processes occurring in them. The use of natural resources and the protection of the environment are different forms and forms of interaction between society and nature in their goals and objectives. The first is designed to meet the various needs of man and society, and the ultimate goal of protecting the environment is to achieve its quality.

49 Deineha M.A. Natural Resources Law: Problems of Formation and Development: Monograph / by general. ed. V.M. Yermolenko. Kyiv: NULES of Ukraine, 2019. P. 171. 
Natural resources law should be considered as an independent branch of law in the system of law of Ukraine, the legal rules of which regulate complex public relations on the use (extraction and consumption of useful properties) and reproduction (restoration of quantitative and qualitative characteristics) of natural resources that have potential or actual value for human beings and is the source of the necessary material and spiritual benefits.

\section{SUMMARY}

The section of the monograph is devoted to the research of scientific approaches to the formation of natural resources law, to find out the place of natural resources law in the legal system. The theoretical positions of representatives of legal science concerning the definition of the subject of legal regulation, peculiarities of nature-resource relations are revealed. The scientific approaches to the relation of natural resource law with environmental protection and environmental law are analyzed.

\section{REFERENCES}

1. Andreytsev V.I. Environmental law. General: Lecture Course in Schemes: Tutorial. Kyiv: Venturi, 1996. 208 p.

2. Andreytsev V.I. Prospects for the development of natural resource law in the system of environmental law of Ukraine. Natural Resources Law in the Law System of Ukraine: History, Present, Prospects: Collection of Round Table Materials (Kharkiv, October 30-31, 2015) / ed. M.V. Shulga. Kharkiv: Yaroslav the Wise National Law University, 2015. P. 9-15.

3. Bobylev A.K., Belashenko S.A. Questions of the theory of environmental law. Minsk, 1991. 203 p.

4. Vovk Yu.A. Soviet environmental law and environmental protection. The common part: a study guide. Kharkiv: High School, 1986. 317 p.

5. Deineha M.A. Natural Resources Law: Problems of Formation and Development: Monograph / by general. ed. V.M. Yermolenko. Kyiv: NULES of Ukraine, 2019. $340 \mathrm{p}$.

6. Deineha M.A. Problems of formation of natural resources law. Scientific Bulletin of the National University of Life and Environmental Sciences of Ukraine: Law series / ed.: S.M. Nikolaenko (chairman) and others. Kyiv, 2015. Vol. 232. P. 58-64.

7. Deineha M.A. Development of scientific thought on the formation of natural resources law. Scientific Bulletin of Uzhgorod National University. 2018. Issue No 49. P. 9-11.

8. Environmental Law of Ukraine. Academic course: textbook / ed. Yu.S. Shemshuchenko. 2nd edition. Kyiv: Legal Opinion, 2008. 848 p. 
9. Environmental Law: textbook / ed. A.P. Hetman. Kharkiv: Law, 2013. $272 \mathrm{p}$.

10. Erofeev B.V. Soviet natural resource law. Moscow: Law. 283 p.

11. Erofeev B.V. Environmental law: textbook. Moscow: The New Lawyer, 1998. 688 p.

12. Yermolenko V.M. Natural resources law in the system of law of Ukraine. Natural Resources Law in the Law System of Ukraine: History, Present, Prospects: Collection of Round Table Materials (Kharkiv, October 30-31, 2015) / ed. M.V. Shulga. Kharkiv: Yaroslav the Wise National Law University, 2015. P. 88-91.

13. Yermolenko V.M. Theoretical problems of differentiation of branches of environmental and natural resources law. Law of Ukraine. 2010. № 6. P. 348-351.

14. Kazantsev N.D. Natural resources law and its limits as an integrated sector. Bulletin of the Moscow University. 1967. № 6. P. 6-9.

15. Kalinin I.B. Natural resource law: training manual. Tomsk: Publishing House Tom. University, 2009. 350 p.

16. Karakash I.I. The subject and system of natural resource law. Natural resources law of Ukraine: textbook / ed. I.I. Karakash. Kiev: Truth, 2005. P. 5-41.

17. Karakash I.I. On the differentiated and integrated concept of natural resources and environmental law. Problems of integration and differentiation in environmental law: materials of the round table (Dnipropetrovsk, September 25, 2014). Dnepropetrovsk: NSU, 2014. P. 87-93.

18. Kolbasov O.S. Ecology: politics - law. Legal protection of nature in the USSR. Moscow: Science, 1976. 232 p.

19. Kostytsky V.V. Environmental law: textbook. Drohobych: The Circle, 2012. $360 \mathrm{p}$.

20. Krasnova M.V. Methodological principles of modern environmental law. Bulletin of Taras Shevchenko National University. Law. 2012. № 92. P. 5-8.

21. Krasnova M.V. Modern realities of the natural resource law of Ukraine. Natural Resources Law in the Law System of Ukraine: History, Present, Prospects: Collection of Round Table Materials (Kharkiv, October 30-31, 2015) / ed. M.V. Shulga. Kharkiv: Yaroslav the Wise National Law University, 2015. P. 143-146.

22. Krasnova Yu.A. Problems of integration and differentiation in environmental law: the issue of the formation of environmental security law. Problems of integration and differentiation in environmental law: materials of the Round Table (Dnipropetrovsk, September 25, 2014). P. 145-151. 
23. Kulinich P.F. Natural law as a legal phenomenon: polemical aspects. Natural Resources Law in the Law System of Ukraine: History, Present, Perspectives: Collection of Round Table Materials (Kharkiv, October 30-31, 2015) / in total. ed. M.V. Shulga. Kharkov: Issue of Oberg Ltd., 2015. P. 152-155.

24. Malysheva N., Nepyvoda V. Correlation of natural resource law and environmental law: a new look at the old problem. State and Law. No. 9. 2007. P. 31-40.

25. Markina N.A. Natural resource law: lecture course. Vitebsk: VSU named after P.M. Masherova, 2017. 49 p.

26. Mukhitdinov N.B. Fundamentals of mountain law: Some important points of theory and practice. Alma-Ata, 1983. $333 \mathrm{p}$.

27. Osipov N.T. Theoretical problems of Soviet land law. Leningrad: Publishing House of Leningrad State University, 1975. 320 p.

28. Pankratov I.F. Improving environmental and land law in modern conditions: materials of a scientific and practical conference. State and law. 1996. No. 5. P. 121-125.

29. Petrov V.V. The concept of environmental law as a legal community, science and academic discipline. Bulletin of Moscow University. Series 11. Law. 1987. No 5. P. 34-39.

30. Petrov V.V. Ecology and law. Moscow: "Legal literature", 1981. $224 \mathrm{p}$.

31.Popov V.K. Soviet natural resource law and legal environmental protection. A common part. Popov V.K., Vovk Yu.A. and other. Kharkov: Publishing house Khark. state University, 1988. 372 p.

32. Legal protection of nature / ed. V.V. Petrova. Moscow, 1980. $312 \mathrm{p}$.

33. Natural resources law of Ukraine: textbook / ed. I.I. Karakash. Kiev: The Truth, 2005. $376 \mathrm{p}$.

34. Natural resource law and legal environmental protection / ed. V.V. Petrova. Moscow: Jurid. lit., 1988. 421 p.

35. Razgeldeev N.T. Responsibility under the Soviet environmental law. Saratov: Publishing house of Sarat. University, 1986. 198 p.

36. Tyutekin Yu.I. Nature, society, law. Chisinau, 1971. 219 p.

37. Chubukov G.V. Natural resource law of the Russian Federation: textbook. Moscow: MGIU, 2007. 276 p.

38. Shemshuchenko Yu.S. Legal problems of ecology. Kiev: Naukova Dumka, 1989. 206 p.

39. Shulga M.V. Current legal problems of land relations in modern conditions. Kharkov: Consum, 1998. 224 p.

40. Yakovlev V.N. Environmental law: textbook. Chisinau, 1988. 344 p. 


\section{Information about the authors:}

Yermolenko V. M.,

Doctor of Law, Professor,

Head of the Academician V.Z. Yanchuk Department

of Agrarian, Land and Environmental Law,

National University of Life and Environmental Sciences of Ukraine

15, Heroiv Oborony str., Kyiv, 03041, Ukraine

ORCID: 0000-0002-4295-4158

ResearcherID: Y-1490-2018

Deineha M. A.,

Candidate of Law, Associate Professor,

Associate Professor of the Academician V.Z. Yanchuk Department of Agrarian, Land and Environmental Law, National University of Life and Environmental Sciences of Ukraine

15, Heroiv Oborony str., Kyiv, 03041, Ukraine

ORCID: 0000-0002-4785-7509

ResearcherID: Y-1361-2018

Kostytska I. O.,

Candidate of Law Sciences, Senior Researcher, Deputy Head of the Department of the Institute of Legislation,

Verkhovna Rada of Ukraine 5, Mykhaila Hrushevskoho str., Kyiv, 01008, Ukraine

ORCID: 0000-0003-2336-1426 


\section{LEGAL AND ORGANIZATIONAL SUPPORT FOR THE LAND REFORM BY THE P. STOLYPIN GOVERNMENT}

\section{Zakharchenko P. P.}

\section{INTRODUCTION}

Political and legal prerequisites that formed in the country at the beginning of the 20-th century matured before a cardinal decision was made. They were pushed by the head of the state himself. At a meeting with the peasant delegation in January, 1905 in Tsarskoe Selo, Nicholas II outlined ways of implementing the land reform. He unambiguously declared the inadmissibility of the liquidation of the landed estates the delegates insisted on. "The land owned by the landlords belongs to them in the same inalienable right that your land belongs to you"1, - this replica of the emperor would later be repeatedly relayed, first of all by P. Stolypin, who would act within the frames defined by Nicholas II.

Finally, on November 9, 1906 nominal decree of Governing Senate "On amending some regulations of the present law relating to peasant land tenure and land use" allowed "each homeowner who owns the allotment of land by public law, to require the transfer of personal property due to his part of the designated land". If no redistribution of land had been carried out in communities for 24 years, it was transferred into personal property without a compensation to the community (Section 1, Article 2). "The allotted land of the court is privately owned and does not require documentary evidence",- such a statement of the Ministry of Internal Affairs of August 4, 1907 under No. 23792 de jure without unnecessary procedures recognized a considerable percentage of peasants of Ukrainian provinces as the owners of the lands. Otherwise, individual homeowners purchased land plots for free only when in their families the number of audit souls after the last redistribution had not decreased. Otherwise, the homeowner was obliged to make payments to the community in the amount of the initial average purchase price of one tenth for the surplus plot (Article 3).

As the civil legislation of the Russian Empire did not contain a definition of "personal property", the Chairman of the Council of Ministers, State Secretary P. Stolypin, at the insistence of the State Duma deputies, was forced

\footnotetext{
${ }^{1}$ Боханов А.Н. Последний царь. М. : Вече, 2006. 512 с.

2 Закон 9 ноября 1906 года о выходе из общины, с разъяснениями. М. : Юристь, 1908. $85 \mathrm{c}$.
} 
to clarify the Government's understanding of the mentioned legal definition. On December 5, 1908, in a speech at the session of the State Duma of the third convocation, he stated: "An individual owner in accordance with the text of the law has the right to dispose of his land, may acquire it as well as may require to transfer some of its plots to one place; he may purchase land for himself additionally as well as to mortage it in the Peasant Bank; finally, he may sell it"3.

At the same meeting P. Stolypin as the representative of the subject of representation of the legislative initiative, expressed himself about the main idea of the law. According to the head of the Council of Ministers, it was necessary "where the personality of the peasant has developed to some extent and where the community, as a forced union, impedes his activity... to give him the freedom to work, to get rich, to dispose of his property, to give him power over the land"4.

\section{Nominal Decree to the Governing Senate "On the Supplement to Some Resolutions of the Present Law Concerning Peasant Land Tenure and Land Use" November 9, 1906 : Characterization of the Source of Law}

After all it was the community as a hotbed of accumulation of left-wing radical ideas that the authorities considered a real threat to their existence. No wonder, one of the members of the State Duma, A. Eropkin, expressing the sentiments of the right circles of the political spectrum, warned: "The community denies the right for private land ownership; and this denial penetrated so deeply into the minds of the members of the community that it consistently came as far as the point of not accepting the property at all"5. Such sentiments in the right segment of the political landscape P. Stolypin also belonged to, were far from unique.

According to the provisions of the Law of November 9, 1906, peasants of all names who had purchased plots of public land into private ownership continued to retain the right of use with unchanged share, as well as up to the moment of the declaration of intention to transfer to personal possession, and of those lands, which were distributed on special grounds (hayfields, forests, etc.). Similarly, their rights were maintained, according to the community's customs in force for worldly homesteads, pastures, pastures, vows.

3 Александровский Ю.В. Закон 14 июня 1910 года об изменении и дополнении некоторых постановлений о крестьянском землевладении. СПб. : Товарищество по изданию новых законов, 1911. $608 \mathrm{c}$.

${ }^{4}$ Столыпин П.А. Думские речи. М : Знание, 1990. 64 с. (Новое в жизни, науке, технике. Серия “Лекторское мастерство”. № 10).

${ }^{5}$ Бородин А.П. Реформы во имя России. М. : Вече, 2002. 380 с. 
Article 16 clarified that peasant homeowners, having acquired land on personal property rights, enjoy the same rights with the owners of the yards. That is, the heirs of the former continued to retain the right to participate in the use of lands which were allocated under special conditions, and of those that ones were not distributed at all by the decision of the community.

In view of the problem we are investigating, the third section of the analyzed Law is of major importance to us. It is this law that covers the legal personality of the owner of the land, the volume of his rights and the mechanism of securing public land as his personal property. "Yard plots Article 1 of Section 3 reads - granted to the peasant yard posession of the peasants upon their allotment of land and acquired later into the personal property of individual peasants from public lands as well as yard plots in public land use, constitute the personal property of the landowners, on whom these plots are designated in accordance with the acts of land management, decisions of communities, decisions of peasant bodies, acts of alienation and decisions of court places" ${ }^{\prime 6}$. It was the courts space, and in this case that county courts that were made responsible for solving the homeowners question in case of his absence in the family. According to the area's custom in force, the courts approved the relevant decision, taking into account the following circumstances: to whom of the members of the family, by distribution or last redistribution, the allotment was given; on whose name the payment book was written; who paid the duties; who by the time of acquisition, actually owned and cultivated the allotment ${ }^{7}$.

As we can see, the text of the Decree of November 9, 1906 does not answer the question of the concrete owner of the land holdings. The Western provinces with a yard form of use of allotment land, including the Podolsk and Volyn, gubernias are taken as a standard. For these reasons, the law did not apply to them. It was here that the rule had long been enrooted that the land belonged not to the yard, but to the homeowner as the head of the family. In short, according to the Decree of 9 November 1906, yard plots in the yard posession transferred into personal property from the public allotment land as well as homesteads in public ownership, were recognized as the property of the homeowner (father or grandfather), but not that of the family in its full composition. This conclusion is prompted by the absence of any other

6 Закон 9 ноября 1906 года о выходе из общины, с разъяснениями. М. : Юристь, 1908. $85 \mathrm{c}$.

${ }^{7}$ Соловьев И. Юридическое наставление крестьянам как укрепить в собственность земельный надел и как владеть землею на правах собственника с приложением Закона 14-го июня 1910 года. М. : Типография “Наше слово”, 1911. 32 с. 
interpretation of the concept of "personal land ownership" than we have found the previously issued and analyzed normative legal acts.

Such is the logics of our speculations. However, the opinion of the Governing Senate was different. With the passing of the well-known Decree, the Senate faced a large number of complaints, statements and protests and thus interpreted the mentioned norm in another way. The Second department of the Senate on 31.01.1907 (№ 735) approved the decision unexpected for the contents of the decree: "Data on land allotments bought by peasant are issued to the name of the homeowner, while the plot is considered belonging to the whole yard" ${ }^{8}$. So, the right for land ownership after its acquisition as private property continued to belong to the peasant yard.

Meanwhile, common property included indivisible plots of land of few people who did not have family vertical ties (Section 3, Article 2). As noted, as the joint ownership of Art. 543 Vol. X Part 1 of the Laws of Civil Law recognized such a type property where the right for one thing belongs to several persons, each of them having full powers only on a known part of the thing ${ }^{9}$. In the context of Article 2, Section 3, the Decree refers to the indivisible land plots of several persons. Of course, the majority of such persons were mothers, brothers, uncles, nephews or other relatives on a side rather than a straight line ${ }^{10}$. If it was such persons who concentrated the powers of the homeowner, the land plots constituted the joint ownership of the host, jointly with the side relatives. Contemporary lawyers have argued not without grounds that in this case the latter had the right to demand the allocation of their share of movable and immovable property from joint ownership. However, in order to achieve this goal, it was necessary to obtain the consent of the homeowner for legal family distribution. Children not separated from their parents' state were not allowed to require the transfer of ownership to their own names (MIA Circulars of 23 November 1905 and 6 June 1907).

Consequently, the statutory provisions of the Decree governed the procedure for leaving public custody. For this purpose, it was assumed that those wishing to leave the community and to allocate the land allotment from

\footnotetext{
${ }^{8}$ Тютюрмов И.М. Закон 14 июня 1910 года об изменениях и дополнениях некоторых постановлений о крестьянском землевладении с законодательными мотивами и разъяснениями Правительствующего Сената (по 1 сентября 1910 года). - [изд. неоф.] СПб.: Издание юридического книжного магазина И.И. Зубкова под фирмою “Законоведение", 1911. 181 с.

${ }^{9}$ Семенов Е.В. Краткие сведения по русскому земельному праву : пособие [для учеников землемерных училищ]. Псков : Тип. губернского земства. 35 с.

${ }^{10}$ Дроздов В.П. Крестьянские законы. Права крестьян на землю. М. : Тип. П.П. Рябушинского, 1910.39 с.
} 
the land use had to apply to the village elder. The latter, in his turn, was to convene a village assembly, which within one month from the date of the application was obliged to make a decision on the transfer of land on the right of personal property. Half of homeowners were required to make a decision, and at least half of the participants of the meeting were to vote for the decision to transfer the land into personal property.

It should be noted that the legislator did not envisage a possibility of turning down the allocation of land to the homeowner. In the event of the community not wanting the land to be allotted, the applicant was allowed to contact the local governor or other officials. The chiefs of the country or the persons who replaced them were to satisfy the request of the homeowner immediately. For this purpose, the officials had to go to the place, to draw up an appropriate act to reflect the parameters of the lands that were subject to transfer to the personal property of those wishing to leave the community. In case of delay of the procedure by the district governors, the homeowner could apply to the local provincial administration.

The decisions of rural communities as well as rural chiefs' decrees entered into force and were performed only after their approval by their county congresses. It was here that complaints of both homeowners who had purchased the land into personal property and authorized for that representatives of the community were handled.

Despite the extension of the powers of the homeowner to allotment lands, the legislator did not eliminate the legal restrictions laid down in the Regulations of February 19, 1861 and expanded by the decree of December 14, 1893 "On the inalienability of allotment lands". Restrictive norms regarding the sale of allotment land to peasants belonging to the seller's communities continued to apply.

An important instrument for the implementation of the state's land policy was the provision on the possibility of transition of entire communities with both public and backyard land use to household cut land. It should be noted that departures to household cuts be made, as some authors mistakenly claimed, not only by peasants with acquired lands, but also by those individuals or legal entities whose land was in the right of use. For a transition to household cut plots, a decision of the rural assembly by a number of $2 / 3$ votes of peasants who had the right to participate in the meeting was considered sufficient (Part 4, Article 1). It was this Article that was the spearhead, as A. Kofod noted, which was aimed at the destruction of the community ${ }^{11}$.

11 Зырянов П.Н. Крестьянская община Европейской России: 1907-1914. М. : МГУ, 1992. 286 c. 
So, the Decree of November 9, 1906 opened a real opportunity for individuals and their families to stand out from the community, to obtain their share in personal property, even if the community objected to such an operation. The very fact of the emergence of an alternative between public and personal land tenure testified, at least in the area of land relations, that Russia had firmly defined its vector - the orientation towards integrated European values.

Subsequently, a serie of regulations made a number of additions and explanations to the voiced articles of the Decree. Thus, by the decision of the Senate of September 23, 1883, supplemented on February 17, 1907, women were made equal in rights with their male homeowners. However, irrespective of the gender of the homeowner, it was considered unlawful to acquire part of the peasant's allotment into personal property. From August 31, 1907 the Ministry of Internal Affairs, declared the inadmissibility of such steps, since "the transition to personal ownership of allotment land is accompanied by a withdrawal from the community" $"$. In short, the land was allowed to be acquired on the right of personal property in the full volume of the existing allotment, and not individual parts of it.

Authorized authorities dedicated much of explanatory work to clarifying the essence and contents of regulations of acquiring the allotment of land into personal ownership by homeowner's family. Thus, the Circular of the Ministry of Internal Affairs of June 6, 1907 prevented the right of the lateral relatives of the homeowner to demand the transfer of their share of allotted land into personal property, unless they achieved legal family distribution and became its independent users. The circular also expanded the ownership powers of the owner of the estate. It was only by his consent that it was allowed to acquire the land into the personal property of non-detached family members who resided with the homeowner.

In the same way, on July 7, 1907, the Ministry of the Interior Affairs spoke about the peculiarities of individuals who claimed the status of a landowner. It recognized only the homeowner-ancestor, who on the personal property right used, owned and disposed of plots from public land acquired by individual owners, as well as of yard allotments granted to peasants by Local Regulations on February 19, 1861, and estates in public land tenure. It was the homeowner who owned the personal property right he disposed of at his own discretion, regardless of the collegial or individual opinion of the rest of the family members ${ }^{13}$.

12 Закон 9 ноября 1906 года о выходе из общины, с разъяснениями. М. : Юристъ, 1908. $85 \mathrm{c}$.

${ }^{13}$ Там само. 
In spite of the government's attempts to decisively restrict public ownership by legal means by granting legal advantages to the land property allocated from the personal property of the secular land, the provisions of Articles 13 and 135 of the General Regulations on the Peasants for the Use of Local Customs in legal disputes on the Inheritance of Peasant property were not reconsidered. However, the court was to establish the reality of the existence of a custom. Otherwise, the lawsuit was conducted on the basis of general civil laws (MIA Circular No. 70 of December 9, 1906) ${ }^{14}$.

\section{Decree of November 9,1906 and the provisions of February 19, 1861 in terms of comparative law}

Analyzing the Decree of 9 November 1906 as well as explanations and additions to it, we find it necessary to emphasize existent discrepancies between the its regulations and the Regulations of February 19, 1861 This need arose in order to objectively and impartially rethink the contents of the document, which, in concept, was only to disclose and supplement the known Art. 36 of the General Regulations on Peasants, edited in 1861 (or Article 12 of the General Regulations, published in 1902). There is every reason to claim that by its contents the Decree went far beyond the title of the article. That is what our speculations are based on:

Firstly, comparing the texts of Art. 36 of the General Provisions on Peasants and the Decree of 9 November 1906 one can notice the inconsistency of their contents with each other. Thus, if in the first case there is a mention of the transfer of allotment land to the property only if it was acquired as a result of the purchase, and the sum for carrying out this operation was to be collected from all members of the community by distribution, then in the second case it concerns all allotment land irrespective of the method of their acquisition;

Secondly, the Decree takes into account not the fate of the individual homeowner's participation in the acquisition of land, as provided for in Art. 36, but only actual use without taking into consideration the changes in the size of the plot over the time of transition to redemption until the cancellation of redemption payments. In an other words, the basis of the acquisition of land ownership and the size of the plot was not the contributions of members of the community made in the form of redemption debt, but only a secular distribution. The famous land law researcher of Russia F. Samarin drew attention to this legal collision. If, for many years, a homeowner made payments for the plots of land of several audit souls, members of his family, and their number diminished for some reasons upon

\footnotetext{
14 Там само.
} 
the acquisition of the whole plot as entire property, he had to repay the land price of the lost audit souls ${ }^{15}$;

Thirdly, the General Regulations on Peasants of February 19, 1861 made it possible for an individual member of the rural community to demand for themselves only the allotment of land, while under the Decree of November 9, 1906, the allotment was to be preceded by the acquisition of land plots into the personal property of the homeowner. The fundamental difference between them was that according to Art. 36 of the General Regulations, the allotted land continued to be in public domain, while under the Decree the allotment land was transferred to the individual homeowner as full personal property on condition of its separation in kind from the secular land;

Fourthly, Art. 36 provided for monetary compensation to the peasant in case of inconvenience or inability to make the separation. Under the rules of the Decree of 9 November 1906, the community was obliged to satisfy the homeowner's demand to withdraw from the community, and to acquire land in private ownership. In case the rural assembly did not want to fulfill the requirement, the land transfer was forced by administrative order. Monetary compensation was paid only if the community could not satisfy the homeowner's request for the allocation of land to one place. However, if the allocation coincided with the general redistribution of land, the community was deprived of the right to replace it with cash payments;

Fifthly, a deep division occurred during the legalization of one of the subjects of property rights for allotments. If the Regulations of the Peasant Reform referred to family property (Articles 93, 98 of the Little Russian Regulations; Article 129 on Redemption Regulations), it was already denied in the Decree of November 9, 1906. The new legal structure - personal land ownership - became standardized. Family property became a legal relic. Researchers are inclined to believe that by changing the wording of this provision, the Decree cancelled a serie of explanations and legal interpretations made by the Senate's departments during $1880-1890^{16}$.

Therefore, contrary to the position declared by the head of the state during the signing of the Decree of November 9, 1906, on the unshakability of the fundamental principles of the Regulations on February 19, 1861, we have foundations to argue that he had gone far beyond the provisions of the Reformed Legislation by the contents and nature of the legislative measure. A comparative correlation of just one Art. 36 of the General Regulation on the

\footnotetext{
${ }^{15}$ Самарин Федор. Указ 9-го ноября 1906 года и Положение 19-го февраля 1861 года. М. : Печатня А. И. Снегиревой, 1908. 16 с.

16 Ламздорф П.К. Высочайший Указ 9 ноября 1906 года и семейная собственность у крестьян. СПб. : Сенатская типография, 1909. 27 с.
} 
peasants with the contents of the Decree testifies to the clear but not advertised intention of the authorities of the Russian Empire to lay the legal foundations for removing obstacles to the rural homeowners in securing the land in personal property. The validity of the imperial act extended to the territories of those provinces in which the public character of land ownership prevailed. The western provinces of Russia, including Podolsk and Volyn gubernias with yard-hereditary system of land tenure, were not subject to the Decree of November 6, 1906. With the elimination of redemption payments on January 1, 1907, the owners of these provinces automatically acquired the status of owners of allotment lands.

The Organizing and Coordinating Center responsible for the implementation of the land reform provisions was designated the General Directorate of Land Management and Bakery (hereinafter referred to as CDLM). The Land Management Committee was established within the management; it was in charge of the activities of county and provincial land management commissions. According to the researchers, it was they which were given the role of active leaders of reformist ideology in places ${ }^{17}$. According to Art. 4 of the first Decree "On Land Management Commissions" of March 4, 1906, they were in charge of issues related to the relocation of peasants to vacant lands: assisting rural communities in using the best experience in allotment land cultivation; on a contractual basis implementating the layout of the stripland; dividing large rural communities into smaller territorial units.

Under the "Regulations on Land Management" of May 29, 1911 the composition of the commission expanded. It included one representative of the judiciary and a parish elected by the peasants of the country case was considered in ${ }^{18}$. Article 100 laid down the conditions for recognizing the legitimacy of decisions of county and provincial land management commissions. It was only with the obligatory participation in the meeting of its permanent member or his deputy, a member of the district court and one of the elected representatives from the Zemstvo or from the peasants the decision of the land management commission was legitimized. The legislator considered such a representation sufficient to minimize the level of wrongful decisions.

The county land management commission was headed by the county leader of the nobility, its members were representatives of similar instances -

\footnotetext{
17 Климин И.И. Столыпинская аграрная реформа и становление крестьянсобственников в России. СПб. : Клио, 2002. 348 с.

${ }^{18}$ Положение о землеустройстве. Полн. собр. законов. Собр. 3. Спб. : Государственная типография, 1914. Т. XXX1. 1914. № 35370.
} 
however, of the county level. Apart from officials appointed to the commission in accordance with their official duties, about half of its members were elected. The representative status in the commission was held by three representatives from the county Zemstvo assembly and three peasants, included by lot from the candidates elected by the village assemblies ${ }^{19}$.

Undoubtedly, the main role in the activities of the land comissions was played by its permanent member, who worked on a constant basis and was responsible for land-arranging work in places. The permanent members of the provincial committees were included in them from 1912 and prior to that time their duties were performed by persons from the number of the oldest officials appointed by CDLM. The candidates for this position in the county commissions were proposed by the local authorities and approved by the Head Office. They were given the following requirements: to have higher education, professional training, experience in land management or peasant affairs management and knowledge of the area.

As we can see, the forming of land management commissions was based on the principle of including in their composition all officials with competence, in one way or another connected with the sphere of agriculture, land relations, including representatives of the peasantry as users of the land granted in the allotment. The peasants were included in the commission for the purpose of presenting their own interests and preventing violations of rights of their stratum.

The land management commissions were called on to streamline land plots of homeowners, who decided to get rid of public land ownership and become their owners. However, the fact of the withdrawal from the community and the acquisition of land did not yet guarantee the mobilization of all scattered lanes into one field. In short, the former public lands, located at a considerable distance from each other, partly due to the possessions of individuals, societies and individual communities, were permanently assigned to the persons to whom the right of ownership of the allotment lands on the basis of personal property was assigned. In this case, the owner lost legal dependence on the community, but continued to be in close land contact with it. Only the Law of June 14, 1910 allowed to collect all strips in one field, that is, to take them to household cuts. As neither the legislation nor the community knew such kinds of land tenure before, the responsibility for their widest possible implementation also rested with the land management commissions ${ }^{20}$.

19 Климин И. И. Столыпинская аграрная реформа и становление крестьян-собственников в России. СПб. : Клио, 2002. 348 с.

${ }^{20}$ Антошкин С. Н. Столыпинская аграрная реформа : [лекция]. М. : МЮИ, 1999. 21 с. 
CDLM as a coordinating and directing institution developed guidelines for local land management commission and recommendations for their use in practice. Land management was recognized as "an operation aimed at changing existing land relations, changing existing forms of land tenure, if it is caused by public expediency and is carried out with a greater or lesser participation of public authorities" 21 .

In another instruction, the Main Directorate defined the contents of land management in the context of land reform provisions. Land management works were divided into two types - single and group ones. The first kind can be called the final form of land management, while the second the preparation for it. The first one included such works as the allocation of acquired lands of individual homeowners from the community to cutting household or farm; distribution (separation) of individual settlements into household cuts or farms. The instruction attributed to group land management such types of land management works that were carried out with the whole group of land tenures, without their allocation to farms and household cuts at the time of the land management itself ${ }^{22}$.

In another instruction, the Main Directorate explained to the provincial and county commissions how household cuts and farms should be interpreted, and what were differences between them. In its interpretation the farm was considered to be a plot of land on which all lands necessary for farming: pastures, arable land, hayfields, farmsteads, water sources were reduced to one place. In the absence of the estate, the land was called a household cut. In addition, if they tried to reduce the arable land to one compact array, then all other lands (hayfields, pastures, forests) could be removed to their household cuts without any connection with arable land ${ }^{23}$. "Given that the most perfect type of land arrangement is a farmstead - quoted paragraph 5 of the Circular of March 21, 1908 - it is necessary to seek a breakdown of the Article into farm plots and only in cases where water supply or other local conditions do not allow to use this Article for sale to farms, it is possible to stop at the arrangement of settlement with the split of the field ground into household cuts or at the sale of the land by household cuts without eviction" 24 .

${ }^{21}$ Хауке О. Русское землеустроительное законодательство. М. : Типолитография, 1910. 157 с. (Выпуск 1).

22 Обзор деятельности Главного управления Землеустройства и Земледелия за 1910 г. СПб. : Тип. В. Ф. Киршбаума, 1911. 380 с.

23 Там само.

24 Державний архів Житомирської області. Ф. 226. Волынская губернская землеустроительная комиссия. Оп. 1. Спр. 776. С циркулярами и циркулярными распоряжениями Главного управления землеустройства и земледелия. Арк. 87-91. Циркуляр комитета по землеустроительным делам от 21 марта 1908 г. № 10. 191 арк. 
On March 19, 1909, the Land Management Committee of the State Agrarian Policy approved, with the signatures of the heads of the central departments, namely ministers or their deputies, "Temporary Rules for Land Management of Entire Rural Communities". Article 27 of the Provisional Rules filled the legislative gap which was not regulated by the Decree of November 9, 1906. It regulated the order of withdrawal of part of the homeowners from the rural community with public land use. The act sanctioned the possibility of allocating in nature the share of the land jointly owned by them, with or without eviction, only provided that a decision was taken by the rural assembly with the participation and consent of all homeowners, candidates for the separation from the community ${ }^{25}$. So, the Rules made it possible for peasants, and first of all, from the number of the poor members of the community in public land use to start farming on privately owned land at a concerted effort.

In a subsequent act, namely by the Decree of November 15, 1906, Nicholas II legalized the right of all categories of peasants who acquired land into personal property and, by decision of the village assemblies, made land allotment in kind outside the community, to get a loan the secured by personal holdings. The subjects of land ownership, such as rural communities, peasant societies, individual owners of suburban areas, as well as those homeowners who allocated their holdings from the public domain, fell into the sphere of regulation of contractual relations (Article 1). In a separate line in the Decree, the Emperor prescribed the right of the Little Russian Cossacks to obtain loans secured by hereditary land estates. However, the restrictions on the Cossack lands existing in the disposal order were not completely cancelled. We are speaking about the possibility of transferring lands with the status of personal property to be mortgaged only to a clearly defined bank - Peasant Land. Commercial banks were not allowed to make transactions with the mortgaged immovables of the Little Russian Cossacks ${ }^{26}$.

In connection with the events of the bourgeois-democratic revolution of 1905-1907 GG and the introduction of the constitutional monarchy in the country, the law-making process in the Russian Empire became more democratic on the one hand and much more complicated on the other. According to Art. 86 of the Basic State Laws, which outlines the procedure for adopting legislative acts, "no new law can be enforced without

25 Там само. Спр. 56. Арк. 85-91. Временные правила о землеустройстве целых сельских обществ от 19 марта 1909 г.

${ }^{26}$ Именной Высочайший Указ Правительствующему Сенату 15 ноября 1906 года. Как могут крестьяне и казаки заложить свои надельные и казачьи земли и для какой надобности разрешается этот залог. Полтава : Типолитография торгового дома И. Фришберг и С. Зорохович, 1907. 38 с. 
the approval of the State Council, the State Duma and that of the Emperor"27. Issued, as well as 7 of other laws of the agrarian complex, with references to Art. 87 in an extraordinary manner between the dissolution of the first and the convening of the second State Duma (July 8, 1906 - February 19, 1907) ${ }^{28}$, the Decree of the Government Senate "On Amendments to some Resolutions of the Present Law Concerning Peasant Land Tenure and Land Use" was to be submitted to the State Duma within two months after its resumption of activity. The government held to the mentioned norm and introduced the bill for discussion on time. Given the need to consider one of the most important land laws, the deputies began discussing the Decree on October 23, 1908 and tried to approve the final decision during 21 meetings of the General Assembly of the State Duma. The document became an object of the six-month discussions at the meetings of the main representative body of the state. Almost 500 speakers took part in the discussion ${ }^{29}$. Only on the last day of the discussion of the Law of November 9, 1906, more than 40 peasants from different regions of Russia participated in the debate. The speakers included peasants' deputies from all Ukrainian provinces, the overwhelming majority of whom supported the Decree and the provisions on the transfer of land from public land ownership to the peasant's personal property. "The peasant needs land, it is necessary to give it to the peasant both having little land and no land, but the peasant needs to get the land as his property", - said from the rostrum a deputy from Chernihiv A. Bazilevich ${ }^{30}$, whose words were consonant to the speeches of the absolute majority of Ukrainian peasant delegates. An understandable clear commitment to private land ownership, including a large one, according to the deputy V. Kuzmin-Karavaev, was manifested by "almost unanimously by the landowners of the Polish Kingdom and Western Territories" ${ }^{\prime 3}$. As we can see, the existing social differentiation between landlords and peasants did not prevent the development of a common position on the need to eliminate public land ownership and to transfer of allotment land to the personal property of the persons who worked on it.

27 Законодательные акты переходного времени, 1904-1908 гг. СПб. : Тов-тво по изданию новых законов, 1909. 982 с.

28 Дякин В.С. Черезвычайное указное законодательство в России (1906-1914). Был ли шанс у Столыпина? : сборник статей. СПб. : ЛИСС, 2002. С. 120-148.

29 Аврех А.Я. П.А. Столыпин и судьбы реформы в России. М. : Политиздат, 1991. $286 \mathrm{c}$

30 Герье В. Второе раскрепощение: общие прения по Указу 9 ноября 1906 года в Государственной Думе и Государственном Совете. М.: Печатня С.П. Яковлева, 1911. $232 \mathrm{c}$.

${ }^{31}$ Кузьмин-Караваев В.Д. “Революционные выступления” Думы и земельный вопрос. СПб. : Б. в., 1906. 42 с. 
In the midst of the debate around the decree, at the insistence of the government, 56 Article was introduced and voted, which temporarily restricted the purchase of land by 6 soul, higher or decree allotments for one person within one county, where the local Great Russian or Little Russian regulations were applied. In the provinces of Right-Bank Ukraine, the purchase was limited to three farmsteads or three foot plots of indigenous land with their homesteads. The State Duma Land Commission noted that the above mentioned allotment restrictions "amount to the double the size of the higher allotment, by the norms of 1861 , of the average composition of the peasant yard today"32. Domestic researcher D. Selikhov quite reasonably believes that the government's position aimed at preventing the concentration of large land latifundias in one hand could be explained by the reluctance of landowners to obtain in the person of the well-to-do peasant a competitor in the agricultural market.

It was not until May 8, 1909 that the decree was approved and transmitted to the General Assembly of the State Council, which elected a special commission of 30 persons to prepare the final conclusion. The latter conducted its work from October 27, 1909 to February 13, 1910, inviting to attend its sittings not only members of the State Council, but also a number of specialists in land relations ${ }^{33}$.

The bill, entitled "Regulations on the Amendments and Supplements to Some Resolutions on Peasant Landownership", received its completed appearance on June 14, 1910. After the signing by Nicholas II of the new Decree, that day the latter was granted the status of a legislative act.

So, from the signing of the Decree on November 9, 1906 until its final approval in accordance with the requirements of the Basic State Laws of 1906, almost four years passed. During the discussion at the General Assembly of the State Council, the Special Commission, and finally, at the third convocation of the State Duma, the original text of the document, which was valid throughout the whole time, was amended and clarified. Among those articles that touched more or less upon the problems of land ownership in various ways, we can distinguish the following ones:

1. From Art. 1 of the Decree of November 9, 1906, recognizing those who had passed on to the court and hereditary possessions of both the community and the individual villages, which had never made any land

32 Селіхов Д.А. Аграрне законодавство царської Росії в Україні епохи капіталізму (друга пол. XIX - поч. XX ст.). : автореф. дис. на здобуття наук. ступеня канд. юр. наук.: спец. 12.00.01. “Теорія та історія держави і права; теорія та історія політичних і правових учень”. Х. : Б. в., 2002. 20 с.

${ }_{33}$ Сидельников С. М. Аграрная реформа Столыпина : [учебное пособие]. М. : МГУ, $1973.335 \mathrm{c}$. 
redistribution since they were allotted, and had not been subdivided for 24 years, the latter were removed from the final text of the Law. For homeowners of such properties the procedure was greatly facilitated. They were allowed to apply to relevant authorities with a request not to fix the fact of acquisition of the plot, but to prepare documents for ownership of it;

2. If in the first Decree the transfer of communities and villages with hereditary (yard or parcel) land ownership to the ownership in household cut areas was carried out by the decision of $2 / 3$ votes of homeowners with the voting right in the east, then according to the Law of June 14, 1910 it was envisaged to make a decision by a simple of majority votes;

3. In the absence of an ancestor in a family who was separated from the community, the responsibility for identifying the homeowner's personality rested with the village council. If, within a month, the community did not make the appropriate decision, the final version of the law enabled the Zemstvo chief to resolve the dispute by interviewing earlier the voting members of the rural assembly;

4. Introduced Art. 10 is missing in the first nominal Decree. It contained a rule under which owners of land plots and unallocated members of their families were deprived of a portion of publicly owned land, which until recently was distributed on a common ground;

5. To the decree of June 14, 1910 was introduced a rule on the right to dispose of subsoil land on allotment plots allocated to personal property. Article 20 entrusted the development of subsoil in these lands, except for the extraction of clay, sand, peat and rubble stones, with the community. It was the community that continued to be the owner of the subsoil of the lands transferred into the personal property from public lands;

6. The provisions of the two decrees obliged the community to satisfy the homeowner's request for getting allotment plots. However, in case it was impossible or inconvenient for the community to implement it, the latter could satisfy the peasant's interests with money, the amount of which was determined by the assessment of the land management commission. Article 34 of the Decree of June 14, 1910 established an exceptional list of cases in which the separation from the community could not be satisfied with the amount of money. The norm on the requirement of $1 / 5$ of a part of households as an unconditional basis for the community's decision to allocate land from its composition was missing in the Decree of November 9, 1906;

7. Unlike the Decree of November 9, 1906 in the case of intentions to purchase surplus land, a simplified procedure for the land evaluation was established. The Second Decree of June 14, 1910, fixed the rate of the land price. It was now to be determined at the initial average price for one-tenth of the land given to the community, which was subject to redemption payments (Article 12). 
8. According to the first Decree lands in so-called non-communal communities, were to be acquired only into personal property while according to the Law of June 14, 1910, they were to be both acquired and certified. Part of the land acts were issued on the demand of communities or villages, and the other part - on the demand of individual yards.

9. The Decree of June 14, 1910 has no norm of the yard as a legal entity.

Of course, there were other differences between the two imperial decrees, but there were no deep discrepancies and polar differences between them. Some asynchrony can be seen in stylistic references, editorial corrections, terminological clarifications and other non-basic details.

Finally, the Land Management Act and the appendix to Art. 64, entitled "On Land Management Commissions and their Land Measurement Part", dated 29 May 1911, crowned the legislative reform package and was to accelerate land management works in villages both with public and yard use of $^{34}$. Article 3 was the first to recognize the allotment plots of peasants and other rural inhabitants as privately owned lands. The concept of farmstead in this law was completely absent. According to the contents of the law, it was included only for household cut plots.

Article 28 fixed normatively the land use forms that had formed during the development of land relations after the liquidation of serfdom. In addition to public, community, worldly land use, there was also mixed one. The latter included such a kind according to which some members of the community with public land use owned their plots as their personal ownership.

The regulation gave land management commissions broad powers for making the final decision on the withdrawal of peasants from the community. It was they who were allowed to authorize the allotment of land into household cut plots. The allocation of arable land took place on the demand of even one homeowner, if a separate land management commission considered such an action expedient and not harmful to the individual community. Otherwise an identical separation mechanism was applied by the decision of the village assembly if it was desired by the fifth of persons who had the right to vote provided the community did not exceed 250 homeowners. In communities with a greater number of homeowners, 50 votes were sufficient (Article 36).

All types of land tenure, including the parcel of land of private or individual backyard owners, purchased from the Peasant Bank or with its assistance by rural communities and peasant societies with public ownership, came under the validity of this legal act. The Allotment of land was held by

34 Закон о землеустройстве. Полн. собр. законов. Собр. 3. СПб. : Гос. типогр., 1914. T. XXX1. 1914. № 35370 . 
the voluntary agreement of the parties with the compulsory liquidation of (Art. 27). In the absence of the agreement it was done in the compulsory order. The latter case did not exempt the land management commission from the need to "strive for the amicable agreement of the parties" (Article 6).

The law greatly simplified the possibility of withdrawing to household cuts. The documents obtained as a result of this procedure were now considered sufficient to certify land ownership. Writing applications for leaving the community, the appropriate design of their portion of the allotment remained in the past. The peasants of communities in which the land was not divided were considered to be private owners. "The ultimate goal of land management, as defined in the Circular of the Yuzich of July 12, 1907, was to maximize the host approachment to his arable land by agricultural lands as close to the homestead as possible: commissions are to divide land plots offered for sale into separate ones for each yard so that each such area is one solid household cut and that its borders are convenient for farming" 35 .

\section{CONCLUSIONS}

So, realizing the complexity of approving legal norms through the legislative procedure born by the revolutionary events, P. Stolypin passed a number of laws regulating land legal relations by manifest order, by means of a mechanism of emergency legislation. The decree of November 9, 1906, was legitimized only after the dissolution of the State Duma of the first convocation the majority of which consisted of representatives of right-wing political forces. The proposed variant of continuation of the land reform did not suit the left wing of the State Duma either. Only four years later, when the results of the reform became obvious and public opinion was well-prepared, the State Duma of the third convocation, after lengthy discussions, adopted the "Regulation on the Amendment and Supplement of Some Resolutions on Peasant Land Ownership", approved by the Imperial Decree of June 14, 1910.

The ideas of both Decrees (of November 9, 1906 and June 14, 1910) were absolutely identical and were intended to promote the peasant masses' withdrawal from public custody and the securing of allotment of land for the homeowner, not for the family. The laws did not envisage any grounds other than the will of the very subjects of relations, for prohibiting the "privatization" of allotment plots. The procedure for the allocation and acquisition of public land into personal property was prescribed in such a way that those wishing to become owners got the maximum assistance in leaving the community.

35 Державний архів Житомирської області. Ф. 226. Оп. 1. Спр. 3. Арк. 120-128. Циркуляр ГУЗ и 3 от 12 июля 1907 г. 
In the fall of 1906, changes to the land legislation, the government pursued a policy of Bonapartism, waving between the two lights. Calming down the broad circles nobility with allegations about the creative development of the Regulations of February 19, 1861 and the absence of intentions to liquidate public land tenure by force the Stolypin paradigm of the land reform had this very purpose. This is evidenced by our analysis of the contents of the Decrees of November 9, 1906 and July 14, 1910, which confirms the innovative nature of these legislative acts.

\section{SUMMARY}

These are the main stages of Stolypin's agrarian reform, initiated by the Decree of November 9, 1906. This revolutionary provision finally destroyed public land ownership and opened the possibility for members of the community to move out of it and acquire land for private ownership. The very fact of the emergence of an alternative between public and personal land tenure testified that, in the sphere of land relations, the Russian Empire had firmly defined its vector - the orientation towards integrated European values. The validity of the imperial act extended to the territories of those provinces in which the public nature of land ownership prevailed. The western provinces of Russia, including Podil and Volyn with a court-hereditary system of land tenure, were not covered by the Decree of November 6, 1906.

A comparative legal analysis of the Decree of November 9, 1906 and its comparison with the Regulations of February 19, 1861.

\section{REFERENCES}

1. Аврех А. Я. П. А. Столыпин и судьбы реформы в России. М. : Политиздат, $1991.286 \mathrm{c}$.

2. Антошкин С. Н. Столыпинская аграрная реформа : [лекция]. М. : МЮИ, 1999. $21 \mathrm{c.}$

3. Бородин А. П. Реформы во имя России. М. : Вече, 2002. 380 с.

4. Боханов А. Н. Последний царь. М. : Вече, 2006. 512 с.

5. Герье В. Второе раскрепощение: общие прения по Указу 9 ноября 1906 года в Государственной Думе и Государственном Совете. М. : Печатня С. П. Яковлева, 1911. 232 с.

6. Дроздов В. П. Крестьянские законы. Права крестьян на землю. М. : Тип. П. П. Рябушинского, 1910. 39 с.

7. Дякин В. С. Черезвычайное указное законодательство в России (1906-1914). Был ли шанс у Столыпина? : сборник статей. СПб. : ЛИСС, 2002. C. $120-148$.

8. Закон 9 ноября 1906 года о выходе из общины, с разъяснениями. М. : Юристъ, 1908. 85 с. 
9. Законодательные акты переходного времени, 1904-1908 гг. СПб. : Тов-тво по изданию новых законов, 1909. 982 с.

10. Зырянов П. Н. Крестьянская община Европейской России: 19071914. М. : МГУ, 1992. 286 с.

11. Климин И. И. Столыпинская аграрная реформа и становление крестьян-собственников в России. СПб. : Клио, 2002. 348 с.

12. Кузьмин-Караваев В. Д. "Революционные выступления" Думы и земельный вопрос. СПб. : Б. в., 1906. 42 с.

13. Ламздорф П. К. Высочайший Указ 9 ноября 1906 года и семейная собственность у крестьян. СПб. : Сенатская типография, 1909. 27 с.

14. Обзор деятельности Главного управления Землеустройства и Земледелия за 1910 г.г. СПб. : Тип. В. Ф. Киршбаума, 1911. 380 с.

15. Самарин Федор. Указ 9-го ноября 1906 года и Положение 19-го февраля 1861 года. М. : Печатня А. И. Снегиревой, 1908. 16 с.

16. Семенов Е. В. Краткие сведения по русскому земельному праву : пособие [для учеников землемерных училищ]. Псков : Тип. губернского земства. $35 \mathrm{c.}$

17. Сидельников С. М. Аграрная реформа Столыпина : [учебное пособие]. М. : МГУ, 1973. 335 с.

18. Столыпин П. А. Думские речи. М : Знание, 1990. 64 с. (Новое в жизни, науке, технике. Серия “Лекторское мастерство”. № 10).

19. Тютюрмов И. М. Закон 14 июня 1910 года об изменениях и дополнениях некоторых постановлений о крестьянском землевладении с законодательными мотивами и разъяснениями Правительствующего Сената (по 1 сентября 1910 года). - [изд. неоф.] СПб. : Издание юридического книжного магазина И. И. Зубкова под фирмою “Законоведение”, 1911. 181 с.

20. Хауке О. Русское землеустроительное законодательство. М. : Типолитография, 1910. 157 с. (Выпуск 1).

\section{Information about the author:} Zakharchenko P. P.,

Doctor of Laws, Professor at the Department of History of Law and State Law Faculty, Taras Shevchenko National University of Kyiv 60, Volodymyrska str., Kyiv, 01033, Ukraine 
NOTES 
NOTES 
Publishing house "Liha-Pres"

9 Kastelivka str., Lviv, 79012, Ukraine 44 Lubicka str., Torun, 87-100, Poland

Printed by the publishing house "Liha-Pres"

Passed for printing: February 14, 2020. A run of 150 copies. 